Article

\title{
Diagenetic Pore Fluid Evolution and Dolomitization of the Silurian and Devonian Carbonates, Huron Domain of Southwestern Ontario: Petrographic, Geochemical and Fluid Inclusion Evidence
}

\author{
Marco Tortola $^{1, *}$, Ihsan S. Al-Aasm ${ }^{1}(\mathbb{D})$ and Richard Crowe ${ }^{2}$ \\ 1 School of the Environment, University of Windsor, Windsor, ON N9B 3P4, Canada; alaasm@uwindsor.ca \\ 2 Nuclear Waste Management Organization, Toronto, ON M4T 2S3, Canada; rcrowe@nwmo.ca \\ * Correspondence: tortolam@uwindsor.ca
}

Received: 13 November 2019; Accepted: 5 February 2020; Published: 7 February 2020

check for updates

\begin{abstract}
Core samples from two deep boreholes were analyzed for petrographic, stable and Sr isotopes, fluid inclusion microthermometry and major, minor, trace and rare-earth elements (REE) of different types of dolomite in the Silurian and Devonian carbonates of the eastern side of the Michigan Basin provided useful insights into the nature of dolomitization, and the evolution of diagenetic pore fluids in this part of the basin. Petrographic features show that both age groups are characterized by the presence of a pervasive replacive fine-crystalline $(<50 \mu \mathrm{m})$ dolomite matrix (RD1) and pervasive and selective replacive medium crystalline $(>50-100 \mu \mathrm{m})$ dolomite matrix (RD2 and RD3, respectively). In addition to these types, a coarse crystalline ( $>500 \mu \mathrm{m})$ saddle dolomite cement (SD) filling fractures and vugs is observed only in the Silurian rocks. Results from geochemical and fluid inclusion analyses indicate that the diagenesis of Silurian and Devonian formations show variations in terms of the evolution of the diagenetic fluid composition. These fluid systems are: (1) a diagenetic fluid system that affected Silurian carbonates and was altered by salt dissolution post-Silurian time. These carbonates show a negative shift in $\delta^{18} \mathrm{O}$ values (dolomite $\delta^{18} \mathrm{O}$ average: $-6.72 \%$ o VPDB), Sr isotopic composition slightly more radiogenic than coeval seawater (0.7078-0.7087), high temperatures (RD2 and SD dolomite $\mathrm{T}_{\mathrm{h}}$ average: $110^{\circ} \mathrm{C}$ ) and hypersaline signature (RD2 and SD dolomite average salinity: $26.8 \mathrm{wt} . \% \mathrm{NaCl}$ eq.); and (2) a diagenetic fluid system that affected Devonian carbonates, possibly occurred during the Alleghenian orogeny in Carboniferous time and characterized by a less pronounced negative shift in $\delta^{18} \mathrm{O}$ values (dolomite $\delta^{18} \mathrm{O}$ average: $-5.74 \%$ o VPDB), Sr isotopic composition in range with the postulated values for coeval seawater $(0.7078-0.7080)$, lower temperatures (RD2 dolomite $\mathrm{T}_{\mathrm{h}}$ average: $83^{\circ} \mathrm{C}$ ) and less saline signature ( $\mathrm{RD} 2$ dolomite average salinity: $20.8 \mathrm{wt} . \% \mathrm{NaCl}$ eq.).
\end{abstract}

Keywords: dolomitization; Huron Domain; Silurian; Devonian; fluid composition; Michigan Basin

\section{Introduction}

The Michigan Basin has been the subject of several diagenetic studies in the last three decades (e.g., [1-8]). However, very few comprehensive investigations regarding the nature and composition of diagenetic fluids, lateral extent of the diagenetic processes and paragenetic sequence of different types of dolomite within Silurian and Devonian successions in the Huron Domain have been carried out. Most previous studies focused on the Paleozoic carbonate succession in the area were limited in stratigraphic and/or spatial resolution (e.g., [1-4]). In addition, contrasting models have been proposed to explain the fluid flow evolution and migration in the Michigan Basin, such as migration of dolomitizing fluids from the center of the Michigan Basin toward the margins [5] or from the back reef downward through 
Guelph limestones to the center of the Michigan basin (e.g., [6-8]). Numerous diagenetic processes such as dolomitization and Mississippi Valley Type (MVT) mineralization, salt dissolution, precipitation of late-stage cement and oil, and gas generation and migration have influenced the Paleozoic succession in the Michigan Basin [9]. Fractures and faults in carbonate bodies represent preferential pathways for fluids which in turn play a key role in the diagenesis and evolution of host rocks and hydrocarbon reservoirs [5]. The presence of fractures and faults in the Michigan intracratonic Basin represented an important control on the modification of host limestones and mobilization of dolomitizing fluids within the basin [4,10-12].

Coniglio et al. [8] performed a regional study of the Silurian Guelph Formation in southwestern Ontario. In this work, the authors underline how burial diagenesis produced the recrystallization of massive dolomites with homogeneous petrographic characteristics but with different geochemistry. According to their study, initial shallow burial dolomitization occurred due to the isolation of the Michigan Basin during the late Silurian. Isotopic values of $\delta^{13} \mathrm{C}$ and ${ }^{87} \mathrm{Sr} /{ }^{86} \mathrm{Sr}$ suggest a Silurian seawater source. They also recorded a decrease of $\delta^{18} \mathrm{O}$ values in dolomite from the platform to the lower slope which occurred with increasing burial depth. These authors suggested that seawater-derived dolomitizing fluids migrated from the margin toward the basin center with a progressive decrease in terms of the capability of the fluids to dolomitize the down-slope.

Luczaj et al. [13] conducted a study of fluid inclusion analysis in dolomite and calcite of the Middle Devonian Dundee Formation. Their work underlines that the sedimentary fabrics are modified by medium to coarse crystalline dolomite. They suggested that fluids characterized as dense $\mathrm{Na}-\mathrm{Ca}-\mathrm{Mg}-\mathrm{Cl}$ brines interacted with host rock at high temperatures (around 120-150 ${ }^{\circ} \mathrm{C}$ ). They invoked a model involving the transport of fluids and heat from deeper parts of the basin along with major fault and fracture zones systems.

Haeri-Ardakani et al. [5] evaluated diagenesis and fluid flow evolution within Ordovician, Silurian and Devonian carbonate successions in southwestern Ontario. Data from fluid inclusions analysis showed homogenization temperatures of replacive and saddle dolomite and late-stage calcite ranging between $75-145^{\circ} \mathrm{C}$. They suggested the involvement of hydrothermal fluids in replacement and recrystallization of dolomite and calcite cementation to explain homogenization temperatures higher than the peak expected during maximum burial for each interval (60-90 $\left.{ }^{\circ} \mathrm{C}\right)$. Evidence of decreasing values in fluid inclusion homogenization temperatures from the center to the margin of the basin suggests that hydrothermal fluids originated from the center of the Michigan Basin. The authors suggest that the potential source of heat could be related to the buried mid-continental rift (MCR), while the preferential pathways for the migration of diagenetic fluids from the center of the Michigan Basin can be related to the Cambrian sandstones that unconformably overlay the Precambrian basement which could have behaved as regional aquifers [5].

The main purpose of this study was to conduct a thorough investigation of the characteristics and the occurrence of dolomitization within the Devonian and Silurian carbonate formations on the eastern side of the Michigan Basin (Figure 1). Dolomitization processes are examined in terms of dolomite types, distribution and geochemistry using an integrated approach utilizing petrography, multi-elements analysis, stable isotopes, Sr-isotopes and fluid inclusion analyses of rock core samples. Based on geologic, geochemical and petrographic investigations, a relative timing in terms of paragenesis of dolomitization is suggested, as well as relationships between existing regional structures and Devonian and Silurian strata-bound dolomite, nature and composition of mineralizing fluid during diagenesis, and extension of diagenetic events. This study represents an important contribution to the more extensive studies carried out by the Nuclear Waste Management Organization (NWMO) for the characterization of a suitable site to develop a Deep Geologic Repository (DGR) for low- and intermediate-level nuclear waste at the Bruce power station in Kincardine, Ontario. 


\section{Geologic and Tectonic Setting}

The study area is located on the northeastern margin of the Michigan Basin (Figure 1a,b). It represents part of the northwestern flank of the Algonquin Arch that consists of Paleozoic sedimentary rocks that cover the subsurface basement [14]. The thickness of the Paleozoic succession ranges from a maximum of $4800 \mathrm{~m}$ at the center of the Michigan Basin to $850 \mathrm{~m}$ on the flank of the Algonquin Arch where the study area is located [15].

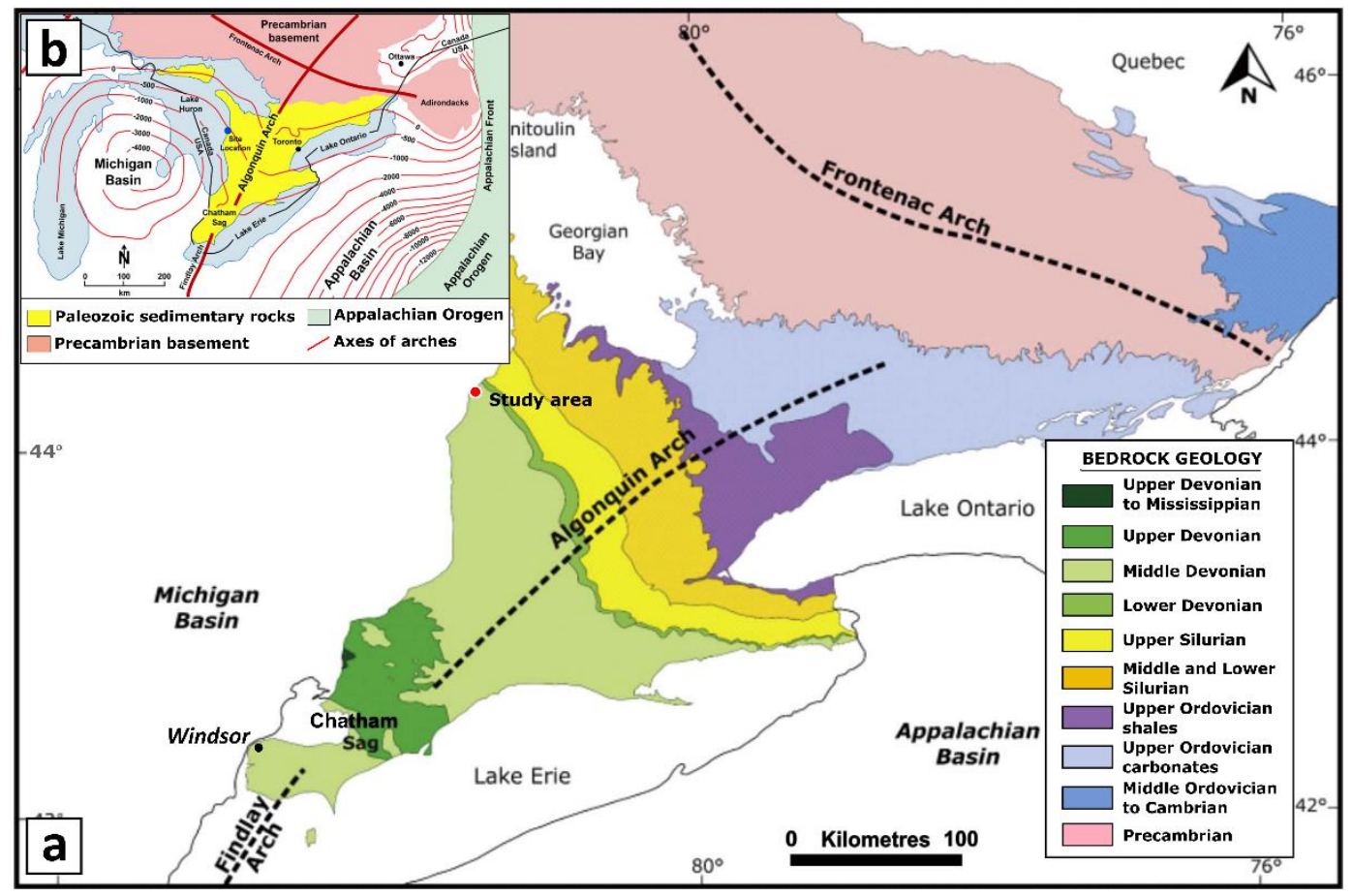

Figure 1. (a) Generalized Paleozoic Bedrock Geology Map of Southern Ontario (modified from OGS [16] and OPG [17]); (b) generalized basement structural contours (meters above the sea level datum) and location of structural arches and basins (modified from OPG [17] and Johnson et al. [18]).

On a regional scale, southern Ontario is located between two major Paleozoic sedimentary basins, the Appalachian Basin to the southeast and Michigan Basin to the west (Figure 1). The Algonquin Arch, which separates the two basins, extends from northeast of the Canadian shield to the southwest near the city of Chatham. Near the Windsor area, another structural high named the Findlay Arch starts extending to the southwest into Michigan and Ohio states [3].

The rifting that separated North America and Africa occurred during Precambrian to Cambrian represents the initial episode of subsidence (approximately $1100 \mathrm{Ma}$ ) and deposition within the Michigan Basin [10]. Thermal subsidence of the Precambrian basement followed this event approximately 580 Ma to 500 Ma because the cooled lithosphere becomes denser [19]. The subsequent and continuous deposition of sediments into the Michigan Basin caused the bending of the basement [20-22]. However, the development of the basin is not only the result of continuous subsidence but represents the result of a series of tectonic events that characterized the Paleozoic [23,24].

The Taconic and Acadian orogenies were a dominant control on the Paleozoic strata of the eastern flank of the Michigan Basin [25]. In fact, during the Taconic Orogeny (Ordovician) a large-scale eastward-tilting of the Laurentian margin governed the disappearance of the concentric depositional geometry of the Michigan Basin with the consequent deposition of Ordovician limestone and overlying shale successions $[24,26,27]$. The regional maximum principal stress at that time was northwesterly oriented the same as the main direction of the thrust motion along the Appalachian tectonic front $[25,28]$. 
Restricted marine conditions occurred during the late Silurian with the consequent deposition of evaporites of the Salina Group [15,18]. In addition, the presence of an unconformity reveals emergent conditions at the end of the Silurian [25]. The Middle Devonian Acadian Orogeny reactivated the Algonquin-Findlay Arch system with the return of the concentric geometry of the Michigan Basin [23]. The Lower and Middle Devonian units are dominated by limestones and dolostones, whereas, the Upper Devonian strata are mostly represented by shales [15].

The Caledonian (Devonian) and Alleghanian (Carboniferous) orogenies played an important role in terms of diagenetic fluid migration [29]. Late Paleozoic sediments have been removed from the entire study area. According to Wang et al. [30], the regional analysis of apatite fission track dating in the center of the Michigan Basin suggests that late to post Alleghenian erosion removed approximately $1000 \mathrm{~m}$ of carbonate successions from the margins and approximately $1500 \mathrm{~m}$ from the center of the basin.

The main characteristics of the Silurian and Devonian stratigraphy in the study area are shown in Figure 2. The Michigan Basin has been characterized by a typical tropical climate during mid to late Silurian [31] whereby shallow water reef complexes started to develop (e.g., Gasport, Lions Head, Fossil Hill and Guelph formations). Moreover, the Michigan Basin has been isolated and becoming an evaporative basin in which alternation of evaporites and carbonates (Salina Group) deposited during the rest of the Silurian [32]. Conversely, during the Middle Devonian, Michigan Basin has been characterized by an extremely arid climate with consequent deposition of shallow intertidal and supratidal lithofacies such as Amherstburg and Lucas formations [33]. 


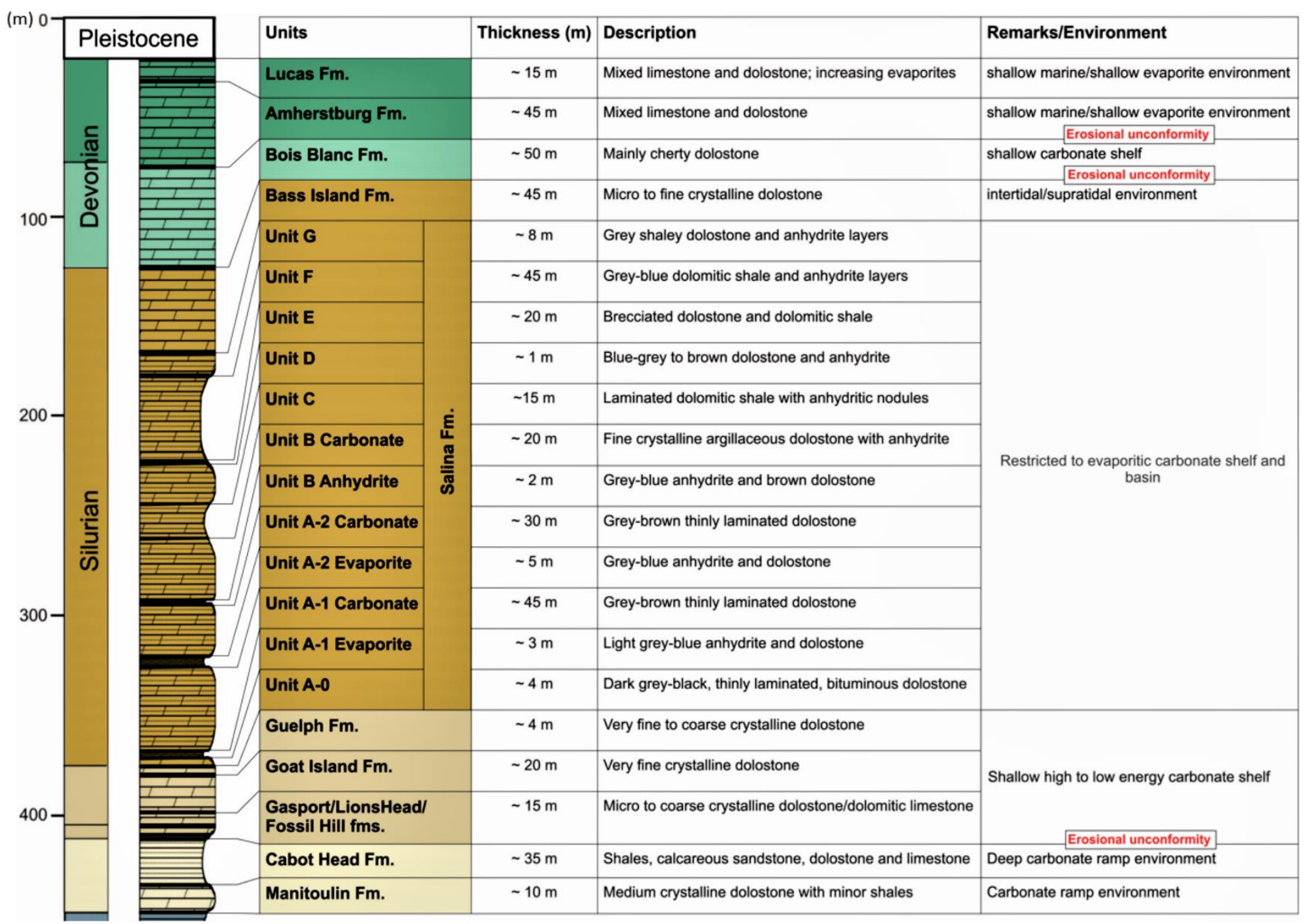

Figure 2. Summary of the Silurian and Devonian stratigraphy in the study area (modified from Johnson et al. [18]; AECOM [25]; Armstrong and Goodman [34]). 


\section{Materials and Methods}

Core samples were collected from the Bruce Nuclear site, the proposed site for a deep geological repository for low- and intermediate-level nuclear waste, from two boreholes DGR1 and DGR8 (Figure 2) [17]. The samples were chosen based on dolomitized and fractured rocks in hand specimens. A summary of sample identification with relative age and depth is reported in Figure 3 and Table 1.

The selected core samples were photographed before making thin sections and wafers for fluid inclusions analysis. Petrographic examination of thin sections $(n=46)$ was performed using a standard petrographic microscope to provide lithofacies types, textural relationships and diagenetic fabric of the studied samples, to establish the paragenetic sequences. Subsequently, all thin sections were examined using cathodoluminescence microscopy (CL) to obtain data regarding the chemistry of the fluids, mineral zonation and diagenetic textures of host rock and fracture filling cement. The equipment used to carry out the cathodoluminescence analysis was a Technosyn Model 8200 MKII with a $12-15 \mathrm{Kv}$ beam and a current intensity of 0.42-0.43 mA (Cambridge Image Technology Ltd., Hatfield, Hertfordshire, UK). The thin sections were also stained using a mixture of Alizarin Red S and potassium ferricyanide dissolved in a dilute solution of hydrochloric acid $[35,36]$ to distinguish between ferroan or non-ferroan phases of calcite and dolomite.

\section{DGR 1}

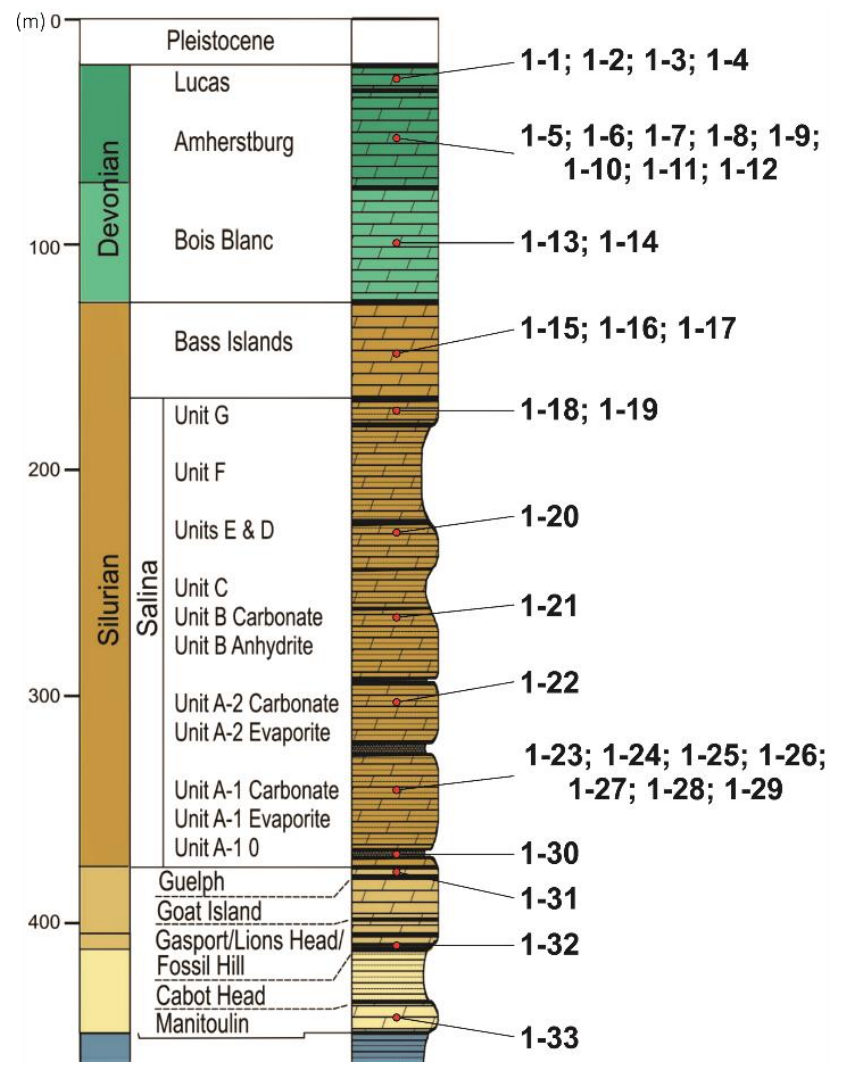

\section{DGR 8}

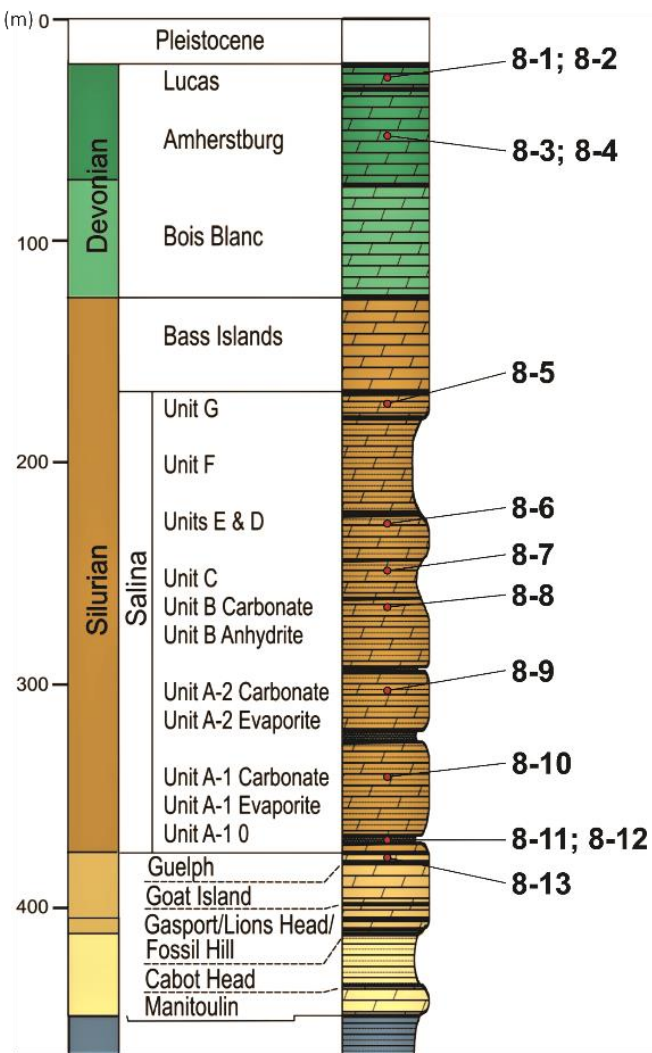

Figure 3. Stratigraphy at the Bruce Nuclear Site and sample locations (modified from AECOM [25]).

A total of forty-three (Silurian) and thirty-three (Devonian) samples were micro-sampled using a microscope-mounted drill assembly for oxygen and carbon isotopic composition from Silurian ( $n=18$ and $n=25)$ and Devonian ( $n=12$ and $n=21)$ specimens for calcitic and dolomitic components, respectively. Each sample was reacted in vacuo with $100 \%$ pure phosphoric acid four $4 \mathrm{~h}$ at $50{ }^{\circ} \mathrm{C}$ and $25{ }^{\circ} \mathrm{C}$ for dolomite and calcite respectively. The $\mathrm{CO}_{2}$ produced during the reaction by the different diagenetic mineral phases was extracted using the method proposed by Al-Aasm et al. [37] 
and measured employing a Delta-Plus mass spectrometer (Thermo Electron Corporation, Bremen, Germany). The delta values of oxygen and carbon isotopes have been reported in per mil (\%o) relative to the PeeDee Belemnite (VPDB) standard and corrected for phosphoric acid fractionation. Precision was better than $0.05 \%$ o for both ${ }^{13} \mathrm{C}$ and ${ }^{18} \mathrm{O}$. Carbon dioxide extraction and isotopic composition measurements were performed at the Stable Isotopes Laboratory, University of Windsor (Windsor, ON, Canada).

Table 1. Lists of samples collected from the boreholes DGR1 and DGR8.

\begin{tabular}{|c|c|c|c|c|}
\hline Cored Sample & Sample Code & Formation & Age & Depth (m) \\
\hline DGR1-CR1 & $1-1$ & Lucas & Devonian & 23.5 \\
\hline DGR1-CR2-(1) & $1-2$ & Lucas & Devonian & 26.25 \\
\hline DGR1-CR2-(2) & $1-3$ & Lucas & Devonian & 26.95 \\
\hline DGR1-CR2-(3) & $1-4$ & Lucas & Devonian & 27.75 \\
\hline DGR1-CR3-(1) & $1-5$ & Amherstburg & Devonian & 31.35 \\
\hline DGR1-CR3-(2) & $1-6$ & Amherstburg & Devonian & 31.85 \\
\hline DGR1-CR5 & $1-7$ & Amherstburg & Devonian & 35.95 \\
\hline DGR1-CR8 & $1-8$ & Amherstburg & Devonian & 42.58 \\
\hline DGR1-CR9 & $1-9$ & Amherstburg & Devonian & 46.4 \\
\hline DGR1-CR10-(1) & $1-10$ & Amherstburg & Devonian & 48.65 \\
\hline DGR1-CR10-(2) & $1-11$ & Amherstburg & Devonian & 49.7 \\
\hline DGR1-CR11 & $1-12$ & Amherstburg & Devonian & 51 \\
\hline DGR1-CR30-(1) & $1-13$ & Bois Blanc & Devonian & 104.05 \\
\hline DGR1-CR30-(2) & $1-14$ & Bois Blanc & Devonian & 105.08 \\
\hline DGR1-CR41 & $1-15$ & Bass Island & Silurian & 128.93 \\
\hline DGR1-CR44 & $1-16$ & Bass Island & Silurian & 133.03 \\
\hline DGR1-CR49 & $1-17$ & Bass Island & Silurian & 142.28 \\
\hline DGR1-CR65 & $1-18$ & Salina-G-Unit & Silurian & 176.13 \\
\hline DGR1-CR66 & $1-19$ & Salina-G-Unit & Silurian & 178 \\
\hline DGR1-CR84 & $1-20$ & Salina-E-Unit & Silurian & 229.32 \\
\hline DGR1-CR104 & $1-21$ & Salina-B-Unit (Carbonate) & Silurian & 289.85 \\
\hline DGR1-CR105 & $1-22$ & Salina- $\mathrm{A}_{2}$-Unit (Carbonate) & Silurian & 294.14 \\
\hline DGR1-CR116-(1) & $1-23$ & Salina- $\mathrm{A}_{1}$-Unit (Carbonate) & Silurian & 326.92 \\
\hline DGR1-CR116-(2) & $1-24$ & Salina- $\mathrm{A}_{1}$-Unit (Carbonate) & Silurian & 328.17 \\
\hline DGR1-CR117 & $1-25$ & Salina- $\mathrm{A}_{1}$-Unit (Carbonate) & Silurian & 329.97 \\
\hline DGR1-CR118 & $1-26$ & Salina- $\mathrm{A}_{1}$-Unit (Carbonate) & Silurian & 333.48 \\
\hline DGR1-CR119 & $1-27$ & Salina- $\mathrm{A}_{1}$-Unit (Carbonate) & Silurian & 337.32 \\
\hline DGR1-CR121 & $1-28$ & Salina- $\mathrm{A}_{1}$-Unit (Carbonate) & Silurian & 342.27 \\
\hline DGR1-CR122 & $1-29$ & Salina- $\mathrm{A}_{1}$-Unit (Carbonate) & Silurian & 344.42 \\
\hline DGR1-CR130 & $1-30$ & Salina- $\mathrm{A}_{0}$-Unit & Silurian & 371.27 \\
\hline DGR1-CR133 & $1-31$ & Guelph & Silurian & 378.1 \\
\hline DGR1-CR143 & $1-32$ & Fossil Hill & Silurian & 410.1 \\
\hline DGR1-CR154 & $1-33$ & Manitoulin & Silurian & 440.92 \\
\hline DGR8-CR10 & $8-1$ & Lucas & Devonian & 22.71 \\
\hline DGR8-CR17 & $8-2$ & Lucas & Devonian & 43.46 \\
\hline DGR8-CR18 & $8-3$ & Amherstburg & Devonian & 48.61 \\
\hline DGR8-CR22 & $8-4$ & Amherstburg & Devonian & 59.06 \\
\hline DGR8-CR64 & $8-5$ & Salina-G-Unit & Silurian & 182.06 \\
\hline DGR8-CR90 & $8-6$ & Salina-E-Unit & Silurian & 238.91 \\
\hline DGR8-CR100 & $8-7$ & Salina-C-Unit & Silurian & 265.46 \\
\hline DGR8-CR110 & $8-8$ & Salina-B-Unit (Carbonate) & Silurian & 295.91 \\
\hline DGR8-CR116 & $8-9$ & Salina- $\mathrm{A}_{2}$-Unit (Carbonate) & Silurian & 313.31 \\
\hline DGR8-CR122 & $8-10$ & Salina- $\mathrm{A}_{1}$-Unit (Carbonate) & Silurian & 332.26 \\
\hline DGR8-CR137 & $8-11$ & Salina- $\mathrm{A}_{0}$-Unit & Silurian & 377.21 \\
\hline DGR8-CR137 & $8-12$ & Salina- $\mathrm{A}_{0}$-Unit & Silurian & 378.75 \\
\hline DGR8-CR139 & $8-13$ & Guelph & Silurian & 382.4 \\
\hline
\end{tabular}


Around $10-50 \mathrm{mg}$ of powdered samples $(\mathrm{n}=22)$ were extracted to determine the Sr isotopic composition using a microscope-drill assembly, to be subsequently reacted with $2.5 \mathrm{~N} \mathrm{HCl}$ for $24 \mathrm{~h}$ at room temperature. To avoid Strontium contamination from pore salts produced by drying the samples, they were washed twice using Milli-Q water. To measure the strontium isotope ratio in each sample, an automated Finnigan MAT 261TM mass spectrometer was employed, performing all the analysis in the static multicollector mode with Re filaments and normalizing ${ }^{87} \mathrm{Sr} /{ }^{86} \mathrm{Sr}$ ratios to ${ }^{87} \mathrm{Sr} /{ }^{86} \mathrm{Sr}=8.375209$. The mean standard error of the static multicollector was 0.00003 for NBS-987. These analyses were done at the University of Bochum, Bochum, Germany.

A thorough petrographic investigation of doubly polished thin sections was performed to identify and classify fluid inclusions trapped in diagenetic minerals. Measured ice-melting temperatures (Tmice) are reported as wt.\% $\mathrm{NaCl}$ eq. using the relationship of Hall et al. [38] and Bodnar [39]. Detailed petrography was performed to determine the type of inclusions (primary or secondary/pseudosecondary) following the criteria proposed by Roedder [40]. For this study, attention was focused on primary liquid-vapor inclusion assemblages only. The microthermometric measurements were performed at the University of Windsor (Windsor, ON, Canada) employing a Linkam TH600 heating-freezing stage, coupled with the Olympus BX60. The device calibration was achieved using synthetic pure water and $\mathrm{CO}_{2}$ inclusions as standard. Microthermometric analyses were completed on 126 primary fluid inclusions in selected carbonate samples from the Silurian $(n=85)$ and Devonian $(n=41)$ successions including pervasive replacive medium crystalline dolomite (RD2; $\mathrm{n}=22$ and $\mathrm{n}=17$ for Silurian and Devonian samples, respectively), saddle dolomite (SD; $\mathrm{n}=31$; observed in Silurian samples only) and late fracture-filling blocky calcite cement (BKC; $\mathrm{n}=32$ and $\mathrm{n}=24$ from Silurian and Devonian samples, respectively). Homogenization temperatures $\left(\mathrm{T}_{\mathrm{h}}\right)$ and ice-melting temperatures (Tmice) were measured with a precision of $\pm 1^{\circ} \mathrm{C}$ and $\pm 0.1{ }^{\circ} \mathrm{C}$, respectively. Heating measurements were performed before freezing to avoid possible stretching of the inclusions during freezing [41].

Major, minor, trace and rare earth elements (REE) analyses were performed using inductively coupled plasma spectroscopy (ICP-MS) technique. Around 50-100 mg of powdered carbonate samples from different calcite and dolomite phases were digested utilizing 5\% v/v acetic acid. Measurements were carried employing an Agilent 8800 inductively coupled mass spectrometer at the University of Waterloo (Waterloo, ON, Canada). All results are reported in part per million (ppm). The REEs' results obtained from ICP-MS analysis were normalized to PAAS (Post-Archean Australian Shales [42]). Rare-earth element anomalies such as $\mathrm{Ce}_{\mathrm{SN}}\left[\left(\mathrm{Ce} / \mathrm{Ce}^{*}\right)_{\mathrm{SN}}=\mathrm{Ce}_{\mathrm{SN}} /\left(0.5 \mathrm{La} \mathrm{SN}+0.5 \operatorname{Pr}_{\mathrm{SN}}\right)\right], \mathrm{La}_{\mathrm{SN}}\left[\left(\operatorname{Pr}_{\mathrm{Pr}} \mathrm{Pr}_{\mathrm{SN}}\right.\right.$ $\left.\left.=\operatorname{Pr}_{\mathrm{SN}} / 0.5 \mathrm{Ce}_{\mathrm{SN}}+0.5 \mathrm{Nd}_{\mathrm{SN}}\right)\right], \mathrm{Eu}_{\mathrm{SN}}\left[\left(\mathrm{Eu} / \mathrm{Eu}^{*}\right)_{\mathrm{SN}}=\mathrm{Eu}_{\mathrm{SN}} /\left(0.5 \mathrm{Sm}_{\mathrm{SN}}+0.5 \mathrm{Gd}_{\mathrm{SN}}\right)\right]$, and $\mathrm{Gd}_{\mathrm{SN}}\left[\left(\mathrm{Gd} / \mathrm{Gd}^{*}\right)_{\mathrm{SN}}\right.$ $\left.=\mathrm{Gd}_{\mathrm{SN}} /\left(0.33 \mathrm{Sm}_{\mathrm{SN}}+0.67 \mathrm{~Tb}_{\mathrm{SN}}\right)\right]$ were calculated employing the equations proposed by Bau and Dulski [43]. The proportions of LREE (La-Nd) over HREE (Ho-Lu) were calculated via $(\mathrm{La} / \mathrm{Yb})_{\mathrm{SN}}$ ratios as proposed by Kucera et al. [44]. The proportions of MREE (Sm-Dy) was calculated using $(\mathrm{Sm} / \mathrm{La})_{\mathrm{SN}}$ and $(\mathrm{Sm} / \mathrm{Yb})_{\mathrm{SN}}$ ratios [45] over LREE and HREE, respectively.

\section{Results}

\subsection{Petrography of Silurian Formations}

The diagenetic history of the Silurian formations includes processes such as dolomitization mechanical and chemical compaction, fracturing, dissolution, silicification, and calcite and evaporite cementation. The diagenetic processes above are described in Tortola [46], on which this paper is largely based.

\subsubsection{Dolomitization}

Four types of dolomite occur in the Silurian formations (Figure 4) and are classified following the criteria proposed by Sibley and Gregg [47]. These include including three types of replacive matrix dolomite and one of dolomite cement. These are a pervasive replacive micro to fine crystalline 
$(<50 \mu \mathrm{m})$ euhedral to subhedral dolomite matrix (RD1) (Figure 4A); a pervasive replacive medium (>50-100 $\mu \mathrm{m}$ ) euhedral crystalline dolomite matrix (RD2) (Figure 4B), which represent the main constituents of the host rock; and a less abundant selective replacive medium (>50-100 $\mu \mathrm{m})$ euhedral crystalline dolomite matrix (RD3) only observed along dissolution seams in partially dolomitized limestones, usually characterized by cloudy-dark cores and clear rims (Figure 4C). All dolomite types are non-ferroan and show dull red to non-luminescent (RD1 and RD2) and red to bright (RD3) under the CL (Figure 4D,E). In some cases, RD2 shows undulose extinction similar to saddle dolomite (e.g., $[5,48])$ and is characterized by cloudy non-ferroan cores followed by later clear and iron-rich rims (Figure 4B,F). In addition to these types, a coarse crystalline (>500 $\mu \mathrm{m}$ ), ferroan saddle dolomite cement (SD; Figure 4G) filling fractures and vugs are observed, commonly predating late calcite cement (Figure 4E,H) and occasionally evaporite minerals (Figure 4I). Typically, SD is fluid inclusion-rich, zoned with cloudy cores and clear rims, and characterized by curved crystal boundaries.
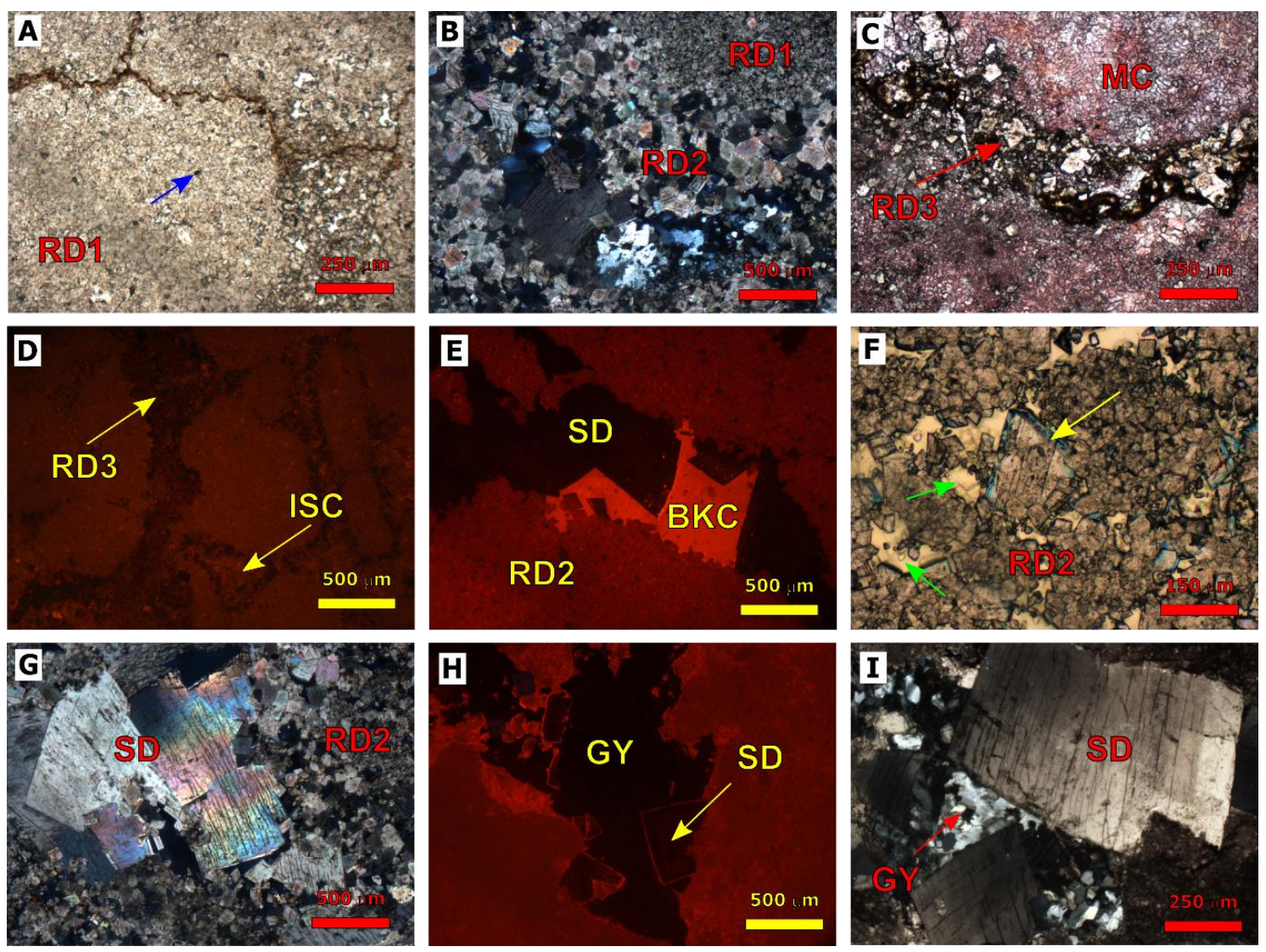

Figure 4. Dolomitization in Silurian formations. (A) Photomicrograph (PPL) of planar-s, pervasive replacive micro to fine crystalline dolomite matrix (RD1). Sample 1-18; Well: DGR1-CR65; depth: $176.13 \mathrm{~m}$. The blue arrow indicates the presence of framboidal pyrite in the matrix; (B) photomicrograph (XPL) of non-planar, pervasive replacive micro to fine crystalline dolomite matrix and planar-e pervasive replacive medium crystalline dolomite matrix (RD2). Sample 1-31; Well: DGR1-CR133; depth: 440.92 m; (C) photomicrograph (PPL-after staining) of planar-e, selective replacive medium crystalline dolomite matrix (RD3) associated with dissolution seams showing cloudy cores and clear rims (red arrow). Undolomitized limestone matrix (MC) shows a pink color after staining. Sample 8-12; well: DGR8-CR137 (2); depth: $378.75 \mathrm{~m}$; (D) CL photomicrograph of isopachous calcite cement (ISC) and selective replacive medium crystalline dolomite matrix (RD3) both showing dully-red luminescence. Note the change from dull to red luminescent of ISC towards the center of the vug. Sample 8-10; well: DGR8-CR122; depth: $332.26 \mathrm{~m}$; (E) CL photomicrograph of bright luminescent blocky calcite cement (BKC) postdating non-luminescent saddle dolomite cement (SD) surrounded by dull-red medium crystalline dolomite 
matrix (RD2). Sample 8-13; Well: DGR8-CR139; Depth: 382.4 m; (F) photomicrograph (PPL-after staining) of planar-e to planar-s, pervasive replacive medium crystalline dolomite matrix (RD2) showing intercrystalline porosity (green arrows) and non-ferroan cores followed by later iron-rich rims (yellow arrow). Sample 1-24; well: DGR1-CR116 (2); depth: $328.17 \mathrm{~m}$; (G) photomicrograph (XPL) of fracture filling saddle dolomite cement (SD) postdating pervasive replacive medium crystalline dolomite matrix (RD2) characterized by distinctive wavy extinction and curved crystal boundaries. Sample 1-31; Well: DGR1-CR133; Depth: 440.92 m. (H) CL photomicrograph of gypsum (GY) postdating non-luminescent with bright rims zoned saddle dolomite (SD). Sample 8-13; Well: DGR8-CR139; depth: 382.4 m; (I) photomicrograph (XPL) of gypsum cement (GY) postdating coarse saddle dolomite cement (SD). Sample 8-9; well: DGR8-CR116; depth: $313.31 \mathrm{~m}$.

\subsubsection{Fracturing}

Three types of fractures are present in the studied formations. Thin randomly oriented hairline fractures $(<0.5 \mathrm{~cm})$ filled with drusy calcite cement $(\mathrm{DC})$ represent the first generation of fractures (Figure 5A). Late wider subhorizontal and subvertical fractures $(0.5-1 \mathrm{~cm})$, both commonly occluded by saddle dolomite, late blocky calcite and evaporite cement representing the second and third generations, respectively (Figure 5B,C). Cross-cutting relationship of the last two generations of fractures shows that cementation took place after the formation of both fractures.
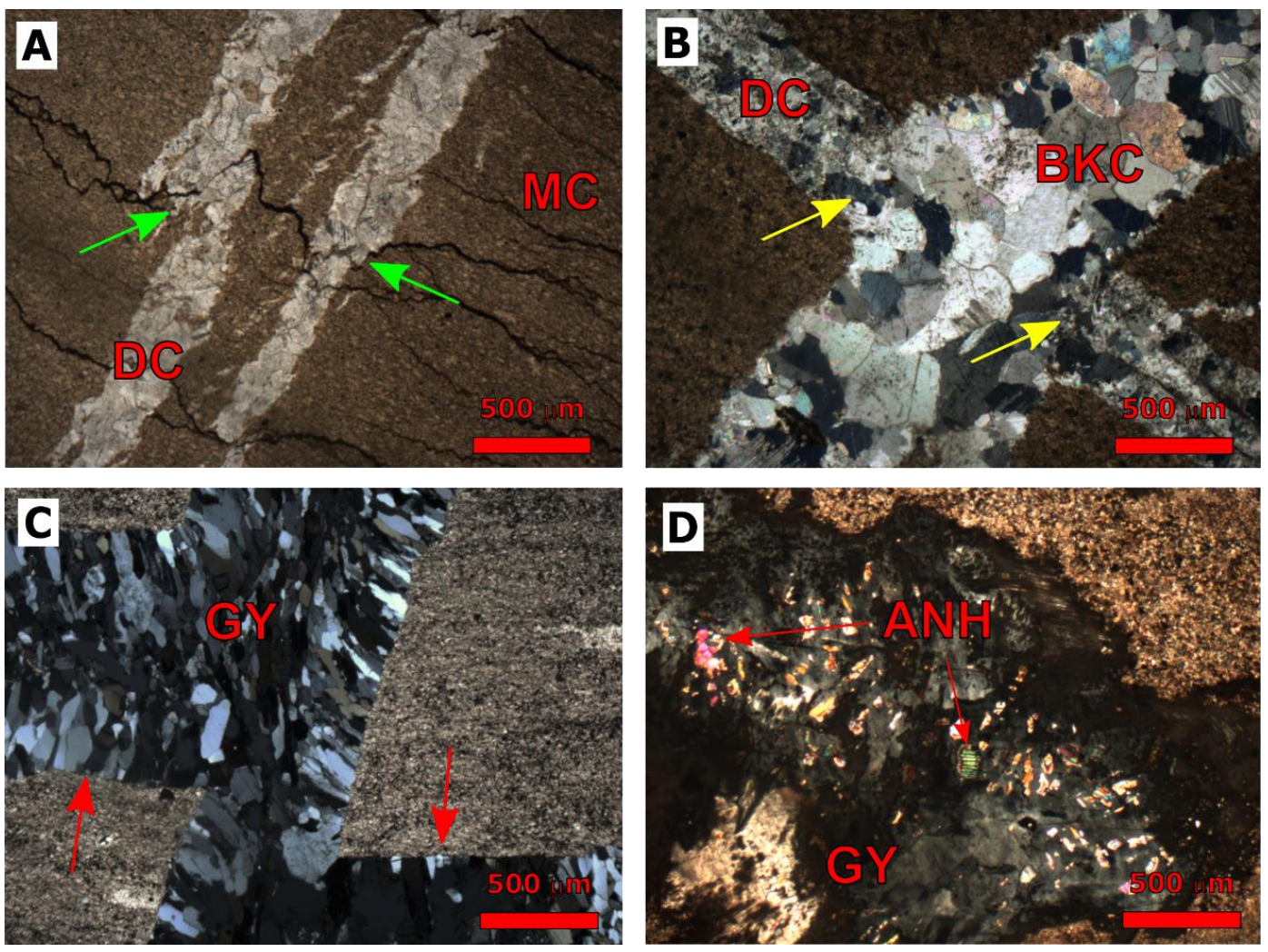

Figure 5. Fracturing in Silurian formations. (A) Photomicrograph (PPL) of multiple stylolites (green arrows) cross-cutting fracture-filling drusy calcite cement (DC). The surrounding matrix is micritic (MC). Sample 1-28; well: DGR1-CR121; depth: 342.27 m; (B) photomicrograph (XPL) of a sub-vertical fracture-filled by blocky calcite cement (BKC) cross-cutting and postdating (yellow arrows) a drusy mosaic calcite cement (DC) filling a randomly oriented fracture. Sample 1-28; well: DGR1-CR121; depth: $342.27 \mathrm{~m}$; (C) photomicrograph (XPL) showing two generations of fractures; the first sub-horizontal (red arrows) displaced by the second sub-vertical, gypsum filled fracture. Sample 1-29; well: DGR1 - CR122; depth: $344.42 \mathrm{~m}$; (D) photomicrograph (XPL) of a fracture filled by gypsum (GY) partially replaced by anhydrite (ANH) showing higher birefringence. Sample 8-7; well: DGR8-CR100; depth: $265.46 \mathrm{~m}$. 


\subsubsection{Calcite Cementation}

Early and late-stage calcite cement (Figure 6) have been distinguished including from early to late: isopachous, syntaxial overgrowth, drusy, and blocky calcite. Undolomitized calcite matrix (MC) from precursor limestone was also recognized (Figures $4 \mathrm{C}$ and $5 \mathrm{~A}$ ). Isopachous calcite cement (ISC) is characterized by cement rims growing around coated grains. It exhibits microcrystalline, bladed texture (Figure 6A) with non-ferroan, dully-red luminescence (Figure 4D) and crystal size ranging from 50 to $100 \mu \mathrm{m}$. Syntaxial calcite overgrowth cement (SXC) forms ferroan, bright-luminescent crystals ranging in size from $100 \mu \mathrm{m}$ up to $>500 \mu \mathrm{m}$, usually around echinoderm fragments (Figure 6B). Void-filling and pore-lining drusy calcite cement (DC) was mainly observed in intergranular and intraskeletal pores, molds and fractures. Common textural features show equant to elongate, anhedral to subhedral crystals ranging in size between 75-250 $\mu \mathrm{m}$ with dimension increasing towards the center of the pore space (Figure 6C). In most cases, DC is ferroan and exhibits dully-red luminescence under CL (Figure 6D).

A late fractures and void-filling blocky calcite cement (BKC) consisting of coarse non-ferroan to ferroan crystal (Figure 6E) ranging in size from $200 \mu \mathrm{m}$ to $>500 \mu \mathrm{m}$, shows zoned red to bright luminescence under CL (Figure 6F) and commonly postdate saddle dolomite cement.

In terms of paragenesis, early calcite cement (ISC, SXC and DC) predated RD1, RD2 and RD3 and predated fracture- and pore-filling saddle dolomite which is postdated by late blocky calcite (BKC) and evaporite (GY and ANH) cement.

\subsubsection{Evaporite Cementation}

Pore and fracture-filling fibrous gypsum (GY)/anhydrite (ANH) cements in the Silurian formations range in size from 50-150 $\mu \mathrm{m}$ (Figures 4I and 5C,D). They are the latest stage diagenetic mineral phases. Both gypsum and anhydrite are only present in samples from the Salina Group Formation, commonly postdating fracture-filling blocky calcite and saddle dolomite cement (Figure 4I).

\subsection{Petrography of Devonian Formations}

\subsubsection{Dolomitization}

Three types of dolomite occur in the Devonian formations (Figure 7), which are characterized by the presence of pervasive replacive micro to fine $(<50 \mu \mathrm{m})$, euhedral to subhedral, crystalline dolomite matrix (RD1) (Figure 7A,B), a pervasive replacive medium $(>50-100 \mu \mathrm{m}$ ) euhedral crystalline dolomite matrix (RD2) (Figure 7B-D), which represent the main constituents of the host dolostone, and a less abundant selective replacive medium $(>50-100 \mu \mathrm{m})$ euhedral crystalline dolomite matrix (RD3 commonly associated with dissolution seams), and usually characterized by cloudy-dark core and clear rims (Figure 7E). All three types of dolomite are non-ferroan and show non-luminescent to dull red (RD1 and RD2) and red to bright red (RD3) under the CL (Figure 7B,F).

A schematic summary of the main features with relative nomenclatures of the main carbonate minerals observed and described for both age groups is presented in Table 2. 

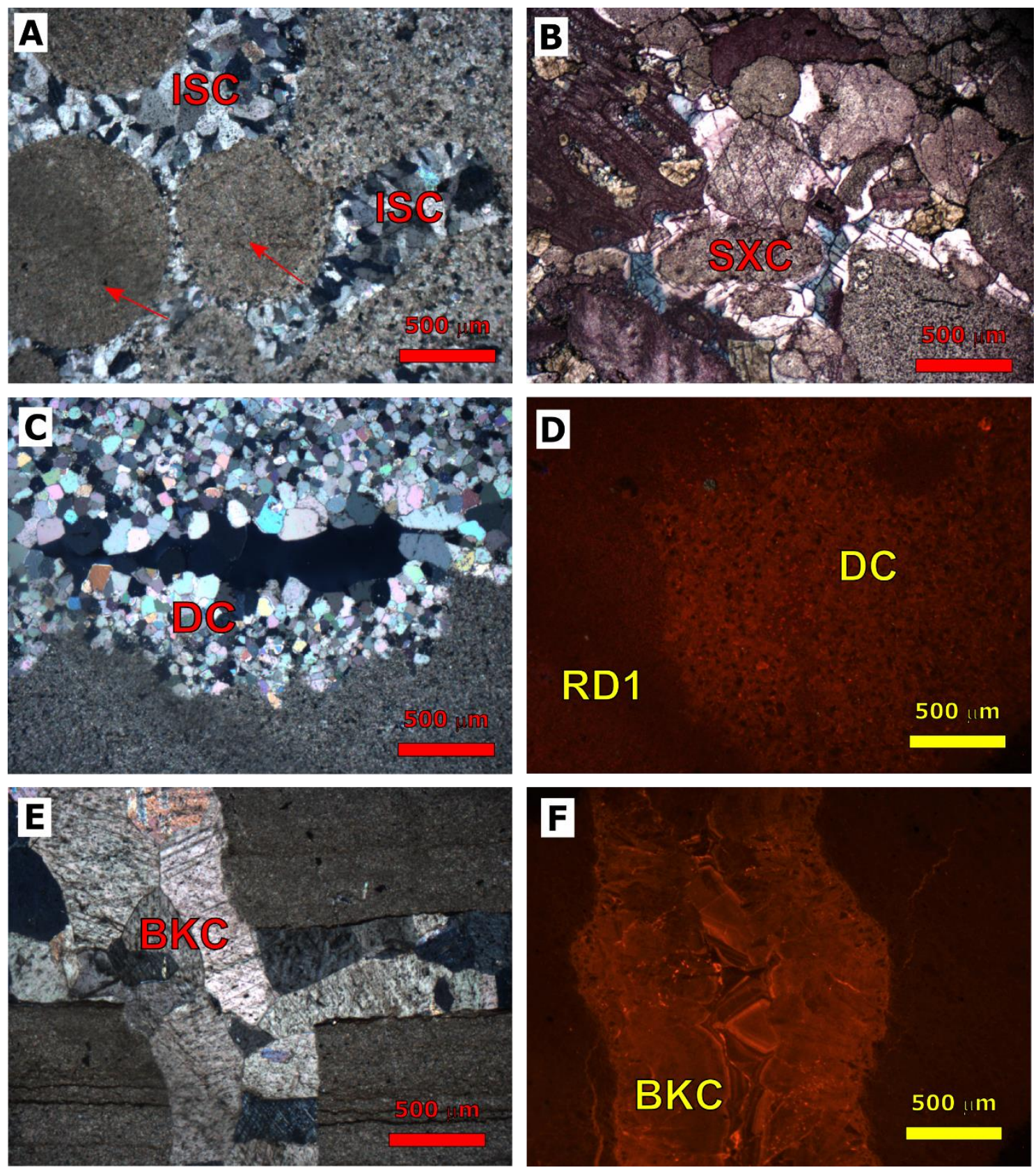

Figure 6. Calcite cementation in Silurian formations. (A) Photomicrograph (XPL) of isopachous calcite cement (ISC) filling interparticle pores in coated grains (red arrows). Sample 8-10; well: DGR8-CR122; depth: $332.26 \mathrm{~m}$; (B) photomicrograph (PPL_after staining) of ferroan syntaxial overgrowth calcite cement (SXC) on crinoidal and echinoid skeletal fragments in a bioclastic grainstone. Sample 1-33; well: DGR1-CR154; depth: 440.92 m; (C) photomicrograph (XPL) of drusy calcite cement (DC) showing increasing crystal sizes towards the center of a vug in a fenestral dolostone. Sample 1-17; well: DGR1-CR49; depth: 142.28 m; (D) CL photomicrograph of pervasive replacive fine crystalline dolomite matrix (RD1) and vug-filling drusy calcite cement (DC) both showing dully-red luminescence. Sample 1-17; well: DGR1-CR49; depth: $142.28 \mathrm{~m}$; (E) photomicrograph (XPL) of a single generation of blocky calcite cement (BKC) filling fractures in a fine crystalline, laminated dolostone. Sample 8-5; well: DGR8-CR64; depth: $182.06 \mathrm{~m}$. (F) CL photomicrograph of fracture-filling, late blocky calcite cement (BKC) showing red to bright zoned luminescence. Sample 1-26; well: DGR1-CR119; depth: $333.48 \mathrm{~m}$. 

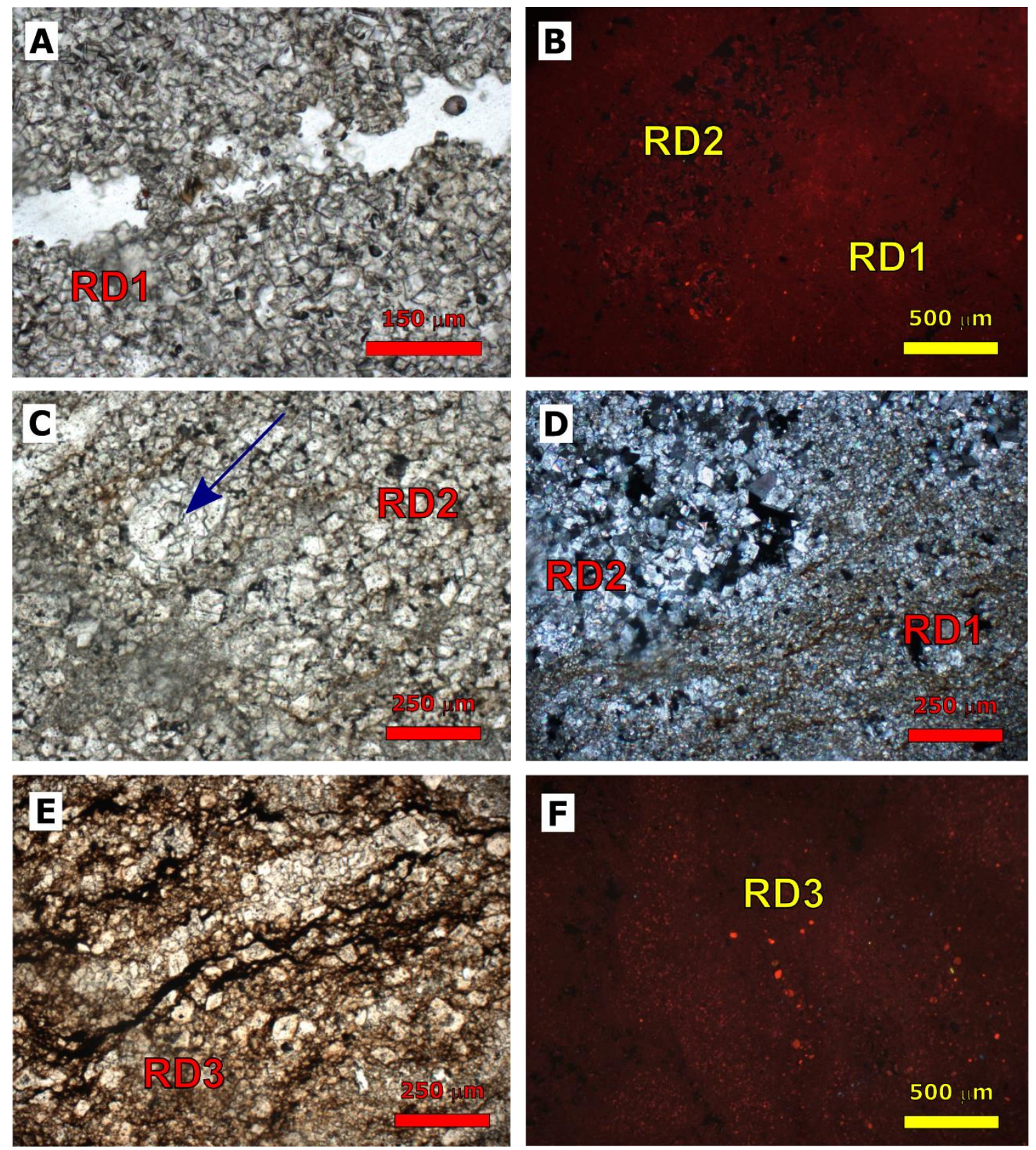

Figure 7. Dolomitization in Devonian formations. (A) Photomicrograph (PPL) of planar-e to planar-s, pervasive replacive micro to fine crystalline dolomite matrix (RD1). Sample 1-1; well: DGR1-CR1; depth: $23.5 \mathrm{~m}$; (B) CL photomicrograph of pervasive replacive, fine-crystalline dolomite matrix (RD1) and pervasive replacive, medium crystalline dolomite matrix (RD2) showing red luminescence. Sample 8-4; well: DGR8-CR22; depth: 59.06 m; (C) photomicrograph (XPL) of planar-e to planar-s, medium crystalline dolomite matrix (RD2) pervasively replacing precursor limestone and partially replacing allochems fragments (blue arrow). Sample 1-4; well: DGR1-CR2 (3); depth: 27.75 m; (D) photomicrograph (XPL) of planar-e to planar-s, pervasive replacive medium crystalline dolomite matrix (RD2) with higher intercrystalline porosity (black areas) compared to the pervasive replacive micro to fine-crystalline dolomite matrix (RD1). Sample 1-3-2; well: DGR1-CR2 (2); depth: 26.95 m; (E) photomicrograph (PPL) of planar-e to planar-s, selective replacive medium crystalline dolomite matrix (RD3) associated with dissolution seams showing dark cores and clear rims. Sample 8-4; well: DGR8-CR22; depth: $59.06 \mathrm{~m}$. (F) CL photomicrograph of selective replacive medium crystalline dolomite matrix (RD3) showing dull to red luminescence. Sample 1-3-2; well: DGR1-CR2 (2); depth: $313.31 \mathrm{~m}$. 
Table 2. Summary of the main petrographic characteristics of the carbonate minerals observed in Silurian and Devonian samples.

\begin{tabular}{|c|c|c|c|c|c|c|}
\hline Age & Mineral & Description & Texture & Size & Luminescence & $\begin{array}{c}\text { Ferroan/ } \\
\text { Non-Ferroan }\end{array}$ \\
\hline Silurian & RD1 & $\begin{array}{l}\text { Pervasive replacive micro to } \\
\text { fine crystalline dolomite matrix }\end{array}$ & $\begin{array}{l}\text { Non-planar to } \\
\text { planar-s }\end{array}$ & $<50 \mu \mathrm{m}$ & $\begin{array}{l}\text { Dully } \\
\text { red/bright }\end{array}$ & Non-ferroan \\
\hline Silurian & RD2 & $\begin{array}{l}\text { Pervasive replacive medium } \\
\text { crystalline dolomite matrix }\end{array}$ & Planar-e/planar-s & $\begin{array}{l}>50 \mu \mathrm{mup} \\
\text { to } 150 \mu \mathrm{m}\end{array}$ & $\begin{array}{l}\text { Dully red/ } \\
\text { non-luminescent }\end{array}$ & Non-ferroan \\
\hline Silurian & RD3 & $\begin{array}{l}\text { Selective replacive medium } \\
\text { crystalline dolomite matrix } \\
\text { (commonly associated with } \\
\text { dissolution seams) }\end{array}$ & Planar-e & $\begin{array}{l}>50 \mu \mathrm{m} \text { up } \\
\text { to } 150 \mu \mathrm{m}\end{array}$ & Dull/red & Non-ferroan \\
\hline Silurian & SD & $\begin{array}{l}\text { Coarse crystalline saddle } \\
\text { dolomite cement filling } \\
\text { fractures and vugs }\end{array}$ & $\begin{array}{l}\text { Curved crystal faces } \\
\text { and cleavage planes } \\
\text { and undulose } \\
\text { extinction }\end{array}$ & $>500 \mu \mathrm{m}$ & $\begin{array}{l}\text { Dull/ } \\
\text { non-luminescent }\end{array}$ & Ferroan \\
\hline Silurian & ISC & $\begin{array}{l}\text { Isopachous calcite cement } \\
\text { characterized by cement rims } \\
\text { growing around coated grains }\end{array}$ & bladed & $50-100 \mu \mathrm{m}$ & Dully red & Non-ferroan \\
\hline Silurian & SXC & $\begin{array}{l}\text { Syntaxial calcite overgrowth } \\
\text { cement usually around } \\
\text { echinoderm fragments }\end{array}$ & - & $\begin{array}{l}100 \mu \mathrm{m} \text { to } \\
>500 \mu \mathrm{m}\end{array}$ & Bright red & Ferroan \\
\hline Silurian & DC & $\begin{array}{l}\text { Void-filling and pore-lining } \\
\text { cement in intergranular and } \\
\text { intraskeletal pores, molds and } \\
\text { fractures }\end{array}$ & $\begin{array}{l}\text { Equant to elongate, } \\
\text { anhedral to subhedral }\end{array}$ & $\begin{array}{l}75-250 \mu \mathrm{m} \\
\text { Size increase } \\
\text { towards the } \\
\text { center }\end{array}$ & Dull red & Ferroan \\
\hline Silurian & BKC & $\begin{array}{l}\text { Blocky calcite cement } \\
\text { consisting of coarse-grained } \\
\text { crystals without a preferred } \\
\text { orientation mainly filling } \\
\text { fractures and voids }\end{array}$ & - & $\begin{array}{l}200 \mu \mathrm{m} \text { to } \\
>500 \mu \mathrm{m}\end{array}$ & $\begin{array}{l}\text { Red/bright } \\
\text { orange zoned }\end{array}$ & $\begin{array}{l}\text { Non-ferroan/ } \\
\text { ferroan }\end{array}$ \\
\hline Devonian & RD1 & $\begin{array}{l}\text { Pervasive replacive micro to } \\
\text { fine crystalline dolomite matrix }\end{array}$ & $\begin{array}{l}\text { Non-planar to } \\
\text { planar-s }\end{array}$ & $<50 \mu \mathrm{m}$ & Dull/red & Non-ferroan \\
\hline Devonian & RD2 & $\begin{array}{l}\text { Pervasive replacive medium } \\
\text { crystalline dolomite matrix }\end{array}$ & Planar-e/ planar-s & $\begin{array}{l}>50 \mu \mathrm{mup} \\
\text { to } 100 \mu \mathrm{m}\end{array}$ & $\begin{array}{l}\text { Dull/ } \\
\text { non-luminescent }\end{array}$ & Non-ferroan \\
\hline Devonian & RD3 & $\begin{array}{l}\text { Selective replacive medium } \\
\text { crystalline dolomite matrix } \\
\text { (commonly associated with } \\
\text { dissolution seams) }\end{array}$ & Planar-e & $\begin{array}{l}>50 \mu \mathrm{m} \text { up } \\
\text { to } 100 \mu \mathrm{m}\end{array}$ & Red/bright & Non-ferroan \\
\hline Devonian & SXC & $\begin{array}{l}\text { Syntaxial calcite overgrowth } \\
\text { cement usually around } \\
\text { echinoderm fragments }\end{array}$ & - & $\begin{array}{l}100 \mu \mathrm{m} \text { to } \\
>500 \mu \mathrm{m}\end{array}$ & Non-luminescent & Non-ferroan \\
\hline Devonian & DTC & $\begin{array}{l}\text { Dogtooth calcite cement } \\
\text { characterized by sharply } \\
\text { pointed acute crystals growing } \\
\text { normal to the substrate (mainly } \\
\text { skeletal grains) }\end{array}$ & $\begin{array}{l}\text { Elongate } \\
\text { scalenohedral or } \\
\text { rhombohedral }\end{array}$ & $50 \mu \mathrm{m}$ & $\begin{array}{l}\text { Red/bright } \\
\text { mostly zoned }\end{array}$ & Non-ferroan \\
\hline Devonian & DC & $\begin{array}{l}\text { Void-filling and pore-lining } \\
\text { cement in intergranular and } \\
\text { intraskeletal pores, molds and } \\
\text { fractures }\end{array}$ & $\begin{array}{l}\text { Equant to elongate, } \\
\text { anhedral to subhedral }\end{array}$ & $\begin{array}{l}75-250 \mu \mathrm{m} \\
\text { Size increase } \\
\text { towards the } \\
\text { center }\end{array}$ & $\begin{array}{l}\text { Dull red to } \\
\text { bright, } \\
\text { zoned in most } \\
\text { cases }\end{array}$ & Non-ferroan \\
\hline Devonian & $\mathrm{BKC}$ & $\begin{array}{l}\text { Blocky calcite cement } \\
\text { consisting of coarse-grained } \\
\text { crystals without a preferred } \\
\text { orientation mainly filling } \\
\text { fractures and voids }\end{array}$ & - & $\begin{array}{l}200 \mu \mathrm{m} \text { to } \\
>500 \mu \mathrm{m}\end{array}$ & $\begin{array}{l}\text { Red/bright } \\
\text { zoned }\end{array}$ & Non-ferroan \\
\hline
\end{tabular}

\subsubsection{Fracturing}

The fractures observed in the Devonian formations can be divided in two types. The first is represented by sub-horizontal fractures $(0.5-1 \mathrm{~cm})$ filled by blocky calcite cement (Figure 8A). 
The second type is represented by sub-vertical fractures $(0.1-0.5 \mathrm{~cm})$ commonly filled by blocky calcite (Figure 8A,B) crosscutting chemical compactional features (Figure 8C,D).
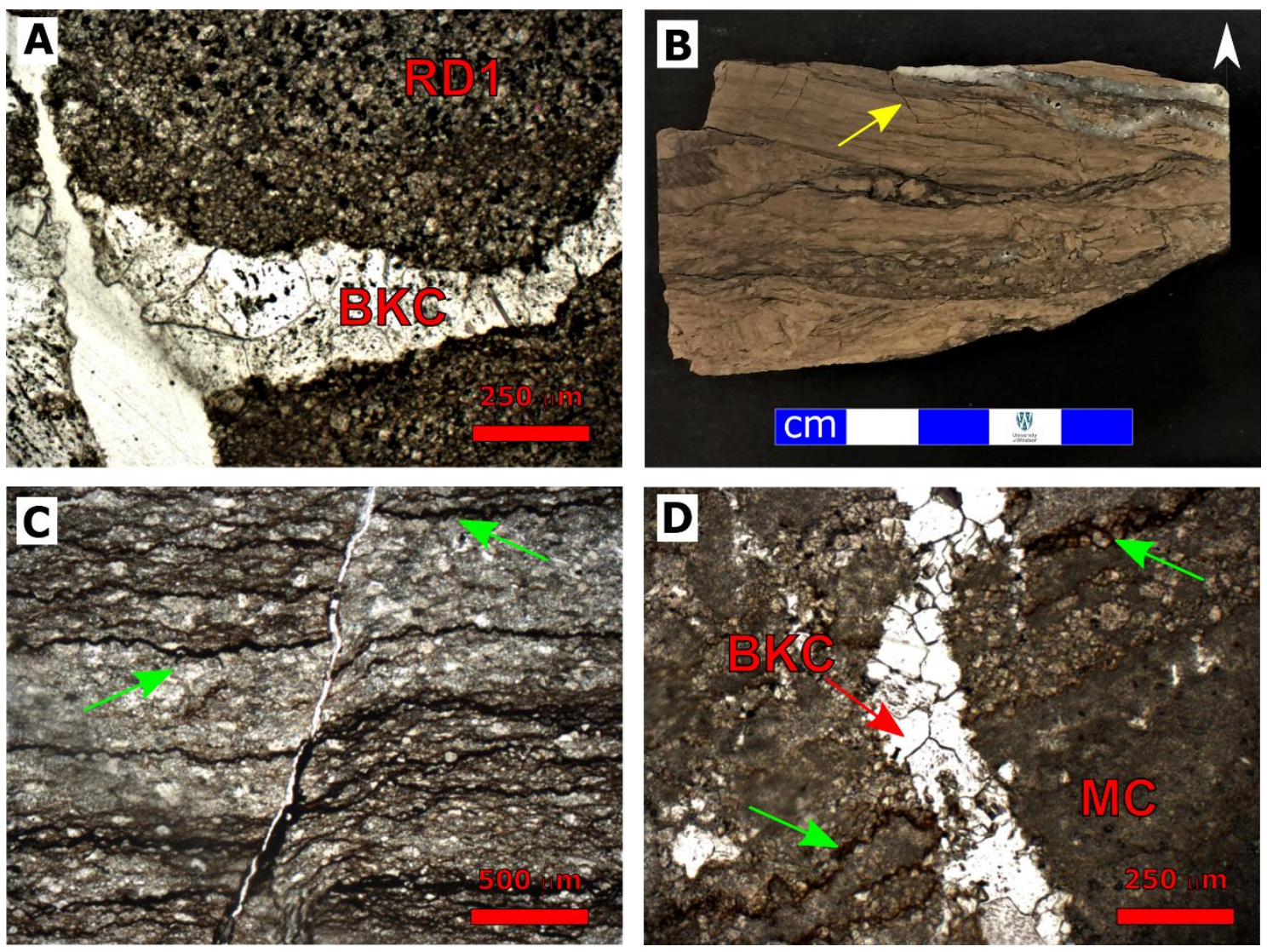

Figure 8. Fracturing in Devonian formation. (A) Photomicrograph (PPL) of a sub-vertical, unfilled hairline fracture cross-cutting sub-horizontal blocky calcite (BKC) vein in a fine crystalline dolostone. Sample 8-1; well: DGR8-CR10; depth: $22.71 \mathrm{~m}$; (B) Core photograph showing two systems of fractures in a dolostone from the Lucas Formation (Devonian). A sub-vertical unfilled hairline fracture (yellow arrow) crosscut a sub-horizontal fracture-filled by late calcite cement. The white arrow indicates the top of the sedimentary sequence. Sample 8-1; well: DGR8-CR10; depth: $22.71 \mathrm{~m}$. (C) Photomicrograph (PPL) of a sub-vertical, unfilled hairline fracture crosscutting and displacing dissolution seams (green arrows) and sedimentary structures in a partially dolomitized grainstone. Sample 1-9; well: DGR1-CR9; depth: $46.4 \mathrm{~m}$; (D) photomicrograph (PPL) of sub-vertical, blocky calcite (BKC) vein cross-cutting dissolution seams and stylolites (green arrows) in a partially dolomitized limestone. Note the presence of undolomitized micritic matrix (MC) from the precursor limestone. Sample 1-2; well: DGR1-CR2 (1); depth: $26.25 \mathrm{~m}$.

\subsubsection{Calcite Cementation}

Four types of calcite cement, ranging from early to late-stage, (Figure 9) have been distinguished, including syntaxial overgrowth, dogtooth, drusy and blocky calcite. Undolomitized calcite matrix (MC) from the precursor limestone was also observed in some specimens (Figure 8D). 

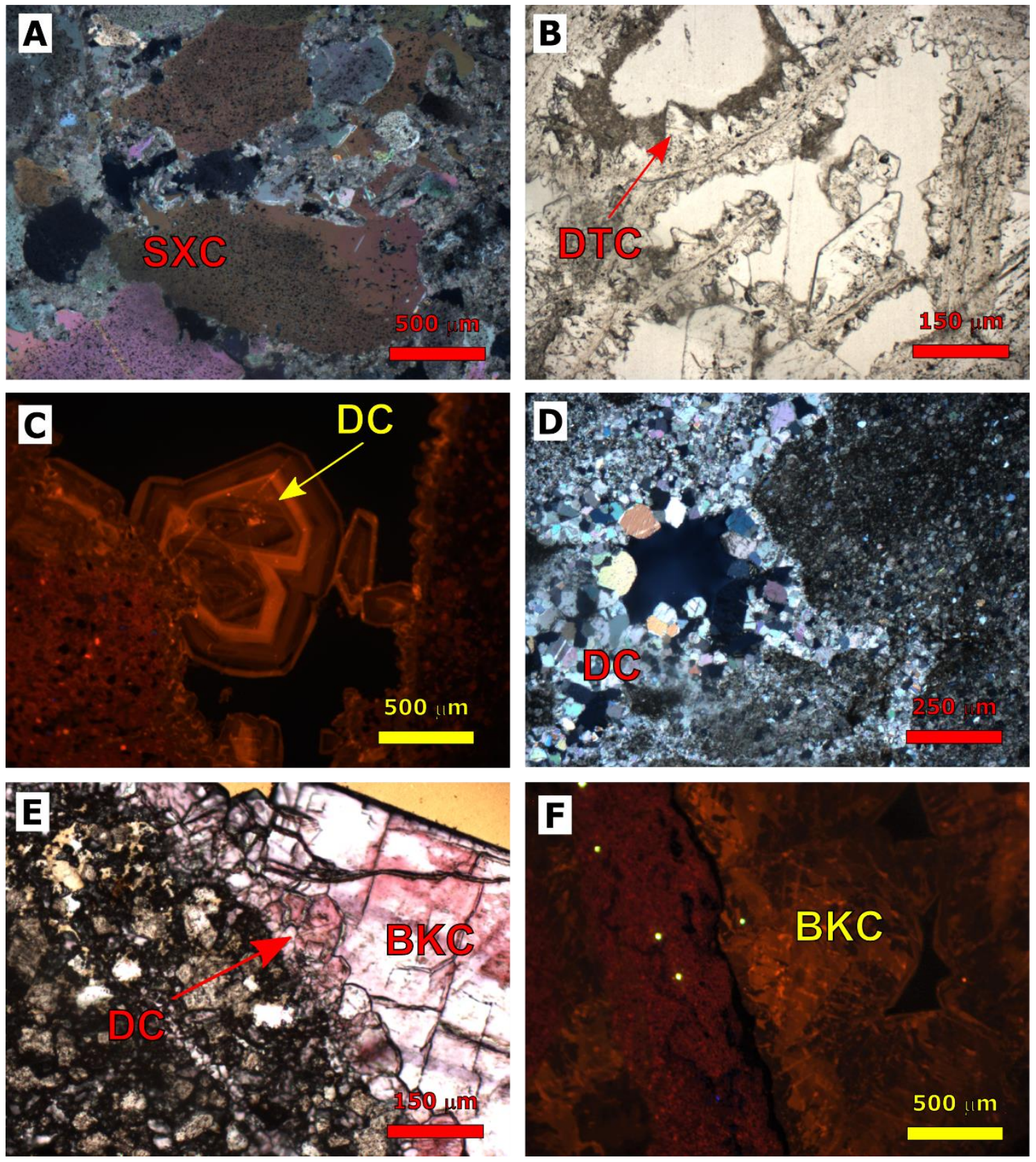

Figure 9. Calcite cementation in Devonian formations. (A) Photomicrograph (XPL) of syntaxial overgrowth calcite cement (SXC) on echinoderm skeletal fragments in a bioclastic grainstone. Sample 1-10; well: DGR1-CR10 (1); depth: 48.65 m; (B) photomicrograph (PPL) of dogtooth calcite cement (DTC) growing normally with respect to the surface of the intraskeletal chambers in a coral from a bioclastic grainstone. Sample 1-11; well: DGR1-CR10 (2); depth: 49.7 m; (C) CL photomicrograph of fracture-filling drusy calcite cement (DC) showing dull to bright zoned luminescence. Sample 1-13; well: DGR1-CR30 (1); depth: 26.95 m; (D) photomicrograph (XPL) of drusy calcite cement (DC) showing increasing crystal sizes towards the center of a fracture in a brecciated cherty dolostone. Sample 1-13; well: DGR1-CR30 (1); depth: 104.05 m; (E) photomicrograph (PPL-after staining) of non-ferroan, drusy calcite cement (DC) lining a fracture subsequently filled by non-ferroan blocky calcite (BKC) in fine crystalline dolostone. Sample 1-13; well: DGR1-CR30 (1); depth: 104.05 m; (F) CL photomicrograph of bright luminescent fracture-filling blocky calcite cement (BKC). Sample 8-1; well: DGR8-CR10; depth: $22.71 \mathrm{~m}$. 
Syntaxial calcite overgrowth cement (SXC) forms non-ferroan, non-luminescent crystals, usually around echinoderm fragments, ranging in size from $100 \mu \mathrm{m}$ up to $>500 \mu \mathrm{m}$ (Figure 9A).

Dogtooth calcite cement (DTC), is characterized by non-ferroan, non-luminescent, sharply pointed acute crystals $(50 \mu \mathrm{m})$ growing normal to the substrate. It is mainly observed lining intraskeletal chambers, and commonly presenting textures from elongate scalenohedral to rhombohedral (Figure 9B).

Pore-lining and void-filling drusy calcite cement (DC) is mainly observed in intergranular and intraskeletal pores, molds and fractures (Figure 9C-E). Common textural features show equant to elongate, in some cases anhedral to subhedral crystals ranging in size between 75-250 $\mu \mathrm{m}$ with dimension increasing towards the center of the pore space (Figure 9D). In most cases, DC is non-ferroan (Figure 9E) and shows zoned, dull-red to bright orange luminescence (Figure 9C).

A late fracture and void-filling blocky calcite cement (BKC) consisting of the coarse-grained, non-ferroan crystal (Figure 9E) without preferred orientation, ranges in size from $200 \mu \mathrm{m}$ to $>500 \mu \mathrm{m}$, shows zoned red to bright orange luminescence under CL (Figure 9F).

Paragenetically, early calcite cement (SXC, DTC and DC) predate replacive dolomite matrix RD1, $\mathrm{RD} 2$ and RD3, and predate the late fracture- and pore-filling blocky calcite (BKC) cement.

\subsection{Geochemistry of Silurian and Devonian Formations}

\subsubsection{Oxygen and Carbon Stable Isotopes}

The isotopic composition of RD1 from the two age groups shows more negative $\delta^{18} \mathrm{O}$ and $\delta^{13} \mathrm{C}$ average values in the Silurian samples than in the Devonian samples. $\delta^{18} \mathrm{O}$ isotopic composition of Silurian and Devonian pervasive replacive micro to fine crystalline dolomite matrix (RD1) range from -7.83 to $-4.46 \%$ o VPDB (average: $-6.43 \%$ o $\pm 1.1 \%$ ) and from -7.01 to $-4.46 \%$ o VPDB (average: $-5.95 \%$ o $\pm 0.71 \%$ o), respectively. $\delta^{13} \mathrm{C}$ isotopic values in $\mathrm{RD} 1$ samples range from -2.73 to $3.78 \%$ o VPDB (average: $0.18 \%$ o $\pm 1.9 \%$ o) for Silurian formations and from 2.01 to $4.28 \%$ o VPDB (average: $3.05 \%$ o \pm $0.88 \%$ ) for Devonian formations ( $\mathrm{n}=20$; Figure 10; Table 3).

The isotopic compositions of RD2 from Silurian formations show more negative $\delta^{18} \mathrm{O}$ and $\delta^{13} \mathrm{C}$ average values than values of RD2 from Devonian samples. $\delta^{18} \mathrm{O}$ isotopic composition of Silurian and Devonian pervasive replacive medium crystalline dolomite matrix (RD2) range from -7.96 to $-3.85 \%$ o VPDB (average: $-6.62 \%$ o $\pm 1.37 \%$ ) and from -7.66 to $-4.75 \%$ VPDB (average: $-6.11 \%$ o $\pm 1.07 \%$ ), respectively. $\delta^{13} \mathrm{C}$ isotopic concentrations in RD2 samples range from -0.32 to $3.84 \%$ o VPDB (average: $2.15 \%$ o $\pm 1.37 \%$ o) for Silurian formations and from 0.99 to $3.93 \%$ o VPD (average: $2.75 \%$ o $\pm 1.21 \%$ o) for Devonian successions ( $\mathrm{n}=12$; Figure 10; Table 3).

RD3 from Silurian samples is characterized by more negative $\delta^{18} \mathrm{O}$ average values but comparable $\delta^{13} \mathrm{C}$ average values Devonian samples. $\delta^{18} \mathrm{O}$ isotopic composition of Silurian and Devonian selective replacive medium crystalline dolomite matrix (RD3) range from -7.53 to $-5.91 \%$ VPDB (average: $-6.95 \%$ o $\pm 0.9 \%$ o) and from -6.20 to $-3.91 \%$ o VPDB (average: $-5.31 \%$ o $\pm 0.71 \%$ o), respectively. $\delta^{13} \mathrm{C}$ isotopic concentrations in RD3 samples range from 0.65 to $4.02 \%$ VPDB (average: $2.66 \%$ o $\pm 1.77 \%$ o) for Silurian formations and from 1.09 to $4.63 \%$ VPDB (average: $3.08 \%$ o $\pm 1.07 \%$ ) for Devonian successions ( $\mathrm{n}=11$; Figure 10; Table 3). 


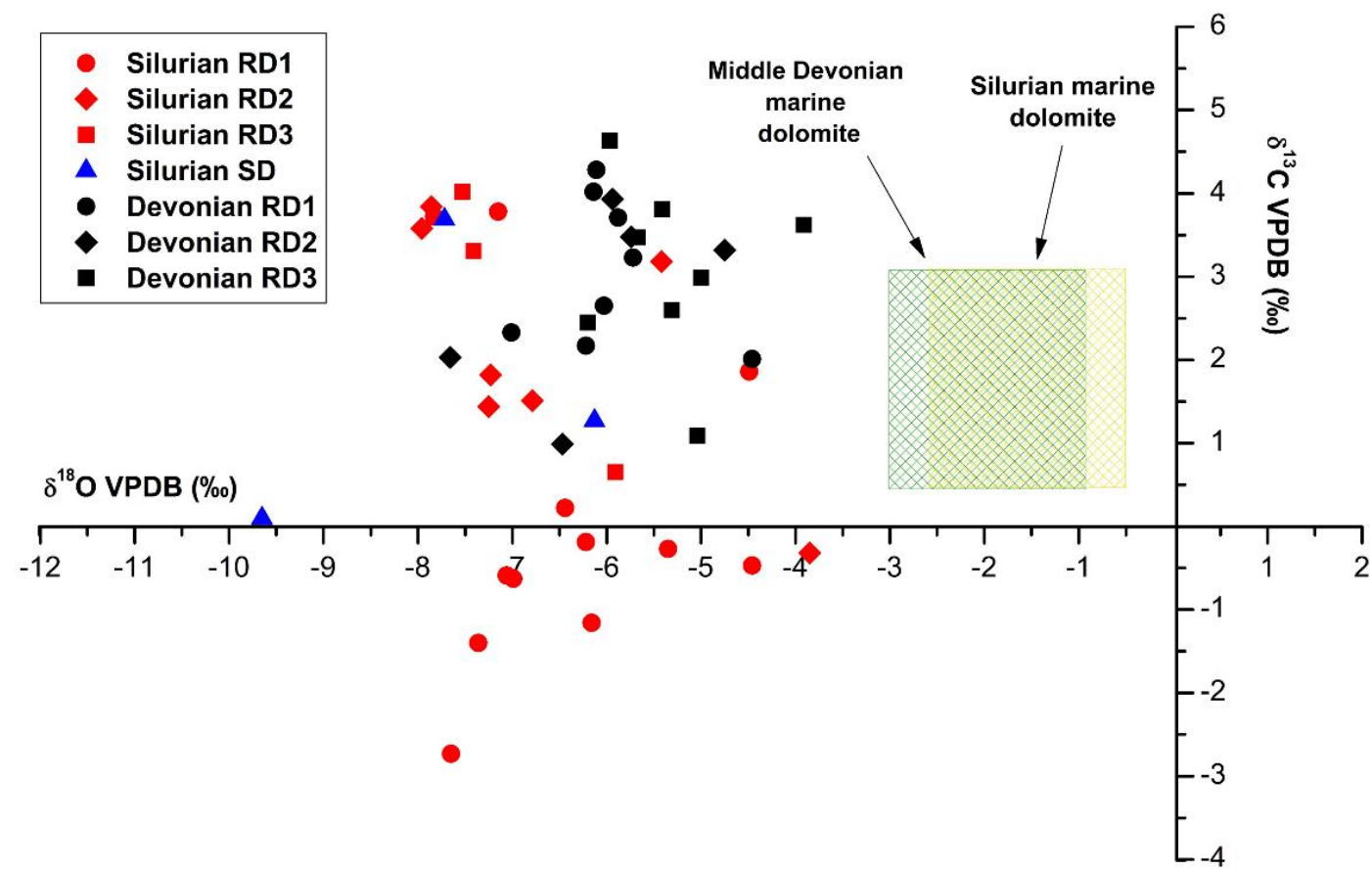

Figure 10. Cross plot of $\delta^{13} \mathrm{C}$ vs $\delta^{18} \mathrm{O}$ of different types of dolomite in Silurian and Devonian formations. The data shows an overlap between $\delta^{13} \mathrm{C}$ and $\delta^{18} \mathrm{O}$ values in Silurian and Devonian dolomites. In both age groups, $\delta^{13} \mathrm{C}$ values fall in the range of values estimated for the marine calcite of equivalent age except for the more negative values in some Silurian RD1 samples possibly related to bacterial sulfate reduction (BSR). The negative shift in $\delta^{18} \mathrm{O}$ values, more pronounced in Silurian dolomites, can be related to dolomite recrystallization during burial and increasing temperature. The green box represents isotopic values of the Middle Devonian marine calcite [49] and the yellow box represents the estimated isotopic values for the Silurian marine dolomite [50].

Table 3. Oxygen and carbon stable isotopes, $\mathrm{Sr}$ isotopes results from dolomite and calcite samples.

\begin{tabular}{|c|c|c|c|c|c|}
\hline Sample ID & Age & Phase & $\delta^{13} C_{\text {VPDB }}(\%$ o) & $\delta^{18} \mathrm{O}_{\text {VPDB }}(\%$ o $)$ & ${ }^{87} \mathrm{Sr} /{ }^{86} \mathrm{Sr}$ \\
\hline $1-15 a$ & Silurian & RD1 & -0.47 & -4.46 & \\
\hline $1-16 a$ & Silurian & RD1 & -0.27 & -5.35 & \\
\hline $1-17 a$ & Silurian & RD1 & 1.86 & -4.49 & 0.708705 \\
\hline $1-18 a$ & Silurian & RD1 & -2.73 & -7.65 & 0.708877 \\
\hline $1-20 a$ & Silurian & RD1 & -0.59 & -7.06 & \\
\hline $1-21 a$ & Silurian & RD1 & 0.22 & -6.44 & \\
\hline $1-31 a$ & Silurian & RD1 & 3.78 & -7.15 & \\
\hline $8-6 a$ & Silurian & RD1 & -1.4 & -7.36 & 0.708919 \\
\hline $8-5 a$ & Silurian & RD1 & -0.63 & -6.99 & \\
\hline $8-8 \mathrm{a}$ & Silurian & RD1 & -1.16 & -6.16 & \\
\hline $8-9 a$ & Silurian & RD1 & -0.19 & -6.22 & \\
\hline $8-13 a$ & Silurian & RD1 & 3.72 & -7.83 & \\
\hline $1-16 b$ & Silurian & RD2 & -0.32 & -3.85 & \\
\hline $1-24 a$ & Silurian & RD2 & 1.51 & -6.79 & 0.708469 \\
\hline $1-23 b$ & Silurian & RD2 & 1.44 & -7.25 & \\
\hline $1-31 b$ & Silurian & RD2 & 3.58 & -7.96 & 0.708587 \\
\hline $8-11 a$ & Silurian & RD2 & 3.18 & -5.42 & \\
\hline $8-10 b$ & Silurian & RD2 & 1.82 & -7.23 & \\
\hline $8-13 b$ & Silurian & RD2 & 3.84 & -7.86 & \\
\hline $1-30 a$ & Silurian & RD3 & 4.02 & -7.53 & 0.708905 \\
\hline $1-33 b$ & Silurian & RD3 & 0.65 & -5.91 & \\
\hline $8-12$ & Silurian & RD3 & 3.31 & -7.41 & 0.708743 \\
\hline
\end{tabular}


Table 3. Cont.

\begin{tabular}{|c|c|c|c|c|c|}
\hline Sample ID & Age & Phase & $\delta^{13} C_{\text {VPDB }}(\% o)$ & $\delta^{18} \mathrm{O}_{\text {VPDB }}(\%$ oo $)$ & ${ }^{87} \mathrm{Sr} /{ }^{86} \mathrm{Sr}$ \\
\hline $1-31 c$ & Silurian & SD & 3.69 & -7.72 & 0.708648 \\
\hline $8-13 c$ & Silurian & SD & 0.10 & -9.65 & \\
\hline $1-28 a$ & Silurian & SD & 1.27 & -6.13 & 0.708516 \\
\hline $1-24 b$ & Silurian & $\mathrm{MC}$ & 1.32 & -5.55 & \\
\hline $1-27 b$ & Silurian & $\mathrm{MC}$ & 0.14 & -8.16 & \\
\hline $1-30 b$ & Silurian & $\mathrm{MC}$ & 3.53 & -8.09 & \\
\hline $1-33 c$ & Silurian & $\mathrm{MC}$ & 0.21 & -4.73 & \\
\hline $8-11 b$ & Silurian & $\mathrm{MC}$ & 2.89 & -5.35 & \\
\hline $1-23 a$ & Silurian & ISC & 1.37 & -6.76 & \\
\hline $8-10 a$ & Silurian & ISC & 1.27 & -7.77 & \\
\hline $1-32$ & Silurian & SXC & 0.12 & -4.81 & \\
\hline $1-33 a$ & Silurian & SXC & -0.21 & -5.54 & \\
\hline $1-17 \mathrm{~b}$ & Silurian & $\mathrm{DC}$ & -0.88 & -8.85 & 0.708154 \\
\hline $1-25$ & Silurian & $\mathrm{BKC}$ & 0.02 & -4.54 & \\
\hline $1-26 a$ & Silurian & $\mathrm{BKC}$ & 0.00 & -6.78 & \\
\hline $1-27 a$ & Silurian & $\mathrm{BKC}$ & 0.03 & -7.52 & 0.708383 \\
\hline $1-28 b$ & Silurian & $\mathrm{BKC}$ & 0.06 & -7.51 & \\
\hline $1-31 d$ & Silurian & $\mathrm{BKC}$ & 3.17 & -6.41 & \\
\hline $8-5 b$ & Silurian & $\mathrm{BKC}$ & -3.75 & -9.19 & 0.708054 \\
\hline $8-9 c$ & Silurian & $\mathrm{BKC}$ & -1.06 & -10.19 & \\
\hline $8-13 d$ & Silurian & $\mathrm{BKC}$ & 3.10 & -8.09 & \\
\hline $8-9 d$ & Silurian & GY & - & - & 0.708486 \\
\hline $1-29 a$ & Silurian & GY & - & - & 0.708434 \\
\hline $1-1 \mathrm{a}$ & Devonian & RD1 & 2.65 & -6.03 & 0.708103 \\
\hline $1-1 b$ & Devonian & RD1 & 2.17 & -6.22 & \\
\hline $1-3-1 a$ & Devonian & RD1 & 3.23 & -5.72 & \\
\hline $1-5 a$ & Devonian & RD1 & 4.02 & -6.14 & \\
\hline $1-5 b$ & Devonian & RD1 & 4.28 & -6.11 & \\
\hline $1-7 \mathrm{a}$ & Devonian & RD1 & 3.71 & -5.88 & \\
\hline $8-1 a$ & Devonian & RD1 & 2.01 & -4.46 & 0.707884 \\
\hline $8-4 a$ & Devonian & RD1 & 2.33 & -7.01 & \\
\hline $1-3-2 b$ & Devonian & RD2 & 3.32 & -4.75 & 0.708089 \\
\hline $1-4 a$ & Devonian & RD2 & 3.93 & -5.94 & \\
\hline $1-7 b$ & Devonian & RD2 & 3.48 & -5.74 & \\
\hline $1-14 a$ & Devonian & RD2 & 0.99 & -6.47 & \\
\hline $8-4 b$ & Devonian & RD2 & 2.03 & -7.66 & 0.708920 \\
\hline $1-2 a$ & Devonian & RD3 & 3.47 & -5.67 & \\
\hline $1-3-2 c$ & Devonian & RD3 & 3.62 & -3.91 & \\
\hline $1-6 a$ & Devonian & RD3 & 4.63 & -5.97 & 0.708146 \\
\hline $1-10 a$ & Devonian & RD3 & 2.60 & -5.31 & \\
\hline $1-13 b$ & Devonian & RD3 & 1.09 & -5.04 & \\
\hline $8-2 a$ & Devonian & RD3 & 3.81 & -5.41 & \\
\hline $8-3 a$ & Devonian & RD3 & 2.99 & -5.00 & \\
\hline $8-4 c$ & Devonian & RD3 & 2.45 & -6.20 & 0.708509 \\
\hline $1-2 b$ & Devonian & $\mathrm{MC}$ & 2.52 & -5.87 & \\
\hline $1-4 b$ & Devonian & $\mathrm{MC}$ & 2.81 & -5.77 & \\
\hline $1-6 b$ & Devonian & $\mathrm{MC}$ & 4.12 & -4.53 & \\
\hline $1-8 b$ & Devonian & $\mathrm{MC}$ & 1.92 & -6.47 & \\
\hline $8-2 b$ & Devonian & $\mathrm{MC}$ & 2.83 & -6.59 & \\
\hline $8-3 b$ & Devonian & $\mathrm{MC}$ & 1.99 & -6.51 & \\
\hline $1-11 a$ & Devonian & SXC & 0.97 & -4.44 & \\
\hline $1-12 a$ & Devonian & SXC & 1.55 & -4.42 & \\
\hline $1-13 a$ & Devonian & $\mathrm{DC}$ & -0.59 & -6.22 & 0.708051 \\
\hline $1-14 b$ & Devonian & $\mathrm{DC}$ & -1.15 & -6.49 & \\
\hline $1-2 c$ & Devonian & $\mathrm{BKC}$ & -1.55 & -8.01 & \\
\hline $8-1 b$ & Devonian & $\mathrm{BKC}$ & -2.40 & -8.61 & 0.707982 \\
\hline
\end{tabular}


The $\delta^{18} \mathrm{O}$ and $\delta^{13} \mathrm{C}$ isotopic values of Silurian Saddle dolomite cement (SD) range from -9.65 to $-6.13 \%$ o VPDB (average: $-7.84 \% \pm 1.76 \%$ o) and from 0.10 to $3.69 \%$ VPDB (average: $1.69 \% \pm 1.83 \%$ o), respectively $(\mathrm{n}=3$; Figure 10 and Table 3$)$.

Early calcite shows more negative $\delta^{18} \mathrm{O}$ and more positive $\delta^{13} \mathrm{C}$ average values in Devonian formations compared with Silurian samples. Silurian and Devonian early calcite matrix and cement (MC, ISC, SXC, DTC and DC) show $\delta^{18} \mathrm{O}$ isotopic composition ranging from -8.85 to $-4.73 \%$ VPDB (average: $-6.56 \%$ o $\pm 1.47 \%$ ) and from -6.59 to $-4.42 \%$ VPDB (average: $-5.73 \% \pm 0.87 \%$ ), respectively. $\delta^{13} \mathrm{C}$ isotopic values in early calcite samples (MC, ISC, SXC, DTC and DC) range from -0.88 to $3.53 \%$ VPDB (average: $0.97 \%$ \% $1.32 \%$ ) for Silurian formations and from -1.15 to $4.12 \%$ VPDB (average: $1.70 \% \pm 1.52 \%$ o for Devonian successions $(n=20$; Figure 11; Table 3$)$.

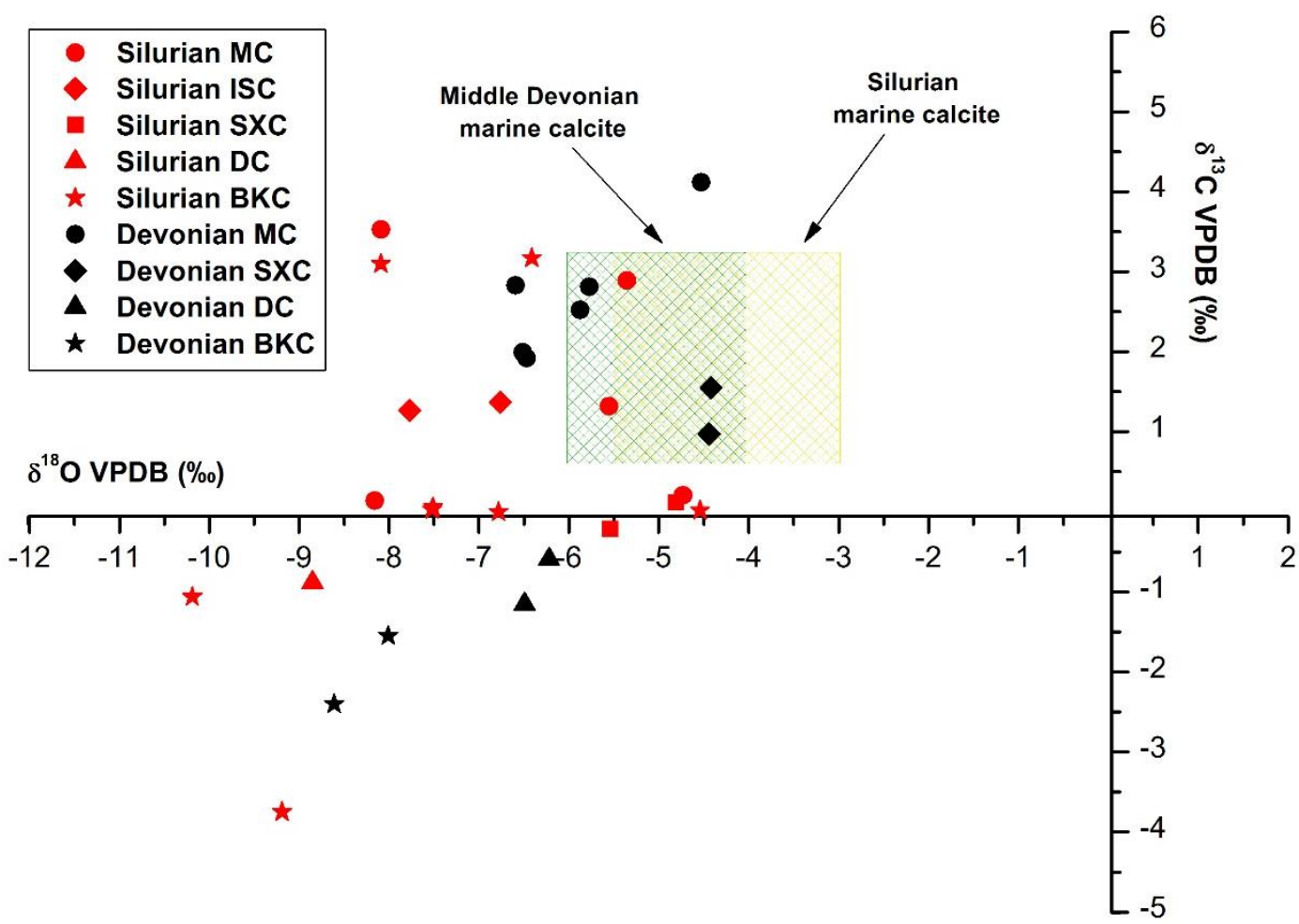

Figure 11. Crossplot of $\delta^{13} \mathrm{C}$ vs $\delta^{18} \mathrm{O}$ of different generations of calcite cement in Silurian and Devonian formations. Most of the calcitic samples show $\delta^{13} \mathrm{C}$ values, in range with postulated values for marine calcite of the respective age with the exception for late BKC which clearly shows a negative shift from the equilibrium values in both age groups. This may suggest a separate input of oxidized organic carbon possibly related to interaction with hydrocarbons. The green box represents isotopic values of the Middle Devonian marine calcite [49] and the yellow box represents the estimated isotopic values for the Silurian marine dolomite [50].

Late calcite cement (BKC) shows more negative $\delta^{18} \mathrm{O}$ and $\delta^{13} \mathrm{C}$ average values in Devonian formations compared with the Silurian samples. The $\delta^{18} \mathrm{O}$ isotopic composition of Silurian and Devonian late fracture-filling calcite cement (BKC) range from -10.19 to $-4.54 \%$ VPDB (average: $-7.53 \%$ \% $\pm 1.62 \%$ ) and from -8.61 to $-8.01 \%$ VPDB (average: $-8.31 \% \pm 0.3 \%$ ), respectively. $\delta^{13} \mathrm{C}$ isotopic concentrations in BKC samples range from -3.75 to $3.17 \%$ VPDB (average: $0.20 \% \pm 2.08 \%$ o) for Silurian formations and from -2.40 to $-1.55 \%$ VPDB (average: $-1.98 \% \pm 0.43 \%$ ) for Devonian successions ( $n=10$; Figure 11; Table 3). 


\subsubsection{Strontium Isotopes}

Due to the mixed nature of the samples, only one pure sample of drusy calcite cement (DC), for each age group, were microsampled avoiding then contamination with other carbonate minerals. The Sr isotopic values of DC were 0.708154 and 0.708051 for the Silurian and Devonian samples, respectively (Figure 12). The Silurian late calcite cement (BKC) show ${ }^{87} \mathrm{Sr} /{ }^{86} \mathrm{Sr}$ isotopic ratio values ranging from 0.708054 to $0.708383(\mathrm{n}=2)$ and 0.707982 for Devonian BKC $(\mathrm{n}=1) .{ }^{87} \mathrm{Sr} /{ }^{86} \mathrm{Sr}$ ratios of matrix dolomite samples (RD1, RD2 and RD3) from the Silurian $(n=7)$ and Devonian $(n=6)$ carbonate successions range from 0.708469 to 0.708919 and 0.707884 to 0.708920 , respectively. Saddle dolomite sampled from Silurian formations has $\mathrm{Sr}$ isotopic values ranging from 0.708516 to $0.708648(\mathrm{n}=2$; Figure 12). Gypsum samples from Silurian formations show Sr isotopic values ranging from 0.708434 to 0.708486 .

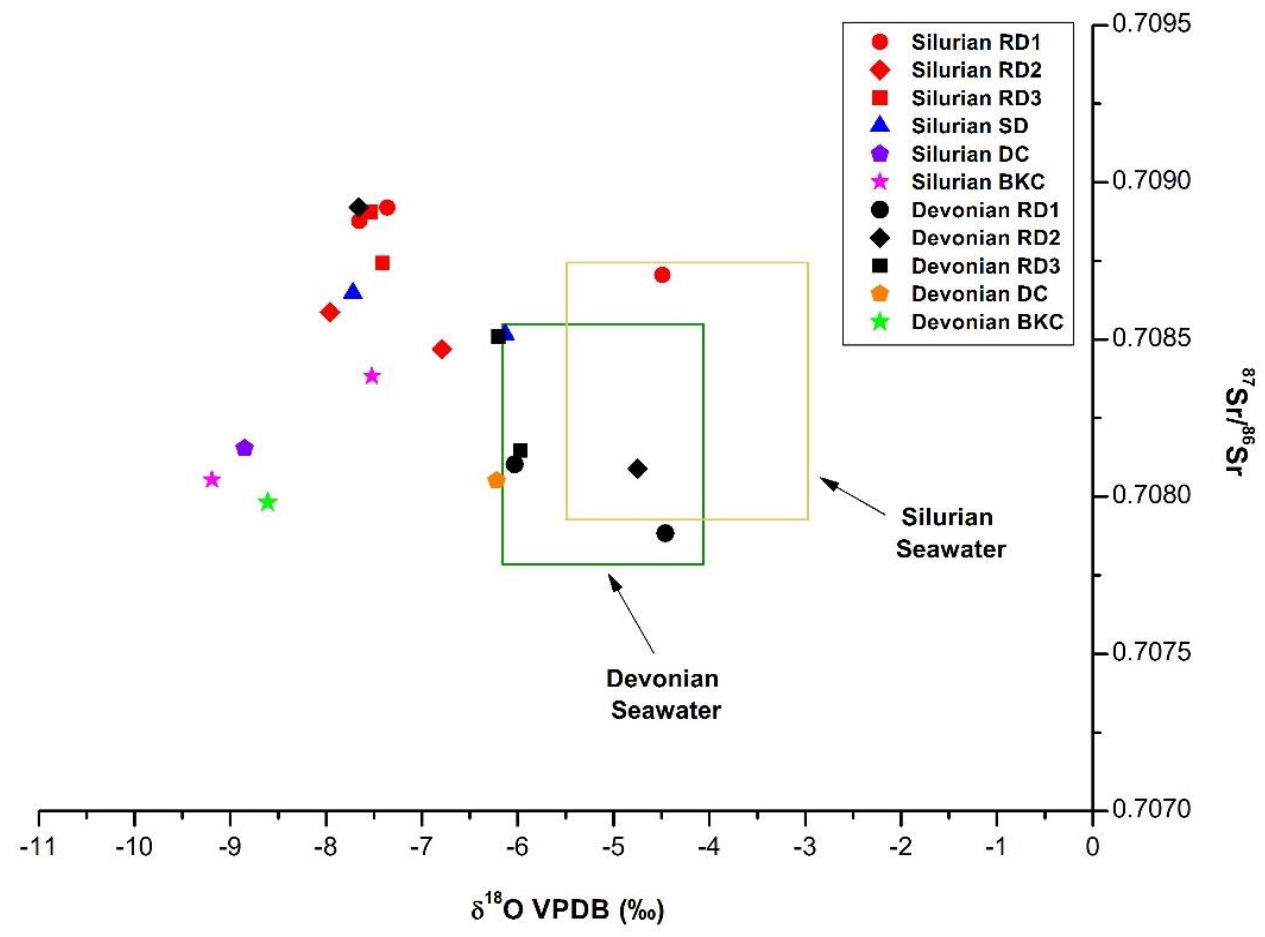

Figure 12. Cross plot of $\delta^{18} \mathrm{O}$ vs ${ }^{87} \mathrm{Sr} /{ }^{86} \mathrm{Sr}$ ratios of different dolomitic and calcitic components from the two age groups. In both age groups, Sr isotopic ratios show seawater composition of their respective age as the primary source of diagenetic fluids with minor rock-water interactions as indicated by some exceptions of more radiogenic signatures in the Silurian formations. The green box represents Devonian seawater [51] and the yellow box represents Silurian seawater [51,52].

${ }^{87} \mathrm{Sr} /{ }^{86} \mathrm{Sr}$ isotopic ratios for dolomite and calcite by age are presented in Table 3.

\subsubsection{Fluid Inclusions Microthermometry}

Fluid inclusions measurements were focused only on dolomite and blocky calcite cement. Due to the small size of crystal and/or fluid inclusions, microthermometric measurements in mineral phases such as RD1and RD3 were not achievable in both age groups. The melting (Tm) and homogenization temperatures $\left(T_{h}\right)$ were measured from two-phase, liquid-rich primary fluid inclusions which ranged in size from $1 \mu \mathrm{m}$ up to $20 \mu \mathrm{m}$ in diameter with variable shapes from irregular to nearly circular (Figure 13). In some cases, measurements of the melting temperatures for fluid inclusions hosted in RD2 were not possible due to their small size in both Silurian and Devonian successions (measured $\mathrm{n}=9$ and $\mathrm{n}=7$ for Silurian and Devonian samples, respectively). Hydrocarbon fluid inclusions were not identified in the selected samples from the studied formations. 

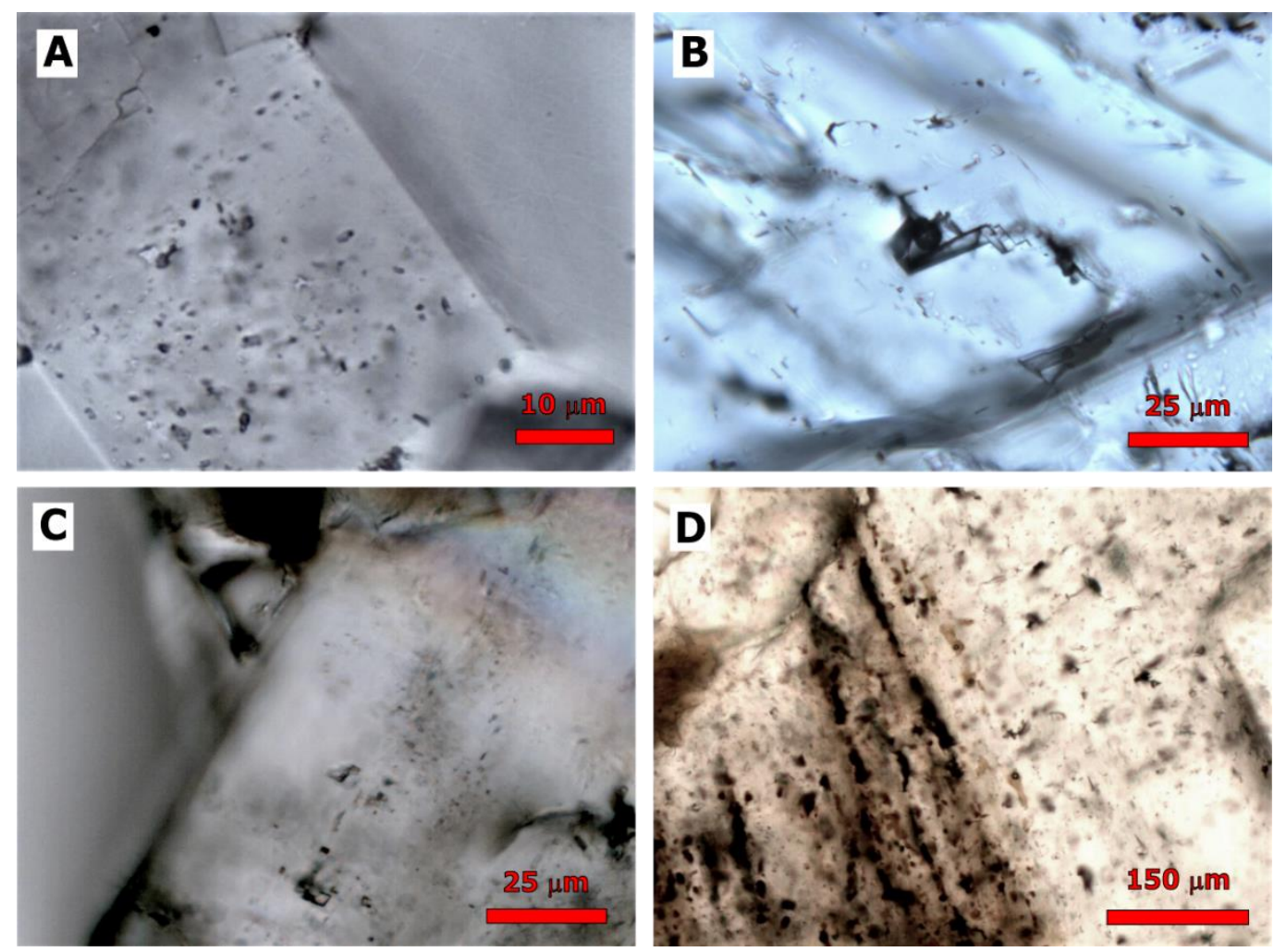

Figure 13. Fluid Inclusion assemblages. (A) Photomicrograph (PPL) of fluid inclusion assemblage in an RD2 crystal from Lucas Formation. Sample 1-3-2; Well: DGR1-CR2 (2); depth: 26.95 m; (B) photomicrograph (PPL) of isolated two-phase, primary fluid inclusions (liquid-rich with vapor bubble) hosted within blocky calcite cement occluding fractures in the Lucas Formation. Sample 8-1; Well: DGR8-CR10; depth: $22.71 \mathrm{~m}$; (C) photomicrograph (PPL) of fluid inclusions assemblage in RD2 along the crystal growth showing two-phase primary fluid inclusions. Sample 1-31; well: DGR1-CR133; depth: $378.1 \mathrm{~m}$; (D) photomicrograph (PPL) of fluid inclusion assemblage in SD along the crystal growth, showing a trail of two-phase primary fluid inclusions with irregular and elongated shapes. Sample 1-28; well: DGR1-CR121; depth: $342.27 \mathrm{~m}$.

Fluid inclusions hosted in RD2 from Silurian samples show higher $\mathrm{T}_{\mathrm{h}}$ and salinity compared to fluid inclusions hosted in RD2 from Silurian formations. Microthermometric results of pervasive, replacive medium crystalline dolomite matrix (RD2) vary from $\mathrm{T}_{\mathrm{h}}: 49.7$ to $134.1{ }^{\circ} \mathrm{C}$ (average: $89.1 \pm 20.9$ ), 22.03 to 25.2 wt. $\% \mathrm{NaCl}$ eq. (average: $23.3 \pm 1.1$ ) and $\mathrm{T}_{\mathrm{h}}: 69.9$ to $102.3{ }^{\circ} \mathrm{C}$ (average: $82.7 \pm 9.8$ ), 18.9 to 21.8 wt. $\% \mathrm{NaCl}$ eq. (average: $20.8 \pm 0.9$ ) for the Silurian and Devonian samples, respectively.

Saddle dolomite (SD) hosted in Silurian successions shows values ranging from $\mathrm{T}_{\mathrm{h}}: 101.2$ to $193.4{ }^{\circ} \mathrm{C}$ (average: $124.8 \pm 20.5$ ), 25.97 to $32.6 \mathrm{wt}$ \% $\mathrm{NaCl}$ eq. (average: $28.5 \pm 1.8$ ).

Fluid inclusions hosted in BKC from Silurian samples show lower $\mathrm{T}_{\mathrm{h}}$ and higher salinity compared to fluid inclusions hosted in BKC from Silurian formations. In late calcite cement (BKC), measured values range from $\mathrm{T}_{\mathrm{h}}: 70.2$ to $194.3^{\circ} \mathrm{C}$ (average: $120.9 \pm 35.4$ ), 21.4 to $32.3 \mathrm{wt} . \% \mathrm{NaCl}$ eq. (average: $27.6 \pm 3.2$ ) and $\mathrm{T}_{\mathrm{h}}: 146.20$ to $237.9{ }^{\circ} \mathrm{C}$ (average: $194.87 \pm 26.9$ ), 15.17 to $23.95 \mathrm{wt}$ \% $\mathrm{NaCl}$ eq. (average: $20.21 \pm 2.31$ ) for the mentioned age groups, respectively.

The summaries of the fluid inclusion results are presented in Figures 14-16 and Table 4. Examples of the main characteristics of fluid inclusion assemblages hosted within the different calcite and dolomite phases are illustrated in Figure 13. 

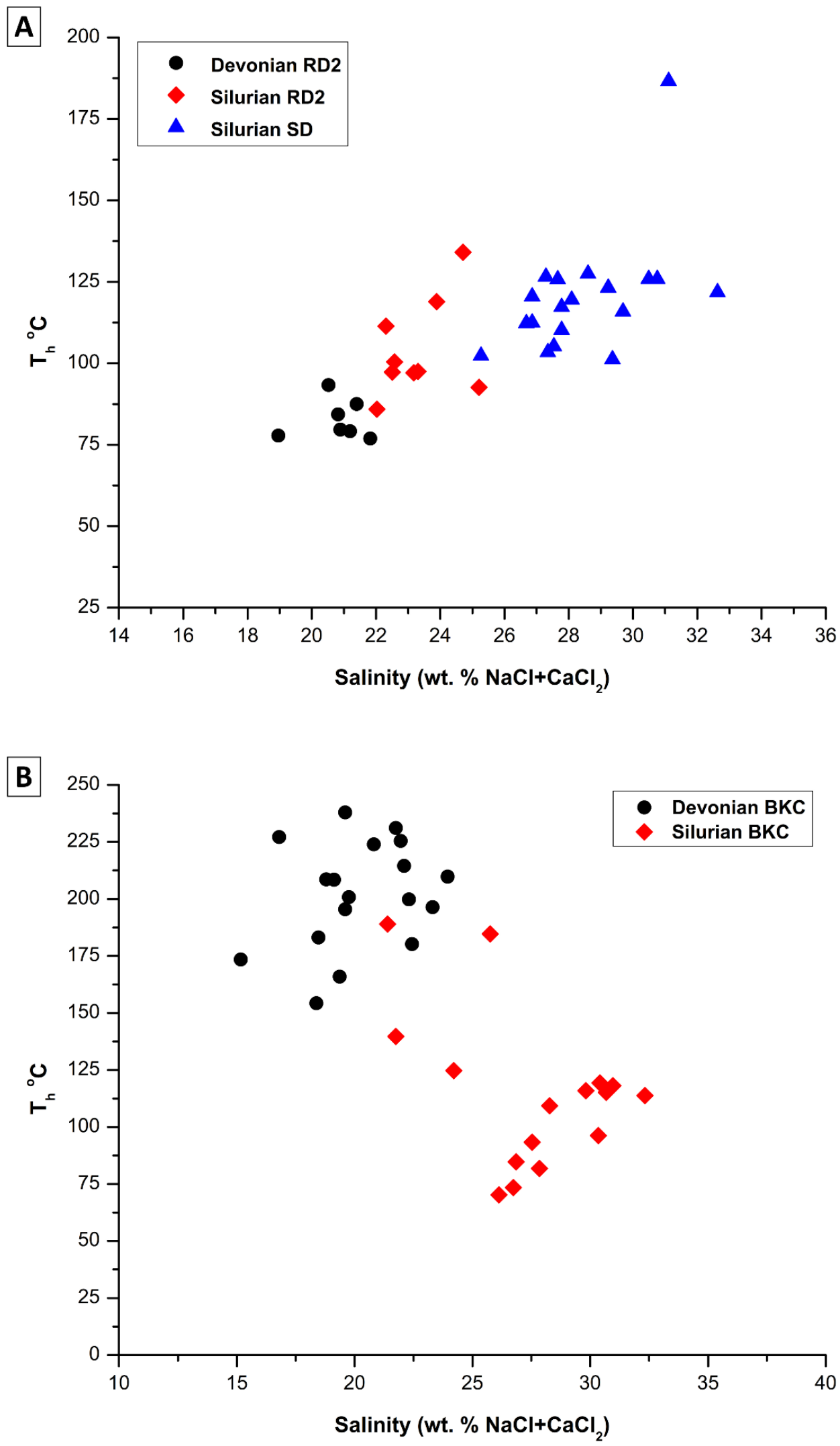

Figure 14. Homogenization temperature vs. salinity cross plots for analyzed (A) dolomite and (B) calcite phases. 

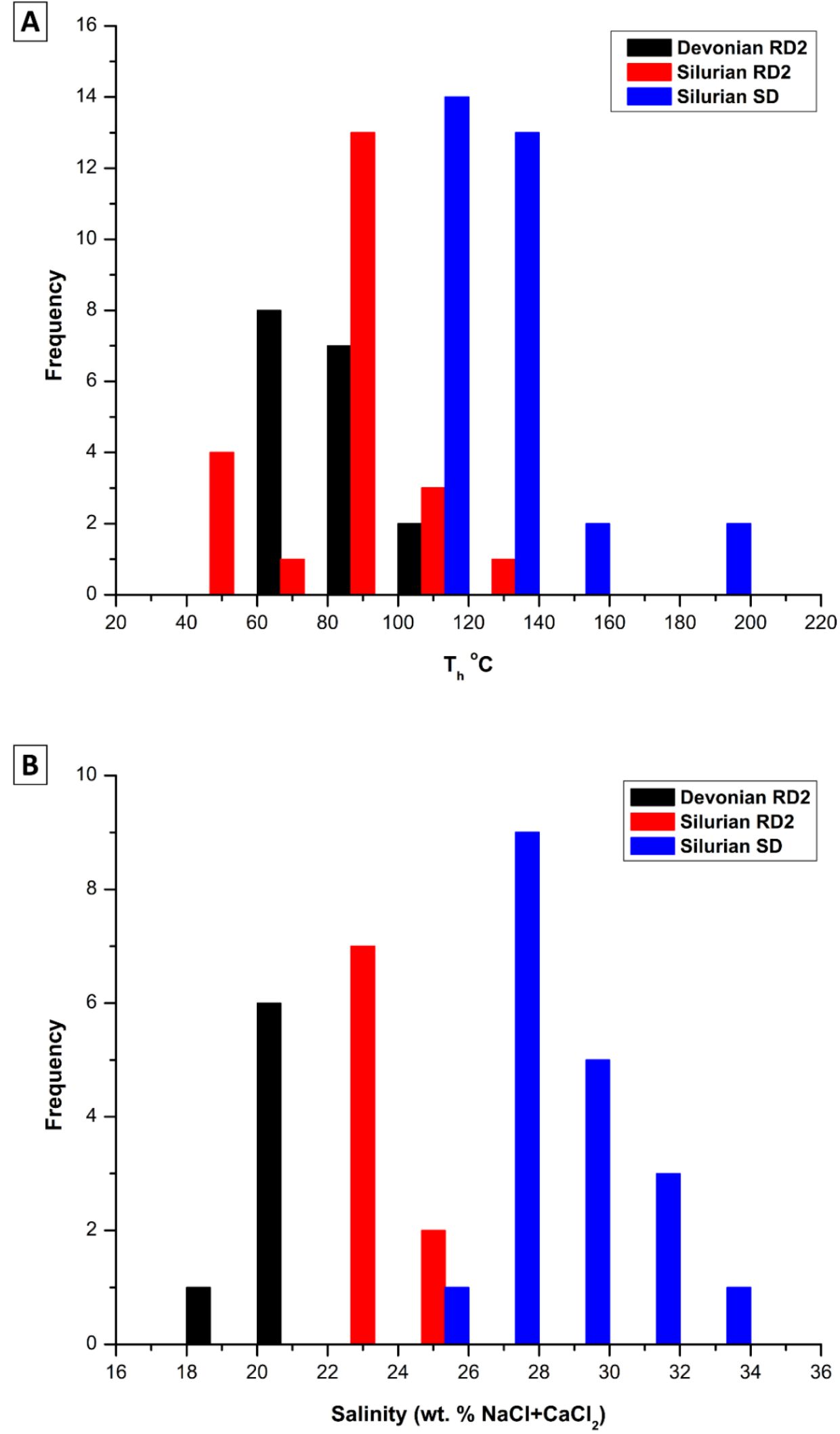

Figure 15. Histogram plots of (A) homogenization temperature and (B) salinity for analyzed dolomite phases in Silurian and Devonian formations. 

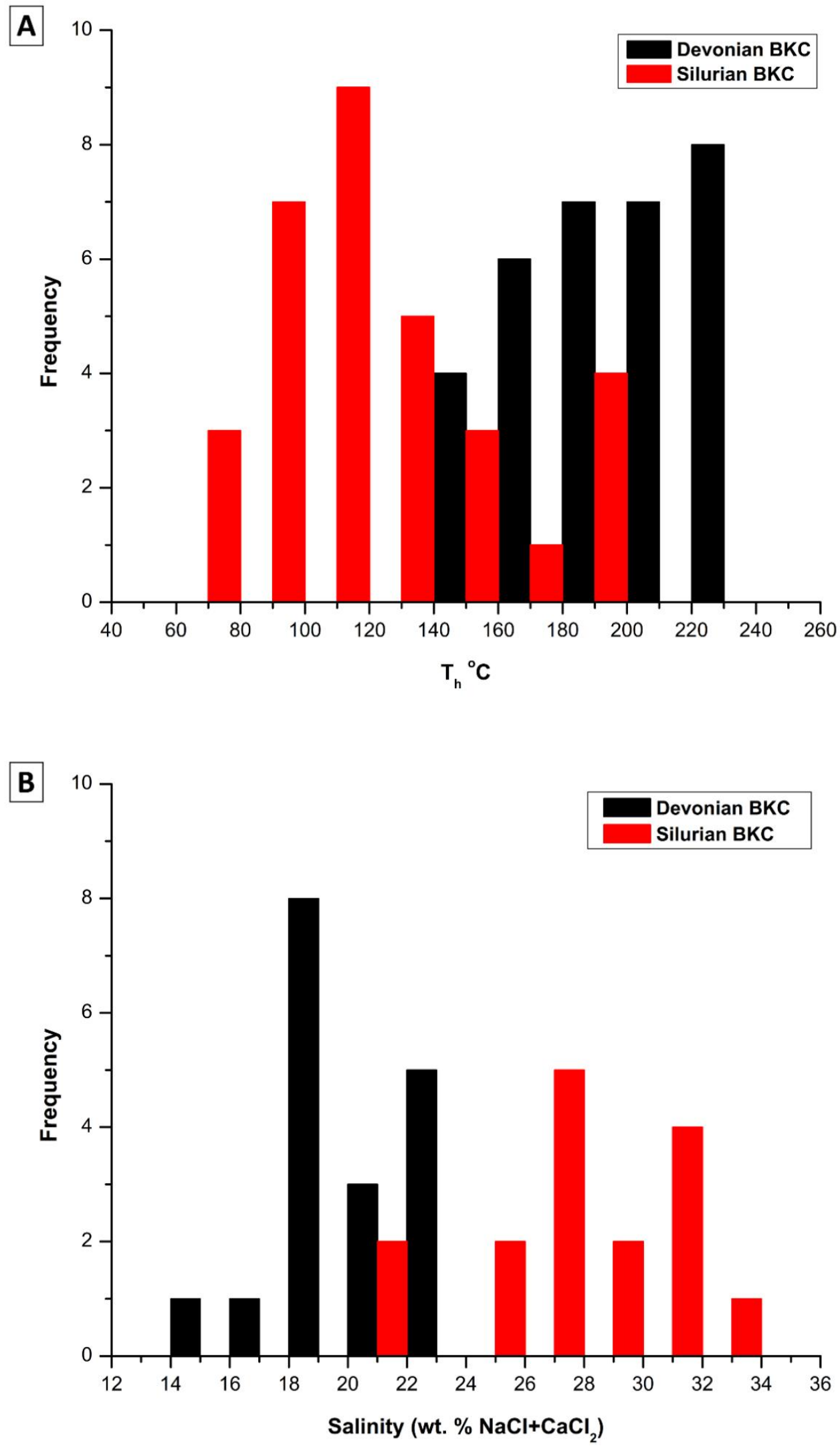

Figure 16. Histogram plots of (A) homogenization temperature and (B) salinity for calcite cement (BKC) in Silurian and Devonian formations. 
Table 4. Fluid inclusions results.

\begin{tabular}{|c|c|c|c|c|c|c|c|}
\hline Sample & Age & Host Mineral & Occurrence & Size $(\mu \mathrm{m})$ & $\mathrm{T}_{\mathrm{h}}\left({ }^{\circ} \mathrm{C}\right)$ & $\mathrm{Tm}_{\text {ice }}\left({ }^{\circ} \mathrm{C}\right)$ & Salinity \\
\hline $1-31-1$ & Silurian & RD2 & Cluster & 2 & 54.2 & & \\
\hline $1-31-2$ & Silurian & RD2 & Cluster & 3 & 55.1 & & \\
\hline $1-31-3$ & Silurian & RD2 & Cluster & 1 & 57.5 & & \\
\hline $1-31-4$ & Silurian & RD2 & Cluster & 7 & 100.4 & -20.3 & 22.58 \\
\hline $1-31-5$ & Silurian & RD2 & Cluster & 1 & 49.7 & & \\
\hline $1-31-6$ & Silurian & RD2 & Cluster & 6 & 118.9 & -22.3 & 23.89 \\
\hline $1-31-7$ & Silurian & RD2 & Cluster & 5 & 92.6 & -24.4 & 25.21 \\
\hline $1-31-8$ & Silurian & RD2 & Cluster & 5 & 97.5 & -21.4 & 23.31 \\
\hline $1-31-9$ & Silurian & RD2 & Cluster & 4 & 88.9 & & \\
\hline $1-31-10$ & Silurian & RD2 & Isolated & 5 & 85.9 & -19.5 & 22.03 \\
\hline $1-31-11$ & Silurian & RD2 & Isolated & 2 & 71.4 & & \\
\hline $1-31-12$ & Silurian & RD2 & Isolated & 10 & 134.1 & -23.6 & 24.71 \\
\hline $1-31-13$ & Silurian & RD2 & Crystal growth & 2 & 91.5 & & \\
\hline $1-31-14$ & Silurian & RD2 & Crystal growth & 1 & 92.8 & & \\
\hline $1-31-15$ & Silurian & RD2 & Crystal growth & 1 & 93.6 & & \\
\hline $1-31-16$ & Silurian & RD2 & Crystal growth & 1 & 84.7 & & \\
\hline $1-31-17$ & Silurian & RD2 & Crystal growth & 1 & 89.6 & & \\
\hline $1-31-18$ & Silurian & RD2 & Crystal growth & 4 & 97.1 & -21.2 & 23.18 \\
\hline $1-31-19$ & Silurian & RD2 & Crystal growth & 2 & 96.4 & & \\
\hline $1-31-20$ & Silurian & RD2 & Crystal growth & 1 & 99.8 & & \\
\hline $1-31-21$ & Silurian & RD2 & Crystal growth & 6 & 97.3 & -20.2 & 22.51 \\
\hline $8-13-31$ & Silurian & RD2 & Crystal growth & 3 & 111.4 & -19.9 & 22.31 \\
\hline $1-31-22$ & Silurian & $\mathrm{BKC}$ & Isolated & 6 & 159.9 & & \\
\hline $1-31-23$ & Silurian & BKC & Isolated & 5 & 184.7 & -25.3 & 25.76 \\
\hline 8-13-1 & Silurian & $\mathrm{BKC}$ & Short trail & 7 & 119.3 & -32.7 & 30.42 \\
\hline $8-13-2$ & Silurian & $\mathrm{BKC}$ & Short trail & 8 & 118.1 & -33.5 & 30.97 \\
\hline $8-13-3$ & Silurian & BKC & Short trail & 6 & 109.3 & -29.4 & 28.28 \\
\hline $8-13-4$ & Silurian & $\mathrm{BKC}$ & Cluster & 4 & 106.4 & & \\
\hline $8-13-5$ & Silurian & $\mathrm{BKC}$ & Cluster & 4 & 145.4 & & \\
\hline $8-13-6$ & Silurian & BKC & Cluster & 2 & 79.4 & & \\
\hline $8-13-7$ & Silurian & $\mathrm{BKC}$ & Cluster & 2 & 95.7 & & \\
\hline $8-13-8$ & Silurian & $\mathrm{BKC}$ & Cluster & 3 & 130.1 & & \\
\hline $8-13-9$ & Silurian & $\mathrm{BKC}$ & Cluster & 2 & 149.7 & & \\
\hline $8-13-10$ & Silurian & $\mathrm{BKC}$ & Cluster & 2 & 172.3 & & \\
\hline 8-13-11 & Silurian & $\mathrm{BKC}$ & Isolated & 10 & 115.9 & -31.8 & 29.82 \\
\hline $8-13-12$ & Silurian & $\mathrm{BKC}$ & Crystal growth & 13 & 81.8 & -28.7 & 27.85 \\
\hline $8-13-13$ & Silurian & BKC & Crystal growth & 18 & 96.2 & -32.6 & 30.35 \\
\hline 8-13-14 & Silurian & $\mathrm{BKC}$ & Crystal growth & 15 & 93.3 & -28.2 & 27.54 \\
\hline $8-13-15$ & Silurian & $\mathrm{BKC}$ & Crystal growth & 6 & 89.4 & & \\
\hline $8-13-16$ & Silurian & $\mathrm{BKC}$ & Crystal growth & 5 & 81.6 & & \\
\hline $8-13-17$ & Silurian & $\mathrm{BKC}$ & Isolated & 8 & 73.4 & -26.9 & 26.74 \\
\hline 8-13-18 & Silurian & $\mathrm{BKC}$ & Isolated & 6 & 84.7 & -27.1 & 26.86 \\
\hline $8-13-19$ & Silurian & BKC & Isolated & 2 & 104.7 & & \\
\hline $8-13-20$ & Silurian & $\mathrm{BKC}$ & Isolated & 3 & 103.5 & & \\
\hline $8-13-21$ & Silurian & $\mathrm{BKC}$ & Isolated & 2 & 122.6 & & \\
\hline $8-13-22$ & Silurian & BKC & Crystal growth & 10 & 113.8 & -35.4 & 32.33 \\
\hline $1-28-6$ & Silurian & $\mathrm{BKC}$ & Isolated & 12 & 115.2 & -33.1 & 30.69 \\
\hline $1-28-7$ & Silurian & $\mathrm{BKC}$ & Cluster & 3 & 123.3 & & \\
\hline $1-28-8$ & Silurian & BKC & Cluster & 4 & 189 & -18.6 & 21.40 \\
\hline $1-28-9$ & Silurian & $\mathrm{BKC}$ & Cluster & 4 & 139.7 & -19.1 & 21.75 \\
\hline $1-28-10$ & Silurian & $\mathrm{BKC}$ & Isolated & 6 & 182.8 & & \\
\hline $1-28-11$ & Silurian & BKC & Isolated & 6 & 194.3 & & \\
\hline $1-28-12$ & Silurian & BKC & Isolated & 4 & 124.7 & -22.8 & 24.21 \\
\hline $1-28-13$ & Silurian & $\mathrm{BKC}$ & Isolated & 10 & 70.2 & -25.9 & 26.13 \\
\hline 8-13-19 & Silurian & $\mathrm{SD}$ & Crystal growth & 5 & 122.6 & & \\
\hline $8-13-20$ & Silurian & SD & Crystal growth & 5 & 123.4 & & \\
\hline $8-13-21$ & Silurian & SD & Crystal growth & 3 & 142.7 & & \\
\hline
\end{tabular}


Table 4. Cont.

\begin{tabular}{|c|c|c|c|c|c|c|c|}
\hline Sample & Age & Host Mineral & Occurrence & Size $(\mu \mathrm{m})$ & $\mathrm{T}_{\mathrm{h}}\left({ }^{\circ} \mathrm{C}\right)$ & $\operatorname{Tm}_{\text {ice }}\left({ }^{\circ} \mathrm{C}\right)$ & Salinity \\
\hline $8-13-22$ & Silurian & SD & Crystal growth & 4 & 193.4 & & \\
\hline $8-13-23$ & Silurian & SD & Scattered & 5 & 121.8 & -35.8 & 32.63 \\
\hline $8-13-24$ & Silurian & SD & Scattered & 6 & 125.9 & -33.2 & 30.76 \\
\hline $8-13-25$ & Silurian & SD & Scattered & 2 & 117.16 & & \\
\hline $8-13-26$ & Silurian & SD & Scattered & 3 & 145.1 & & \\
\hline $8-13-27$ & Silurian & SD & Scattered & 2 & 115.5 & & \\
\hline $8-13-28$ & Silurian & SD & Scattered & 2 & 118.1 & & \\
\hline 8-13-29 & Silurian & SD & Scattered & 4 & 119.5 & -29.1 & 28.09 \\
\hline $8-13-30$ & Silurian & SD & Isolated & 10 & 102.3 & -24.5 & 25.27 \\
\hline $8-13-31$ & Silurian & SD & Isolated & 15 & 110.2 & -28.6 & 27.78 \\
\hline 8-13-32 & Silurian & SD & Crystal growth & 6 & 112.5 & -27.1 & 26.86 \\
\hline $8-13-33$ & Silurian & SD & Crystal growth & 7 & 123.2 & -30.9 & 29.23 \\
\hline $8-13-34$ & Silurian & SD & Crystal growth & 11 & 105.2 & -28.2 & 27.54 \\
\hline $8-13-35$ & Silurian & SD & Crystal growth & 5 & 115.9 & -31.6 & 29.69 \\
\hline $8-13-36$ & Silurian & SD & Crystal growth & 4 & 108.9 & & \\
\hline $8-13-37$ & Silurian & SD & Crystal growth & 10 & 117.3 & -28.6 & 27.78 \\
\hline $8-13-38$ & Silurian & SD & Crystal growth & 9 & 103.4 & -27.9 & 27.35 \\
\hline $8-13-39$ & Silurian & SD & Crystal growth & 6 & 101.2 & -31.1 & 29.36 \\
\hline $8-13-40$ & Silurian & SD & Crystal growth & 13 & 127.5 & -29.9 & 28.60 \\
\hline $8-13-41$ & Silurian & SD & Crystal growth & 3 & 125.9 & -32.8 & 30.49 \\
\hline $8-13-42$ & Silurian & SD & Crystal growth & 4 & 132.7 & & \\
\hline $1-28-1$ & Silurian & SD & Crystal growth & 6 & 112.3 & -26.8 & 26.68 \\
\hline $1-28-2$ & Silurian & SD & Crystal growth & 8 & 120.5 & -27.1 & 26.86 \\
\hline $1-28-3$ & Silurian & SD & Crystal growth & 5 & 126.6 & -27.8 & 27.29 \\
\hline $1-28-4$ & Silurian & SD & Crystal growth & 3 & 130.3 & & \\
\hline $1-28-5$ & Silurian & SD & Crystal growth & 3 & 136.4 & & \\
\hline $1-28-6$ & Silurian & SD & Crystal growth & 5 & 125.8 & -28.4 & 27.66 \\
\hline $1-28-7$ & Silurian & SD & Crystal growth & 7 & 186.6 & -33.7 & 31.11 \\
\hline $8-4-1$ & Devonian & RD2 & Crystal growth & 3 & 101.1 & & \\
\hline $8-4-2$ & Devonian & RD2 & Isolated & 5 & 87.5 & -18.6 & 21.40 \\
\hline $8-4-2$ & Devonian & RD2 & Cluster & 2 & 85.3 & & \\
\hline $8-4-2$ & Devonian & RD2 & Cluster & 4 & 79.6 & -17.9 & 20.89 \\
\hline $8-4-2$ & Devonian & RD2 & Cluster & 1 & 88.1 & & \\
\hline $8-4-2$ & Devonian & RD2 & Cluster & 6 & 77.8 & -15.4 & 18.96 \\
\hline $8-4-2$ & Devonian & RD2 & Cluster & 4 & 84.3 & -17.8 & 20.82 \\
\hline $8-4-2$ & Devonian & RD2 & Cluster & 2 & 75.4 & & \\
\hline $1-3-2-1$ & Devonian & RD2 & Isolated & 5 & 76.9 & -19.2 & 21.82 \\
\hline $1-3-2-2$ & Devonian & RD2 & Isolated & 3 & 85.2 & & \\
\hline $1-3-2-3$ & Devonian & RD2 & Cluster & 4 & 93.3 & -17.4 & 20.52 \\
\hline $1-3-2-4$ & Devonian & RD2 & Isolated & 6 & 79.1 & -18.3 & 21.19 \\
\hline $1-3-2-5$ & Devonian & RD2 & Isolated & 1 & 71.4 & & \\
\hline $1-3-2-6$ & Devonian & RD2 & Isolated & 2 & 102.3 & & \\
\hline $1-3-2-7$ & Devonian & RD2 & Isolated & 1 & 76.3 & & \\
\hline $1-3-2-8$ & Devonian & RD2 & Isolated & 1 & 69.9 & & \\
\hline $1-3-2-9$ & Devonian & RD2 & Isolated & 2 & 81.1 & & \\
\hline 8-1-1. & Devonian & BKC & Isolated & 8 & 173.5 & -11.2 & 15.17 \\
\hline $8-1-2$ & Devonian & BKC & Cluster & 10 & 205.1 & & \\
\hline $8-1-3$ & Devonian & BKC & Cluster & 2 & 166.9 & & \\
\hline $8-1-4$ & Devonian & BKC & Crystal growth & 8 & 175 & & \\
\hline $8-1-5$ & Devonian & $\mathrm{BKC}$ & Crystal growth & 8 & 208.4 & -15.6 & 19.13 \\
\hline $8-1-6$ & Devonian & $\mathrm{BKC}$ & Trail & 2 & 154.1 & & \\
\hline $8-1-7$ & Devonian & $\mathrm{BKC}$ & Trail & 2 & 157.9 & & \\
\hline $8-1-8$ & Devonian & BKC & Trail & 2 & 163.2 & & \\
\hline $8-1-9$ & Devonian & $\mathrm{BKC}$ & Scattered & 8 & 183.1 & -14.8 & 18.47 \\
\hline 8-1-10. & Devonian & BKC & Scattered & 8 & 208.6 & -15.2 & 18.80 \\
\hline 8-1-11. & Devonian & BKC & Scattered & 4 & 221.2 & & \\
\hline 8-1-12. & Devonian & BKC & Scattered & 3 & 182.4 & & \\
\hline 8-1-13. & Devonian & BKC & Cluster & 6 & 199.8 & -19.9 & 22.31 \\
\hline 8-1-14. & Devonian & BKC & Scattered & 3 & 168.3 & & \\
\hline 8-1-15. & Devonian & BKC & Cluster & 5 & 237.8 & & \\
\hline
\end{tabular}


Table 4. Cont.

\begin{tabular}{cccccccc}
\hline Sample & Age & Host Mineral & Occurrence & Size $(\mu \mathbf{m})$ & $\mathbf{T}_{\mathbf{h}}\left({ }^{\circ} \mathbf{C}\right)$ & $\mathbf{T m}_{\text {ice }}\left({ }^{\circ} \mathbf{C}\right)$ & Salinity \\
\hline 8-1-16. & Devonian & BKC & Cluster & 7 & 180.2 & -20.1 & 22.44 \\
$8-1-17$. & Devonian & BKC & Cluster & 8 & 225.4 & -19.4 & 21.96 \\
8-1-18. & Devonian & BKC & Cluster & 5 & 225.8 & & \\
8-1-19. & Devonian & BKC & Isolated & 7 & 196.4 & -21.4 & 23.31 \\
8-1-20. & Devonian & BKC & Trail & 5 & 207.1 & & \\
8-1-21. & Devonian & BKC & Isolated & 8 & 165.9 & -15.9 & 19.37 \\
8-1-22. & Devonian & BKC & Trail & 8 & 237.9 & -16.2 & 19.60 \\
8-1-23. & Devonian & BKC & Isolated & 8 & 231.1 & -19.1 & 21.75 \\
8-1-24. & Devonian & BKC & Isolated & 7 & 209.8 & -22.4 & 23.95 \\
8-1-25. & Devonian & BKC & Scattered & 8 & 227.1 & -12.9 & 16.80 \\
8-1-26. & Devonian & BKC & Scattered & 4 & 146.2 & & \\
8-1-27. & Devonian & BKC & Scattered & 4 & 188.6 & & 19.76 \\
8-1-28. & Devonian & BKC & Isolated & 6 & 200.8 & -16.4 & 19.60 \\
8-1-29. & Devonian & BKC & Isolated & 6 & 195.5 & -16.2 & 20.82 \\
8-1-30. & Devonian & BKC & Isolated & 7 & 223.9 & -17.8 & 18.38 \\
8-1-31. & Devonian & BKC & Isolated & 4 & 154.3 & -14.7 & 22.10 \\
8-1-32. & Devonian & BKC & Isolated & 9 & 214.5 & -19.6 & \\
\hline
\end{tabular}

\subsubsection{Major, Minor and Trace Elements Analysis}

\section{Major Elements and Dolomite Stoichiometry}

The concentrations of the major elements, calcium and magnesium, were determined by ICP-MS analysis for dolomite and calcite phases to establish their stoichiometry. Ideal or stoichiometric dolomite would be characterized by the equal molar percentage of $\mathrm{MgCO}_{3}$ and $\mathrm{CaCO}_{3}$ and would be less soluble and more stable compared to non-stoichiometric dolomite [53]. In contrast, non-stoichiometric dolomite will have more $\mathrm{Ca}$ than $\mathrm{Mg}$ and because of its heterogeneous structure and composition is unstable and dissolve more rapidly.

All the dolomite types recognized petrographically were sampled and analyzed without any contamination from calcite components for both age groups with the only exception for the selective replacive dolomite (RD3) which could not be sampled without possible contamination by calcite or other dolomite phases in the Silurian specimens. With rare exceptions, all types of dolomite analyzed in this study were non-stoichiometric in both age groups (Table 5) with variable proportions of $\mathrm{MgCO}_{3}$ and $\mathrm{CaCO}_{3}$.

In both age group RD1 in non-stoichiometric but results less stoichiometric in Silurian formation compared to Devonian samples. Pervasive replacive micro to fine crystalline dolomite (RD1) ranges from 48.34 to 59.36 mole $\% \mathrm{CaCO}_{3}$ (average: $55.19 \pm 3.73$ ) and from 51.78 to 60.77 mole $\% \mathrm{CaCO}_{3}$ (average: $57.71 \pm 3.04)$ for Silurian and Devonian formations, respectively $\left(n_{S}=11\right.$ and $\left.n_{D}=7\right)$.

$\mathrm{RD} 2$ shows comparable values of mole $\% \mathrm{CaCO}_{3}$, but it is slightly more calcian in Devonian formations. Pervasive replacive medium crystalline dolomite (RD2) ranges from 56.11 to 62.12 mole \% $\mathrm{CaCO}_{3}$ (average: $58.04 \pm 2.4$ ) and from 58.39 to 61.57 mole $\% \mathrm{CaCO}_{3}$ (average: $59.71 \pm 1.16$ ) for Silurian and Devonian formations, respectively $\left(\mathrm{n}_{\mathrm{S}}=4\right.$ and $\left.\mathrm{n}_{\mathrm{D}}=4\right)$.

Selective replacive medium crystalline dolomite (RD3) ranges from 47.93 to 59.96 mole $\% \mathrm{CaCO}_{3}$ (average: $53.55 \pm 4.94)$ in Devonian formations $\left(\mathrm{n}_{\mathrm{D}}=3\right)$.

Saddle dolomite cement (SD), only observed and sampled from Silurian formations $\left(\mathrm{n}_{\mathrm{S}}=2\right)$, ranges from 63.47 to 67.00 mole $\% \mathrm{CaCO}_{3}$ (average: $65.23 \pm 1.77$ ). 
Table 5. Major, minor and trace elements results.

\begin{tabular}{|c|c|c|c|c|c|c|c|}
\hline Sample & Age & Type & $\begin{array}{c}\mathrm{MgCO}_{3} \\
(\mathrm{~mole} \%)\end{array}$ & $\begin{array}{c}\mathrm{CaCO}_{3} \\
(\text { mole \%) }\end{array}$ & $\begin{array}{c}\text { Mn } \\
(p p m)\end{array}$ & $\begin{array}{c}\text { Fe } \\
(\mathrm{ppm})\end{array}$ & $\begin{array}{c}\mathrm{Sr} \\
(\mathrm{ppm})\end{array}$ \\
\hline $1-15 a$ & Silurian & RD1 & 43.0 & 57.0 & 42.5 & 678.9 & 89.3 \\
\hline $1-16 a$ & Silurian & RD1 & 41.6 & 58.4 & 62.1 & 599.1 & 90.1 \\
\hline $1-17 a$ & Silurian & RD1 & 42.0 & 58.0 & 34.2 & 606.3 & 70.2 \\
\hline $1-18$ & Silurian & RD1 & 46.8 & 53.2 & 197.6 & 3458.5 & 71.9 \\
\hline $1-20$ & Silurian & RD1 & 40.6 & 59.4 & 130.2 & 2564.8 & 72.4 \\
\hline $1-21$ & Silurian & RD1 & 48.7 & 51.3 & 67.9 & 339.3 & 71.9 \\
\hline $1-31 a$ & Silurian & RD1 & 49.8 & 50.2 & 446.7 & 2984.0 & 97.7 \\
\hline $8-5 a$ & Silurian & RD1 & 51.7 & 48.3 & 208.9 & 3515.8 & 94.8 \\
\hline $8-6$ & Silurian & RD1 & 41.2 & 58.8 & 157.3 & 3276.2 & 81.2 \\
\hline $8-8$ & Silurian & RD1 & 45.6 & 54.4 & 100.1 & 617.7 & 107.9 \\
\hline $8-13 a$ & Silurian & RD1 & 41.8 & 58.2 & 552.2 & 4020.5 & 80.2 \\
\hline $1-16 b$ & Silurian & RD2 & 43.9 & 56.1 & 66.3 & 809.7 & 81.2 \\
\hline $1-24$ & Silurian & RD2 & 37.9 & 62.1 & 103.7 & 6261.1 & 166.3 \\
\hline $1-31 b$ & Silurian & RD2 & 42.6 & 57.4 & 702.5 & 5183.0 & 70.7 \\
\hline $8-13 b$ & Silurian & RD2 & 43.5 & 56.5 & 748.4 & 5929.5 & 71.9 \\
\hline $1-28 a$ & Silurian & SD & 33.0 & 67.0 & 214.6 & $20,374.0$ & 81.8 \\
\hline $8-13 c$ & Silurian & SD & 36.5 & 63.5 & 1436.5 & $18,005.3$ & 111.2 \\
\hline $1-1 \mathrm{a}$ & Devonian & RD1 & 48.2 & 51.8 & 30.1 & 81.3 & 46.8 \\
\hline $1-3-1 a$ & Devonian & RD1 & 39.5 & 60.5 & 29.1 & 80.6 & 58.4 \\
\hline $1-5 a$ & Devonian & RD1 & 39.3 & 60.7 & 46.1 & 171.2 & 81.9 \\
\hline $1-5 b$ & Devonian & RD1 & 43.4 & 56.6 & 40.7 & 148.4 & 66.3 \\
\hline $1-7 a$ & Devonian & RD1 & 43.7 & 56.3 & 35.7 & 112.2 & 72.6 \\
\hline $8-1 a$ & Devonian & RD1 & 39.2 & 60.8 & 25.8 & 90.0 & 62.0 \\
\hline $8-4 a$ & Devonian & RD1 & 42.7 & 57.3 & 54.2 & 690.5 & 67.3 \\
\hline $1-3-2 a$ & Devonian & RD2 & 40.4 & 59.6 & 32.9 & 83.0 & 60.3 \\
\hline $1-4 a$ & Devonian & RD2 & 40.7 & 59.3 & 39.8 & 89.6 & 93.9 \\
\hline $1-7 \mathrm{~b}$ & Devonian & RD2 & 41.6 & 58.4 & 37.4 & 117.4 & 71.7 \\
\hline $8-4 b$ & Devonian & RD2 & 38.4 & 61.6 & 59.9 & 756.1 & 79.4 \\
\hline $1-3-2 b$ & Devonian & RD3 & 47.2 & 52.8 & 40.8 & 360.9 & 65.7 \\
\hline 1-6a & Devonian & RD3 & 40.0 & 60.0 & 42.5 & 173.0 & 89.1 \\
\hline $8-4 c$ & Devonian & RD3 & 52.1 & 47.9 & 59.0 & 724.8 & 78.9 \\
\hline
\end{tabular}

Minor and Trace Elements: Iron, Manganese and Strontium

The results of trace elements in dolomitic phases are presented in Table 5.

RD1 sampled from Silurian formations show higher contents of Mn, Fe and $\mathrm{Sr}$ to Devonian samples. Pervasive replacive fine crystalline dolomite matrix RD1 in Silurian rocks $(\mathrm{n}=11)$ is characterized by Mn contents between 34.2 to $552.2 \mathrm{ppm}$ (average: $181.5 \pm 161.5 \mathrm{ppm}$ ), Fe between 339.3 to 4020.5 ppm (average: $2060.1 \pm 1404.6$ ) and Sr between 70.2 to 107.9 ppm (average: $85.6 \pm 11.9$ ), whereas in Devonian rocks ( $\mathrm{n}=7$ ) Mn ranges between 25.8 to $54.2 \mathrm{ppm}$ (average: $37.4 \pm 9.5$ ), Fe between 80.6 to 690.5 ppm (average: $196.3 \pm 204.3$ ) and Sr between 46.8 to 81.9 ppm (average: $65 \pm 10.2$ ).

Silurian RD2 samples show higher contents of Mn, Fe and Sr compared to Devonian samples. Pervasive replacive medium crystalline dolomite matrix RD2 in Silurian rocks $(n=4)$ is characterized by Mn contents between 66.3 to $748.4 \mathrm{ppm}$ (average: $405.2 \pm 320.9$ ), Fe between 809.7 to $6261.1 \mathrm{ppm}$ (average: $4545.8 \pm 2192.1$ ) and Sr between 70.7 to $166.3 \mathrm{ppm}$ (average: $97.5 \pm 39.9$ ), whereas in Devonian rocks $(n=4)$ Mn ranges between 32.9 to 59.9 ppm (average: $42.5 \pm 10.3$ ), Fe between 83 to 756.1 ppm (average: $261.5 \pm 285.8$ ) and $\mathrm{Sr}$ between 60.2 to $93.8 \mathrm{ppm}$ (average: $76.3 \pm 12.2$ ). Selective replacive medium crystalline dolomite matrix (RD3) sampled from Devonian formations only $(\mathrm{n}=3)$ and is characterized by Mn contents between 59 to 40.8 ppm (average: $47.5 \pm 8.2$ ), Fe between 724.8 to 173 ppm (average: $419.6 \pm 229$ ), and Sr between 89.1 to 65.7 ppm (average: $77.9 \pm 9.6$ )

Values of trace elements in saddle dolomite cement (SD) encountered exclusively in Silurian formations $(n=2)$ is characterized by Mn contents between 214.5 to 1436.5 ppm (average: $825.5 \pm 611$ ), 
Fe between 18005.3 to 20373.9 ppm (average: $19189.7 \pm 1184.3$ ), and Sr between 81.8 to $111.2 \mathrm{ppm}$ (average: $96.5 \pm 14.7$ ).

Silurian dolomites have higher Mn, Fe and Sr content than Devonian dolomites and also the progressive increase in $\mathrm{Fe}$ and $\mathrm{Mn}$ in the successive generations.

In addition to the previously mentioned results, samples $(n=10$ and $n=5)$ from early and late calcite cement were analyzed to establish their trace elements concentrations.

Isopachous calcite cement (ISC) observed only in Silurian formations $(\mathrm{n}=2)$ is characterized by Mn contents between 41.9 to 48.2 ppm (average: $45.1 \pm 3.2$ ), Fe between 164.8 to 230.5 ppm (average: $197.7 \pm 32.8$ ) and Sr between 177.1 to $244.3 \mathrm{ppm}$ (average: $210.7 \pm 33.6$ ).

Syntaxial overgrowth calcite cement (SXC) in Silurian rocks $(n=2)$ show higher contents of Mn, Fe compared with respective values obtained from Devonian samples, but lower Sr concentrations. It is characterized by Mn contents between 272.1 to $589.23 \mathrm{ppm}$ (average: $430.7 \pm 158.6$ ), Fe between 617.7 to $1124.5 \mathrm{ppm}$ (average: $871.1 \pm 253.4$ ) and Sr between 230.8 to $244.3 \mathrm{ppm}$ (average: $237.6 \pm 6.7$ ), whereas in Devonian rocks ( $\mathrm{n}=3$ ) Mn ranges between 15.7 to $20.3 \mathrm{ppm}$ (average: $17.9 \pm 1.9$ ), Fe between 41 to 51.4 ppm (average: $47.4 \pm 4.6$ ) and $\mathrm{Sr}$ between 239.1 to $498.7 \mathrm{ppm}$ (average: $333 \pm 117.5$ ).

A single measurement in each age group of drusy calcite cement (DC) show values of $\mathrm{Mn}$ : 36.5 ppm and 116.2 ppm, Fe: 401 ppm and 217.67 ppm, and Sr: 116.8 ppm and 1425 ppm for the Silurian $(\mathrm{n}=1)$ and Devonian $(\mathrm{n}=1)$ samples, respectively.

Late-stage blocky calcite cement (BKC) sampled from Silurian formations show significantly higher contents of $\mathrm{Mn}, \mathrm{Fe}$, and $\mathrm{Sr}$ compared to Devonian samples. Trace element values from Silurian samples $\left(\mathrm{n}_{\mathrm{S}}=5\right)$ is characterized by contents of Mn between 82.1 and $754.2 \mathrm{ppm}$ (average: $225.9 \pm 264.6$ ), Fe between 79.2 to $2097.6 \mathrm{ppm}$ (average: $1036.5 \pm 811.4$ ) and Sr between 164.6 to $538.6 \mathrm{ppm}$ (average: $317.3 \pm 144$ ), whereas results from the single pure sample available of blocky calcite cement from Devonian formations show values of Mn: 35.9 ppm, Fe: 8.7 ppm and Sr: 643.9 ppm. BKC

\subsubsection{Rare Earth Elements (REE)}

Selected samples of pervasive replacive fine crystalline dolomite matrix (RD1), pervasive replacive medium crystalline dolomite matrix (RD2), saddle dolomite cement (SD) and blocky calcite cement (BKC) were analyzed for REEs concentrations from Silurian formations. In addition to the selected samples of pervasive replacive fine-crystalline dolomite matrix (RD1), pervasive replacive, medium crystalline dolomite matrix (RD2), selective replacive medium crystalline dolomite matrix (RD3) and blocky calcite cement (BKC) were analyzed for REEs concentrations from Devonian successions (Table 6).

Replacive dolomite RD1 and RD2 sampled from Silurian formations show sub-parallel trends compared to the pattern of Silurian brachiopods shown by Azmy et al. [54] but with substantial differences from Devonian patterns, Silurian dolomite trends are characterized by a minor negative La anomaly and both cases of positive and negative Ce anomalies (Figure 17A,B). Both types of dolomite RD1 and RD2 exhibit higher average $\Sigma$ REE $(11.88 \pm 6.25 \mathrm{ppm}$, and $10.62 \pm 8.92 \mathrm{ppm}$, respectively) compared with the average of Silurian brachiopods (2.21 ppm) shown by Azmy et al. [55]. Saddle dolomite (SD) and blocky calcite cement (BKC) show similar REE shale-normalized trends (Figure 17A,B) with average $\Sigma$ REE $(47.06 \pm 41.95 \mathrm{ppm}$ and $28.83 \pm 24.47 \mathrm{ppm}$, respectively) and both significantly differ from the Silurian Brachiopods REE patterns. As shown in Figure 17, SD and BKC present both negative La and Ce anomalies (Figure 17B) as well as a slight negative Eu anomaly (Figure 17A).

All the dolomite and late calcite samples from Devonian formations exhibit shale-normalized patterns comparable to those of modern warm water brachiopods (Figure 18A). 
Table 6. Rare earth elements (REE) results.

\begin{tabular}{|c|c|c|c|c|c|c|c|c|c|c|c|c|c|c|c|c|c|}
\hline Sample & Age & Type & $\begin{array}{c}\mathrm{La} \\
(\mathrm{ppm})\end{array}$ & $\begin{array}{c}\mathrm{Ce} \\
(\mathrm{ppm})\end{array}$ & $\begin{array}{c}\operatorname{Pr} \\
(\mathbf{p p m})\end{array}$ & $\begin{array}{c}\mathrm{Nd} \\
(\mathrm{ppm})\end{array}$ & $\begin{array}{c}\mathrm{Sm} \\
(\mathrm{ppm})\end{array}$ & $\begin{array}{c}\mathrm{Eu} \\
(\mathrm{ppm})\end{array}$ & $\underset{(\mathrm{ppm})}{\mathrm{Gd}}$ & $\begin{array}{c}\mathrm{Tb} \\
(\mathrm{ppm})\end{array}$ & $\begin{array}{c}\text { Dy } \\
\text { (ppm) }\end{array}$ & $\begin{array}{c}\text { Ho } \\
(\mathrm{ppm})\end{array}$ & $\begin{array}{c}\text { Er } \\
(\mathrm{ppm})\end{array}$ & $\underset{(\mathrm{ppm})}{\operatorname{Tm}}$ & $\begin{array}{c}\mathrm{Yb} \\
(\mathrm{ppm})\end{array}$ & $\begin{array}{c}\mathrm{Lu} \\
(\mathrm{ppm})\end{array}$ & $\begin{array}{l}\Sigma \mathrm{REE} \\
\text { (ppm) }\end{array}$ \\
\hline $1-15 a$ & Silurian & RD1 & 1.51 & 3.42 & 0.44 & 1.65 & 0.36 & 0.09 & 0.31 & 0.05 & 0.26 & 0.05 & 0.16 & 0.02 & 0.12 & 0.02 & 8.46 \\
\hline $1-16 a$ & Silurian & RD1 & 3.80 & 9.17 & 1.16 & 4.22 & 0.84 & 0.16 & 0.76 & 0.11 & 0.62 & 0.11 & 0.33 & 0.04 & 0.26 & 0.04 & 21.62 \\
\hline $1-17 a$ & Silurian & RD1 & 0.78 & 1.42 & 0.15 & 0.52 & 0.10 & 0.02 & 0.10 & 0.01 & 0.06 & 0.01 & 0.04 & 0.00 & 0.03 & 0.00 & 3.25 \\
\hline $1-18$ & Silurian & RD1 & 1.76 & 4.02 & 0.51 & 2.07 & 0.43 & 0.08 & 0.41 & 0.05 & 0.28 & 0.05 & 0.12 & 0.01 & 0.07 & 0.01 & 9.88 \\
\hline $1-20$ & Silurian & RD1 & 3.97 & 9.62 & 1.16 & 4.58 & 1.05 & 0.25 & 1.06 & 0.15 & 0.80 & 0.15 & 0.41 & 0.05 & 0.27 & 0.04 & 23.55 \\
\hline $1-21$ & Silurian & RD1 & 0.87 & 1.99 & 0.23 & 0.90 & 0.16 & 0.05 & 0.17 & 0.02 & 0.13 & 0.02 & 0.07 & 0.01 & 0.06 & 0.00 & 4.68 \\
\hline $1-31 a$ & Silurian & RD1 & 2.06 & 4.23 & 0.54 & 2.04 & 0.41 & 0.10 & 0.42 & 0.06 & 0.32 & 0.06 & 0.19 & 0.02 & 0.14 & 0.02 & 10.62 \\
\hline $8-5 a$ & Silurian & RD1 & 2.19 & 5.21 & 0.64 & 2.40 & 0.47 & 0.11 & 0.50 & 0.06 & 0.35 & 0.07 & 0.18 & 0.02 & 0.12 & 0.02 & 12.33 \\
\hline $8-6$ & Silurian & RD1 & 2.75 & 6.99 & 0.87 & 3.46 & 0.75 & 0.19 & 0.82 & 0.12 & 0.64 & 0.12 & 0.30 & 0.04 & 0.20 & 0.03 & 17.27 \\
\hline $8-8$ & Silurian & RD1 & 1.17 & 2.82 & 0.35 & 1.34 & 0.27 & 0.06 & 0.30 & 0.04 & 0.22 & 0.04 & 0.11 & 0.01 & 0.12 & 0.01 & 6.86 \\
\hline $8-13 a$ & Silurian & RD1 & 2.42 & 4.90 & 0.60 & 2.19 & 0.48 & 0.10 & 0.46 & 0.07 & 0.39 & 0.08 & 0.25 & 0.02 & 0.16 & 0.02 & 12.13 \\
\hline $1-16 b$ & Silurian & RD2 & 3.64 & 9.45 & 1.23 & 4.86 & 0.88 & 0.18 & 0.86 & 0.12 & 0.65 & 0.12 & 0.36 & 0.05 & 0.23 & 0.03 & 22.67 \\
\hline $1-23 b$ & Silurian & RD2 & 0.28 & 0.50 & 0.05 & 0.26 & 0.05 & 0.01 & 0.05 & 0.01 & 0.04 & 0.01 & 0.02 & 0.00 & 0.02 & 0.00 & 1.30 \\
\hline $1-24$ & Silurian & RD2 & 0.32 & 0.69 & 0.09 & 0.35 & 0.06 & 0.01 & 0.07 & 0.01 & 0.07 & 0.02 & 0.04 & 0.01 & 0.02 & 0.01 & 1.77 \\
\hline $1-31 b$ & Silurian & RD2 & 2.87 & 6.52 & 0.80 & 2.80 & 0.49 & 0.12 & 0.48 & 0.06 & 0.37 & 0.06 & 0.21 & 0.03 & 0.15 & 0.02 & 14.98 \\
\hline $8-10 b$ & Silurian & RD2 & 0.29 & 0.53 & 0.06 & 0.23 & 0.06 & 0.01 & 0.06 & 0.01 & 0.05 & 0.01 & 0.03 & 0.00 & 0.02 & 0.00 & 1.37 \\
\hline $8-13 b$ & Silurian & RD2 & 3.32 & 7.82 & 0.97 & 3.79 & 0.73 & 0.13 & 0.67 & 0.08 & 0.48 & 0.09 & 0.24 & 0.04 & 0.23 & 0.03 & 18.61 \\
\hline $1-28 a$ & Silurian & SD & 0.36 & 0.77 & 0.09 & 0.39 & 0.07 & 0.02 & 0.04 & 0.01 & 0.05 & 0.01 & 0.02 & 0.00 & 0.02 & 0.00 & 1.85 \\
\hline $1-31 c$ & Silurian & SD & 5.75 & 16.24 & 2.14 & 8.07 & 1.39 & 0.23 & 1.06 & 0.13 & 0.68 & 0.11 & 0.33 & 0.04 & 0.21 & 0.03 & 36.41 \\
\hline $8-13 c$ & Silurian & SD & 19.39 & 47.98 & 5.92 & 20.35 & 3.42 & 0.44 & 2.30 & 0.27 & 1.34 & 0.23 & 0.69 & 0.08 & 0.45 & 0.06 & 102.93 \\
\hline $1-23 a$ & Silurian & ISC & 0.40 & 0.71 & 0.08 & 0.33 & 0.05 & 0.01 & 0.06 & 0.01 & 0.05 & 0.01 & 0.05 & 0.00 & 0.02 & 0.00 & 1.80 \\
\hline $8-10 a$ & Silurian & ISC & 0.20 & 0.39 & 0.05 & 0.20 & 0.04 & 0.01 & 0.04 & 0.01 & 0.03 & 0.01 & 0.02 & 0.00 & 0.02 & 0.00 & 1.01 \\
\hline $1-32$ & Silurian & SXC & 6.07 & 10.30 & 1.44 & 5.74 & 1.09 & 0.24 & 1.17 & 0.14 & 0.76 & 0.14 & 0.35 & 0.04 & 0.24 & 0.03 & 27.75 \\
\hline $1-33 a$ & Silurian & SXC & 3.86 & 7.09 & 0.94 & 3.92 & 1.08 & 0.26 & 1.42 & 0.20 & 1.39 & 0.29 & 0.93 & 0.12 & 0.80 & 0.10 & 22.42 \\
\hline $1-17 \mathrm{~b}$ & Silurian & DC & 1.22 & 2.08 & 0.23 & 0.82 & 0.15 & 0.04 & 0.12 & 0.02 & 0.10 & 0.01 & 0.05 & 0.01 & 0.03 & 0.01 & 4.88 \\
\hline $1-26$ & Silurian & $\mathrm{BKC}$ & 2.99 & 7.48 & 0.95 & 4.01 & 1.08 & 0.24 & 1.19 & 0.19 & 1.15 & 0.22 & 0.60 & 0.08 & 0.48 & 0.06 & 20.73 \\
\hline $1-27$ & Silurian & BKC & 2.07 & 5.09 & 0.67 & 2.76 & 0.53 & 0.13 & 0.56 & 0.08 & 0.42 & 0.07 & 0.22 & 0.03 & 0.15 & 0.02 & 12.78 \\
\hline $1-28 b$ & Silurian & $\mathrm{BKC}$ & 0.70 & 1.24 & 0.13 & 0.49 & 0.10 & 0.02 & 0.13 & 0.02 & 0.13 & 0.03 & 0.09 & 0.01 & 0.07 & 0.01 & 3.17 \\
\hline $1-31 d$ & Silurian & $\mathrm{BKC}$ & 9.35 & 26.81 & 3.53 & 13.19 & 2.43 & 0.34 & 1.75 & 0.21 & 1.03 & 0.19 & 0.53 & 0.06 & 0.40 & 0.05 & 59.87 \\
\hline $8-5 b$ & Silurian & $\mathrm{BKC}$ & 1.72 & 4.60 & 0.62 & 2.28 & 0.40 & 0.10 & 0.42 & 0.06 & 0.32 & 0.08 & 0.24 & 0.03 & 0.20 & 0.03 & 11.09 \\
\hline $8-13 d$ & Silurian & BKC & 14.53 & 32.22 & 3.47 & 10.91 & 1.60 & 0.21 & 1.18 & 0.12 & 0.53 & 0.09 & 0.24 & 0.03 & 0.20 & 0.03 & 65.36 \\
\hline $1-1 a$ & Devonian & RD1 & 0.13 & 0.25 & 0.03 & 0.14 & 0.03 & 0.01 & 0.03 & 0.00 & 0.02 & 0.00 & 0.01 & 0.00 & 0.01 & 0.00 & 0.69 \\
\hline $1-3-1 a$ & Devonian & RD1 & 0.23 & 0.42 & 0.06 & 0.18 & 0.05 & 0.01 & 0.04 & 0.01 & 0.04 & 0.01 & 0.02 & 0.00 & 0.03 & 0.00 & 1.10 \\
\hline $1-5 a$ & Devonian & RD1 & 0.13 & 0.18 & 0.02 & 0.09 & 0.02 & 0.00 & BDL & 0.00 & 0.03 & 0.01 & 0.03 & 0.00 & 0.02 & 0.00 & 0.54 \\
\hline
\end{tabular}


Table 6. Cont.

\begin{tabular}{|c|c|c|c|c|c|c|c|c|c|c|c|c|c|c|c|c|c|}
\hline Sample & Age & Type & $\begin{array}{c}\mathrm{La} \\
(\mathrm{ppm})\end{array}$ & $\begin{array}{c}\mathrm{Ce} \\
(\mathrm{ppm})\end{array}$ & $\begin{array}{c}\mathrm{Pr} \\
(\mathrm{ppm})\end{array}$ & $\begin{array}{c}\mathrm{Nd} \\
(\mathrm{ppm})\end{array}$ & $\begin{array}{c}\mathrm{Sm} \\
(\mathrm{ppm})\end{array}$ & $\begin{array}{c}\mathrm{Eu} \\
(\mathrm{ppm})\end{array}$ & $\underset{(\mathrm{ppm})}{\mathrm{Gd}}$ & $\begin{array}{c}\mathrm{Tb} \\
(\mathrm{ppm})\end{array}$ & $\begin{array}{c}\text { Dy } \\
(\mathrm{ppm})\end{array}$ & $\begin{array}{c}\text { Ho } \\
(\mathrm{ppm})\end{array}$ & $\begin{array}{c}\text { Er } \\
(\mathrm{ppm})\end{array}$ & $\begin{array}{c}\mathrm{Tm} \\
(\mathrm{ppm})\end{array}$ & $\begin{array}{c}\mathrm{Yb} \\
(\mathrm{ppm})\end{array}$ & $\begin{array}{c}\mathrm{Lu} \\
(\mathrm{ppm})\end{array}$ & $\begin{array}{l}\Sigma R E E \\
\text { (ppm) }\end{array}$ \\
\hline $1-5 b$ & Devonian & RD1 & 0.11 & 0.17 & 0.02 & 0.07 & 0.01 & 0.00 & BDL & BDL & 0.02 & 0.00 & 0.02 & 0.00 & 0.02 & 0.00 & 0.44 \\
\hline $1-7 a$ & Devonian & RD1 & 0.14 & 0.20 & 0.02 & 0.11 & 0.03 & 0.01 & BDL & 0.00 & 0.02 & 0.00 & 0.01 & 0.00 & 0.02 & 0.00 & 0.56 \\
\hline 8-1a & Devonian & RD1 & 0.31 & 0.53 & 0.07 & 0.24 & 0.04 & 0.01 & 0.04 & 0.01 & 0.05 & 0.01 & 0.02 & 0.00 & 0.02 & 0.00 & 1.35 \\
\hline $8-4 a$ & Devonian & RD1 & 0.76 & 0.94 & 0.15 & 0.61 & 0.17 & 0.03 & 0.18 & 0.03 & 0.16 & 0.04 & 0.12 & 0.01 & 0.07 & 0.01 & 3.29 \\
\hline $1-3-2 a$ & Devonian & $\mathrm{RD} 2$ & 0.25 & 0.45 & 0.06 & 0.23 & 0.04 & 0.01 & 0.04 & 0.01 & 0.05 & 0.01 & 0.03 & 0.00 & 0.02 & 0.01 & 1.22 \\
\hline $1-4 a$ & Devonian & RD2 & 0.33 & 0.40 & 0.05 & 0.15 & 0.03 & 0.01 & BDL & 0.00 & 0.03 & 0.00 & 0.01 & 0.00 & 0.02 & 0.00 & 1.05 \\
\hline $1-7 b$ & Devonian & RD2 & 0.14 & 0.20 & 0.03 & 0.10 & 0.03 & 0.00 & BDL & 0.01 & 0.02 & 0.01 & 0.01 & 0.00 & 0.01 & 0.00 & 0.56 \\
\hline $8-4 b$ & Devonian & RD2 & 0.89 & 1.09 & 0.18 & 0.72 & 0.16 & 0.03 & 0.22 & 0.03 & 0.19 & 0.04 & 0.14 & 0.02 & 0.09 & 0.01 & 3.80 \\
\hline $1-2 a$ & Devonian & RD3 & 0.43 & 0.66 & 0.08 & 0.29 & 0.06 & 0.01 & 0.07 & 0.01 & 0.04 & 0.01 & 0.02 & 0.00 & 0.02 & 0.00 & 1.72 \\
\hline $1-3-2 b$ & Devonian & RD3 & 0.42 & 0.76 & 0.11 & 0.42 & 0.12 & 0.02 & 0.08 & 0.01 & 0.08 & 0.02 & 0.05 & 0.01 & 0.04 & 0.01 & 2.15 \\
\hline $1-6 a$ & Devonian & RD3 & 0.20 & 0.23 & 0.03 & 0.13 & 0.03 & 0.00 & 0.03 & 0.00 & 0.03 & 0.01 & 0.02 & 0.00 & 0.01 & 0.00 & 0.73 \\
\hline $1-10 a$ & Devonian & RD3 & 1.67 & 1.53 & 0.20 & 0.70 & 0.13 & 0.03 & 0.14 & 0.02 & 0.14 & 0.03 & 0.10 & 0.01 & 0.06 & 0.01 & 4.78 \\
\hline $1-13 b$ & Devonian & RD3 & 6.74 & 6.77 & 1.32 & 5.40 & 1.07 & 0.25 & 1.25 & 0.16 & 0.96 & 0.20 & 0.56 & 0.06 & 0.38 & 0.05 & 25.17 \\
\hline $8-4 c$ & Devonian & RD3 & 0.91 & 1.12 & 0.18 & 0.75 & 0.16 & 0.04 & 0.23 & 0.03 & 0.21 & 0.05 & 0.12 & 0.02 & 0.11 & 0.01 & 3.94 \\
\hline $1-10 b$ & Devonian & $\mathrm{SXC}$ & 0.82 & 0.74 & 0.11 & 0.38 & 0.04 & 0.01 & 0.06 & 0.01 & 0.07 & 0.02 & 0.06 & 0.01 & 0.04 & 0.00 & 2.38 \\
\hline $1-11 a$ & Devonian & SXC & 1.13 & 1.16 & 0.16 & 0.64 & 0.09 & 0.02 & 0.14 & 0.02 & 0.12 & 0.02 & 0.07 & 0.01 & 0.05 & 0.01 & 3.63 \\
\hline $1-12 a$ & Devonian & SXC & 1.20 & 0.90 & 0.15 & 0.61 & 0.12 & 0.03 & 0.21 & 0.03 & 0.22 & 0.05 & 0.16 & 0.02 & 0.11 & 0.02 & 3.83 \\
\hline $1-13 a$ & Devonian & $\mathrm{DC}$ & 5.61 & 5.71 & 1.07 & 4.07 & 0.71 & 0.14 & 0.70 & 0.11 & 0.60 & 0.13 & 0.39 & 0.05 & 0.36 & 0.06 & 19.70 \\
\hline $8-1 b$ & Devonian & $\mathrm{BKC}$ & 0.88 & 1.22 & 0.14 & 0.48 & 0.07 & 0.01 & 0.07 & 0.01 & 0.06 & 0.02 & 0.04 & 0.01 & 0.05 & 0.01 & 3.08 \\
\hline
\end{tabular}



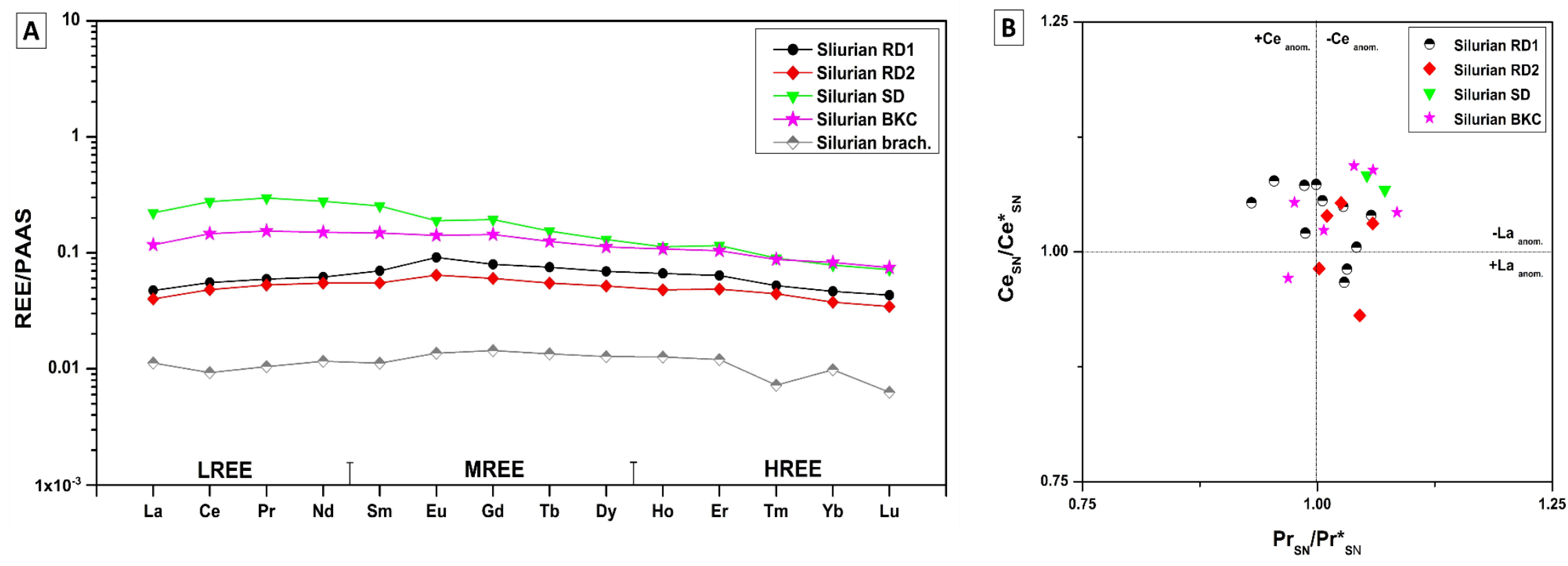

Figure 17. (A) Post-Archean Australian Shale (PAAS) normalized rare-earth element (REE) pattern for average values of fine (RD1) and medium (RD2) crystalline dolomite, saddle dolomite (SD) and fracture-filling calcite (BKC) samples, compared with average PAAS normalized REE pattern of well-preserved Silurian brachiopods [54]. (B) $\mathrm{Ce}\left(\mathrm{Ce} / \mathrm{Ce}^{*}\right)_{\mathrm{SN}}-\mathrm{La}\left(\operatorname{Pr} / \mathrm{Pr}{ }^{*}\right)_{\mathrm{SN}}$ anomaly crossplot of RD1, RD2, SD and BKC samples. 

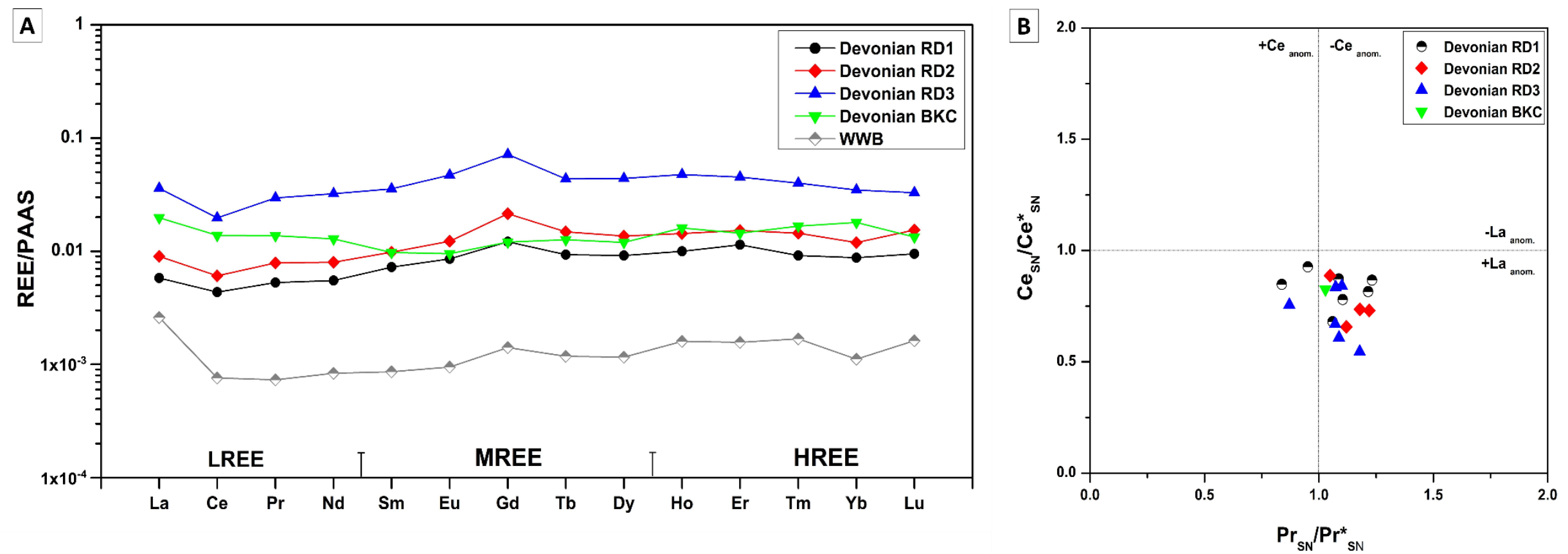

Figure 18. (A) PAAS normalized REE pattern for average values of fine (RD1) and medium (RD2) crystalline dolomite, dissolution seams dolomite (RD3) and fracture-filling calcite (BKC) samples, compared with average PAAS normalized REE pattern of modern warm water brachiopods [54]. (B) Ce (Ce/Ce*) ${ }_{\mathrm{SN}}-\mathrm{La}(\mathrm{Pr} / \mathrm{Pr})_{\mathrm{SN}}$ anomaly cross plot of RD1, RD2, RD3 and BKC samples. 
The average shale-normalized REEs concentrations in samples from Devonian formations present all the typical characteristic of seawater patterns including depletion of LREE over HREE (averages: RD1: $(\mathrm{La} / \mathrm{Yb})_{\mathrm{SN}}=0.66$; RD2: $(\mathrm{La} / \mathrm{Yb})_{\mathrm{SN}}=0.70 ; \mathrm{RD}$ : $\left.(\mathrm{La} / \mathrm{Yb})_{\mathrm{SN}}=1.03\right)$, enrichment of MREE (averages: RD1: $(\mathrm{Sm} / \mathrm{La})_{\mathrm{SN}}=1.25 ; \mathrm{RD} 2:(\mathrm{Sm} / \mathrm{La})_{\mathrm{SN}}=1.13 ; \mathrm{RD}$ : $\left.(\mathrm{Sm} / \mathrm{La})_{\mathrm{SN}}=1.0\right)$, negative Ce anomaly (Figure 18A,B), and slightly positive La and Gd anomalies (Figure 18A). Replacive dolomite RD1, RD2 and RD3 exhibit higher and progressively increasing average $\Sigma$ REE $(1.14 \pm 0.93 \mathrm{ppm}, 1.66 \pm 1.26 \mathrm{ppm}$ and $6.41 \pm 8.50 \mathrm{ppm}$, respectively) compared with the average of modern warm water brachiopods $(0.25 \pm 0.2 \mathrm{ppm})$ proposed by Azmy et al. [55]. Slightly different patterns, which are still comparable to the trend of modern warm water brachiopods, characterize REEs of BKC with $\Sigma$ REE of $3.08 \mathrm{ppm}$ which falls between those of RD1 and RD3 (Figure 18A).

\section{Discussion and Interpretations}

The petrographic and geochemical results obtained in this study indicate that diagenesis of the Silurian and Devonian dolomitized successions have been subjected to fluids of variable origins and compositions, as described below.

\subsection{Constraints from Petrography}

\subsubsection{Silurian}

The diagenetic history of the Silurian formations includes dolomitization, mechanical and chemical compaction, fracturing, dissolution, silicification and calcite and evaporite cementation (Figure 19). The diagenetic processes above listed are described in depth in Tortola [46], on which this paper is largely based.

\begin{tabular}{|l|l|l|}
\hline Dime & Late & Burial \\
\hline Isopachous calcite (ISC) \\
Syntaxial calcite (SXC) \\
Silicification \\
Fracturing I \\
Drusy calcite (DC) \\
Fine Crystalline dolomite (RD1) \\
Medium-coarse Crystalline dolomite (RD2) \\
Dissolution seams \\
Stylolitization \\
Selective replacive dolomite (RD3) \\
Fracturing II and III \\
Dissolution
\end{tabular}

Figure 19. Paragenesis of Silurian formations (modified from Tortola [46]).

\section{Dolomitization}

Replacive dolomite crystal size is often influenced by the texture of the precursor limestone [55]. Hence, fine-crystalline dolomite may represent the replacement of fine-grained limestone, whereas coarser replacive dolomite may either represent replacement of coarse-grained limestone or recrystallization of precursor dolomite matrix [55].

RD1 is commonly characterized by closely packed unimodal mosaics of micro to fine-crystalline dolomite which preserved the finely laminated texture of the precursor mudstone. The characteristics showed by RD1, are comparable to fine crystalline dolomite observed in Silurian formations from different areas of southwestern Ontario [5,7,8,56]. This dolomite has been interpreted to be formed from evaporative reflux of hypersaline brines in a sabkha-like setting in a near-surface or shallow burial setting, in the condition of relatively high salinity and low temperature $[47,57,58]$. This interpretation is also supported by a cross-cutting relationship with chemical compactional features, such as dissolution 
seams and stylolites, which evidently postdated RD1. However, there is no evidence of supratidal lithofacies and abundant evaporites.

As mentioned by Zheng [7], the relatively coarser size of replacive fine crystalline dolomite (20-50 $\mu \mathrm{m})$ compared to modern dolomites $(<4 \mu \mathrm{m})$ can be explained by an increase of crystal size due to early recrystallization. This early recrystallization is possibly supported by the negative shift in oxygen isotopic composition discussed in the next section. Cathodoluminescence of mainly dull to dark red luminescence for RD1 suggests replacement in a reducing environment at shallow burial conditions [59].

Medium replacive dolomite (RD2) shows slightly coarser crystal size but similar texture compared to RD1. Dolomite crystal coarsening can occur in different scenarios: (1) slow precipitation rate [60]; (2) increase of temperature due to progressive increasing burial conditions [47]; (3) recrystallization of precursor dolomite or overgrowth of later stage dolomite on existent cores of earlier dolomite [47,61-64].

Many studies (e.g., $[62,64,65])$ suggest that non-planar crystal boundaries, coarsening of crystal size and absence of zonation under CL can represent evidence of recrystallization. According to Machel [66], the most accredited definition of recrystallization is the one proposed by the Glossary of Geology [67], which states that recrystallization of a mineral determines the formation of a new mineral commonly characterized by coarser crystals and with either same or different composition. The coarsening of crystal size coupled with the lack of zonation under CL observed in RD2 may indicate recrystallization $[64,68,69]$. The occurrence of strictly non-planar crystal boundaries was not observed in RD2 from both Silurian and Devonian samples, possibly because early dolomite, formed from seawater can preserve unchanged geochemistry and texture after a certain depth of burial and several million years [70].

According to Machel [66], dolomite can be defined "significantly recrystallized" if it is characterized by the variation of at least one of the following parameters: (1) increase of crystal size or in non-planar crystal boundaries; (2) progressive ordering; (3) change in composition including stable and radiogenic isotopes, stoichiometry, trace and rare earth elements, fluid inclusions and zonation; (4) change in paleomagnetic properties.

The increase of crystal size, the negative shift of $\delta^{18} \mathrm{O}$ from postulated values of marine dolomite formed during Silurian and changes in trace and rare earth elements (discussed in the next sections), make RD2 "significantly recrystallized", but also "insignificantly recrystallized" with respect to the increase of non-planar crystal boundaries and progressive ordering $[1,5,66]$. Crystal coarsening of fabric-destructive pervasive replacive medium (50-100 $\mu \mathrm{m})$ crystalline dolomite (RD2) may suggest recrystallization from the precursor dolomite RD1, but the presence of cloudy, non-ferroan cores and clear, ferroan rims as a common characteristic of RD2 crystals (Figure 4F) may also suggest overgrowth on earlier dolomite [47]. Under CL, medium dolomite RD2 shows slightly more red luminescence compared to RD1, which indicates that its formation took place in slightly deeper burial conditions in a more reduced environment [59]. As the hypothesis of overgrowth of RD2 on early dolomite is not quite confirmed by CL observation, no brighter luminescent zones have been observed in correspondence of the clear rims, the interpretation of recrystallization seems more likely. Selective replacive medium crystalline dolomite (RD3) occurred in association with dissolution seams during early chemical compaction. Similar textures of patchy dolomite formed in association with chemical compactional features have been previously described (e.g., [71,72]) as dolomite formed from marine or connate waters flowed through dissolution seams which are believed to have behaved as preferential transport path for the dolomitizing fluids. Alternatively, the magnesium required for the formation of RD3 may be supplied by the remobilization of the $\mathrm{Mg}$ released in solution from the dissolution of high magnesium calcite [72,73]. The association with dissolution seams suggests that RD3 formed in shallow to intermediate burial realm postdating RD1 and RD2. The common presence of dark cores and clear rims as distinctive characteristics of RD3 crystals (Figure 4C) may also suggest overgrowth on the previous dolomite phases [47]. This evidence, as mentioned for RD2, is not confirmed by 
cathodoluminescence which shows luminescence comparable with those of RD2 without any zonation or difference in terms of luminescence between cores and rims in RD3 crystals (Figure 4D).

The less abundant saddle dolomite (SD) is observed as fracture and vug-filling cement occluding second and third generation of fracture, postdating RD1, RD2 and RD3 and predating blocky calcite (BKC) and evaporite cement (GY and ANH) (Figure 4E,G-I). This petrographic evidence suggests that saddle dolomite formed during a late diagenetic event possibly in intermediate burial conditions.

\section{Calcite Cementation}

Calcite cementation represents an important diagenetic process that affected Silurian carbonate rocks in the Michigan Basin. It started in the early-stage, during marine environmental conditions, to continue during progressively deeper burial.

Isopachous calcite (ISC) was only observed in Silurian formations as cement characterized by bladed crystals surrounding coated grains (Figure 6A) formed prior to mechanical compaction and consequently prior to SXC, DC and BKC. It is interpreted to have formed from seawater immediately after deposition in a near-surface marine environment, inhibiting and hence predating mechanical compaction. Under CL this cement is dull-red (Figure 4D), occasionally non-luminescent, indicating precipitation in a slightly reducing environment where $\mathrm{Fe}^{2+}$ and $\mathrm{Mn}^{2+}$ were available to be incorporated in the crystal lattice [59].

Syntaxial overgrowth calcite (SXC) is mainly cloudy and inclusion-rich, evidence of precipitation in near-surface marine, meteoric or mixing-zone environments [74]. The presence of dissolution seams deflecting around and cross-cutting SXC indicates that its precipitation took place before chemical compaction. Under CL this cement is red to bright red indicating precipitation in a redox environment where $\mathrm{Fe}^{2+}$ and $\mathrm{Mn}^{2+}$ were available to be incorporated in the crystal lattice [59]. Isotopic values for this cement from both Silurian and Devonian rocks (Figure 11) show overlapping and/or slightly depleted values relative to the postulated ratios for their respective ages; hence evidence for their formation form seawater parentage fluids.

Drusy mosaic calcite (DC), was mainly observed as vug, mould and fracture-filling cement (Figure 6C), which can form in near-surface meteoric as well as in burial environment [75,76] but its formation is not commonly related to the marine environment [62]. Under CL it mainly shows dull-red luminescence (Figure 6D), evidence of precipitation in a reducing condition [59]. Paragenetically, DC postdate silica and predated dissolution seams and stylolites (Figure 5A) as well as late blocky calcite cement (Figure 5B). Hence, its formation represents a relatively early diagenetic event predating chemical compaction.

Late diagenetic blocky calcite cement $(B K C)$ is characterized by coarse crystals $(>500 \mu \mathrm{m})$ and it is mainly observed as vug and fracture filling cement which possibly formed in a burial environment (e.g., [77]). Petrographically, BKC shows dull to bright orange zoned luminescence under CL indicating formation in a progressively reducing environment. Based on petrographic evidence, BKC is interpreted to be the latest phase of calcite cementation, postdating saddle dolomite cement (SD) (Figure 4I) and predating evaporite cementation.

\subsubsection{Devonian}

The diagenetic history of Devonian successions includes dolomitization mechanical and chemical compaction, fracturing, dissolution, silicification, and calcite cementation (Figure 20). These sequences are based on petrographic cross-cutting relationships supplemented by geochemical evidence. 


\begin{tabular}{|l|l|l|}
\hline \multicolumn{1}{|c|}{ Time } & Larly \\
\hline Diagenetic event/phase & Marine & Burial \\
\hline Micritization & Syntaxial calcite (SXC) \\
Dog-tooth calcite (DTC) \\
Silicification \\
Drusy calcite (DC) \\
Fine Crystalline dolomite (RD1) \\
Medium-coarse Crystalline dolomite (RD2) \\
Dissolution seams \\
Stylolitization \\
Selective replacive dolomite (RD3) \\
Fracturing I and II \\
Dissolution \\
Blocky calcite (BKC)
\end{tabular}

Figure 20. Paragenesis of Devonian Formations (modified from Tortola [46]).

Dolomitization

Devonian replacive dolomites RD1, RD2 and RD3 (Figure 7) show similar characteristics in terms of timing and environments compared to the respective dolomite phases observed in the Silurian formations.

RD1 is commonly characterized by closely packed unimodal mosaics of micro to fine-crystalline dolomite (Figure 7A) which preserved the original texture of the precursor mudstone. Fine-crystalline dolomites distinguished in Devonian formations in previous studies (e.g., $[2,5,33,56])$ show similar texture if compared to RD1 and are interpreted to be formed from evaporative reflux of hypersaline brines in a sabkha-like setting. Hence, the mimetic pervasive replacive micro to fine crystalline dolomite (RD1) is possibly formed in a low temperature, near-surface or shallow burial environment. However, there is no evidence of abundant evaporites commonly associated with this model. Slightly coarser size of RD1 crystals, in comparison with recent dolomites, suggest early recrystallization [7], which is supported by oxygen isotopic composition discussed in Section 5.2. Cathodoluminescence characteristics of RD1 showing mainly dull to dark red luminescence (Figure 7B) suggest replacement in a shallow reducing environment [53]. Cross-cutting relationship with dissolution seams and stylolites suggests that RD1 formed prior to chemical compaction.

Crystal coarsening of fabric-destructive pervasive replacive medium crystalline dolomite (RD2) (Figure 7C,D) suggests possible recrystallization of the precursor dolomite RD1 [47,61-64]. The lack of zonation under CL coupled with the coarsening of crystal size observed in RD2 may represent additional evidence of recrystallization $[64,68]$. Devonian medium replacive dolomite shows slightly brighter red luminescence compared to RD1 (Figure 7B), possible evidence of a slightly deeper burial formation in a more reducing environment.

Selective replacive medium crystalline dolomite (RD3) has similar characteristics to RD3 observed in Silurian formations. It is commonly associated with dissolution seams and stylolites, which act as preferential paths for dolomitizing fluids [72]. Hence, it is interpreted to have formed in a shallow to intermediate burial regime postdating RD1 and RD2 (Figure 7E,F) and alongside with chemical compaction. The common presence of dark cores and clear rims as distinctive characteristics of RD3 crystals (Figure 7E) may also indicate overgrowth on the previous dolomite phases [47]. This hypothesis is not confirmed by cathodoluminescence results which shows luminescence slightly brighter with those of RD2 but without any zonation or difference in terms of luminescence between cores and rims within the crystals (Figure 7B,F).

\section{Calcite Cementation}

Calcite cementation represents an important process within the paragenesis of Devonian carbonate rocks in the Michigan Basin (Figure 9). It started in the early-stage, during marine environmental conditions, to proceed during progressively deeper burial stages. 
Syntaxial overgrowth calcite cement (SXC) is commonly observed in bioclastic grainstone, usually as nucleation over echinoderm plates or crinoid ossicles that act as single crystals (Figure 9A). Syntaxial overgrowth is mainly cloudy and inclusion-rich, evidence of precipitation in near-surface marine, meteoric or mixing-zone environments [74]. The presence of dissolution seams deflecting around and crosscutting SXC indicates that its precipitation took place before chemical compaction. Under CL this cement is dull-red indicating precipitation in a reducing environment where $\mathrm{Fe}^{2+}$ and $\mathrm{Mn}^{2+}$ were available to be incorporated in the crystal lattice [59].

Dogtooth calcite cement (DTC), which is only present in bioclastic grainstones from Devonian formations (Figure 9B), can form in different environments. According to Reinhold [78] this cement can form: (1) in a marine-phreatic environment when dogtooth calcite occurs in intraskeletal voids; (2) in shallow burial environment when observed in stromatactis cavities succeeding radiaxial fibrous calcite cement. DTC is observed growing normally to the substrate (mainly in intraskeletal pores) with sharply pointed acute crystals. It formed early within the diagenetic history of the Devonian formations, in a near-surface or shallow burial environment, predating the formation of silica and consequently predating RD1. The presence of zoned dull to red luminescence under CL indicates possible formation in a progressively reducing environment [53]. As sampling of a pure specimen for geochemical analyses was not possible, the conclusion concerning time and environment of DTC's occurrence are based exclusively on petrographic observations.

Drusy mosaic calcite (DC), mainly observed as vug, mould and fracture-filling cement (Figure 9D,E), can form in near-surface meteoric as well as in burial environment $[75,76]$. Its formation is not commonly related to the marine environment [71]. CL observations reveal luminescent zones ranging from non- to orange bright luminescent (Figure 9C) indicating fluctuation from well oxidizing environment, which inhibited the incorporation of $\mathrm{Fe}^{2+}$ and $\mathrm{Mn}^{2+}$, to a slightly more reducing condition, respectively [59]. DC postdated silica and predated dissolution seams, stylolites and late blocky calcite cement (Figure 9E). Hence, its formation is thought to represent a relatively early diagenetic event which possibly took place in a shallow burial environment, predating chemical compaction.

Late diagenetic blocky calcite cement (BKC) possibly formed in the burial environment. BKC shows dull to bright zoned luminescence under CL (Figure 9F) indicating formation in a progressively reducing environment. Based on petrographic evidence, BKC is interpreted to be the latest phase of calcite cementation (Figure 20) postdating fractures.

\subsection{Constraints from Stable O, C and Radiogenic Sr Isotopes}

The conditions of precipitation and/or recrystallization of diagenetic minerals can be predicted using their oxygen isotopic composition, which is a function of the temperature as well as the $\delta^{18} \mathrm{O}$ composition of the diagenetic fluids involved [50]. The recrystallization of dolomite, and associated chemical and textural changes, is considered a frequent process in carbonates associated with increasing burial depth $[50,64,66,69,79]$. Isotopic data show a general overlap between $\delta^{18} \mathrm{O}$ and $\delta^{13} \mathrm{C}$ values of replacive dolomites (RD2 and RD3) from Silurian and Devonian successions (Figure 10). In both age groups, for these dolomite samples display similar $\delta^{13} \mathrm{C}$ compared to those of carbonates formed in equilibrium with seawater of the respective age (for Silurian: 0.5 to 2.5\% VPDB [80]; and for Middle Devonian: 0.5 to $2.5 \%$ o VPDB [49]) (Figure 10). The $\delta^{13} \mathrm{C}$ values possibly reflect the carbon isotopic composition of the precursor limestones (e.g., [81]). However, many $\delta^{13} \mathrm{C}$ values in Silurian RD1 departed from the postulated values for Silurian carbonates. In contrast, in both age groups, the $\delta^{18} \mathrm{O}$ isotopic composition shows a negative shift from the postulated values for their respective age.

\subsubsection{Silurian}

Dolomite formed in equilibrium with seawater should display $\delta^{18} \mathrm{O}$ isotopic composition enriched of about $3 \pm 1 \%$ o (e.g., [82]). Calcitic matrix is characterized by $\delta^{18} \mathrm{O}$ values varying from -8.16 to $-4.73 \%$ o VPDB and hence with some exceptions, mostly falling into the range of the postulated values for Silurian marine calcite ( -3 to $-5.5 \%$ o VPDB [80]). Assuming that the Silurian seawater with 
an isotopic composition of $-3.5 \%$ o SMOW [83] represents the source of dolomitizing fluids for the formation of RD1, its range of $\delta^{18} \mathrm{O}$ values should vary from -0.25 to $-2.5 \%$ o VPDB. The calculated average value (-1.4\% VPDB) would correspond to an estimated value of $24{ }^{\circ} \mathrm{C}$ employing the fractionation equation proposed by Land [82]. However, values obtained from RD1 show a negative shift of about $2-6 \%$ o from the $\delta^{18} \mathrm{O}$ average value $(-1.4 \%$ o VPDB) expected for the Silurian dolomite (Figure 10). RD2, RD3 and SD exhibit a negative shift of about $2-8 \%$ o compared with the $\delta^{18} \mathrm{O}$ average value of the Silurian marine dolomite (Figure 10). An explanation to justify this negative shift of $\delta^{18} \mathrm{O}$ values can be the interaction with meteoric water or formation in the burial regime at relatively high temperatures (e.g., [69]). The interaction with meteoric water should be demonstrated by evidence of subaerial exposure such as karst phenomena, presence of vadose cement or other features associated with meteoric diagenesis. Although previous studies underline the presence of an erosional unconformities (between Cabot Head and the overlying Fossil Hill formations and between Bass Island and Bois Blanc formations [34]), the lack of evidence of karstification in the studied samples (e.g., [69]), make the meteoric diagenesis an improbable scenario for matrix dolomites. Hence, the hypothesis of recrystallization with burial seems to be more likely.

$\mathrm{RD} 1$ shows negative $\delta^{13} \mathrm{C}$ values, possibly related to the formation of this dolomite in a shallow burial environment associated with bacterial sulphate reduction (BSR) [84]. This hypothesis is supported by the presence of minute framboidal pyrite crystals (Figure 4A) embedded within RD1 [85].

Even though, there is no evidence of the corresponding variation in terms of crystal size coarsening and depletion of $\delta^{18} \mathrm{O}$ values (e.g., [8]) comparing data from RD1 and coarser dolomites (RD2 and RD3), the negative shift of $\delta^{18} \mathrm{O}$ values could be associated to recrystallization and/or to interaction with hydrothermal fluids at relatively high temperature (e.g., $[5,69,77,86,87])$.

Most of the dolomite samples (both, matrix and cement) from Silurian formations are characterized by ${ }^{87} \mathrm{Sr} /{ }^{86} \mathrm{Sr}$ ratios falling in the range of postulated values for Silurian seawater $(0.7078-0.7087$ [52,53]) (Figure 12). However, some samples show slightly more radiogenic values than those of coeval seawater. This variation from the postulated values can be related to the recrystallization of early dolomite and to water/rock interaction with feldspar-bearing rocks [5]. In an overall view, the ${ }^{87} \mathrm{Sr} /{ }^{86} \mathrm{Sr}$ ratios for dolomite matrix (RD1, RD2 and RD3), dolomite cement (SD) and late-stage calcite cement (BKC) suggest for both a seawater-dominated parental fluid.

Most of the calcitic samples show $\delta^{13} \mathrm{C}$ values, in range with postulated values for Silurian marine calcite with the exception for late blocky calcite which clearly shows a negative shift from the equilibrium values (Figure 11). This may suggest a separate input of oxidized organic carbon possibly related to interaction with hydrocarbons (e.g., [77]).

\subsubsection{Devonian}

Calcitic matrix is characterized by $\delta^{18} \mathrm{O}$ values varying from -8.16 to $-4.73 \%$ o VPD and hence with some exceptions (Figure 11), mostly falling into the range of the postulated values for Devonian marine calcite ( -4 to $-6 \%$ VPDB [49]). Most of the calcitic samples show $\delta^{13} \mathrm{C}$ values, in range with postulated values for Devonian marine calcite with the exception for late BKC which clearly shows a negative shift from the equilibrium values (Figure 11). This, as already mentioned for Silurian BKC, may suggest a separate input of oxidized organic carbon possibly related to interaction with hydrocarbons (e.g., [77]).

Considering that dolomite formed in equilibrium with seawater, it should display $\delta^{18} \mathrm{O}$ isotopic composition enriched of about $3 \pm 1 \%$ o (e.g., [82]), and assuming that Devonian seawater, with an isotopic composition of $-2 \%$ o SMOW [51,88], represents the source of dolomitizing fluids for the formation of RD1, its range of $\delta^{18} \mathrm{O}$ values should vary from -1 to $-3 \%$ o VPDB. The calculated average value $\left(-2 \%\right.$ o VPDB) would correspond to an estimated value of $33^{\circ} \mathrm{C}$ employing the fractionation equation proposed by Land [82]. However, RD1 shows a negative shift of about $1-5 \%$ o from the average value (-2\% VPDB) of $\delta^{18} \mathrm{O}$ expected for Devonian dolomite (Figure 10). RD2 and RD3 also 
exhibit a similar negative shift compared with the $\delta^{18} \mathrm{O}$ average value of Devonian marine dolomite (Figure 10).

This negative shift of $\delta^{18} \mathrm{O}$ values can be also related to the interaction with meteoric water or formation in burial regime at relatively high temperatures (e.g., [69]). As already mentioned in the previous section, the interaction with meteoric water should be demonstrated by evidence of subaerial exposure such as karst features, such as the presence of vadose cement or other evidence associated with meteoric diagenesis. Although there is no evidence of karstification in the samples collected and analyzed in this study, a previous study [89] demonstrated the presence of dissolution processes mostly active in the shallow subsurface, usually $<200 \mathrm{~m}$ depth in south-western Ontario. At the local scale, approximately $180 \mathrm{~m}$ of Devonian bedrock beneath the Bruce nuclear site are karstic with karstification and higher-permeability confined intervals also found within the Salina A1 dolostone and the Guelph Formation [89]. Hence, the possibility of meteoric water influence cannot be discounted completely.

However, the absence of a negative shift of $\delta^{13} \mathrm{C}$ values, commonly associated with the meteoric diagenesis (e.g., [69]), coupled with the marked $\delta^{18} \mathrm{O}$ isotopic negative values for matrix dolomite may favour the hypothesis of recrystallization.

The majority of the dolomite matrix, as well as the late calcite (BKC) from Devonian formations, are characterized by ${ }^{87} \mathrm{Sr} /{ }^{86} \mathrm{Sr}$ ratios falling in the range of postulated values for Devonian seawater (0.7078-0.7080 [51]) (Figure 12). However, one sample shows more radiogenic isotopic composition than those of coeval seawater. This variation from the postulated values, even if isolated, can be related to the recrystallization of early dolomite and to water/rock interaction with the overlying Upper Devonian sandstones and shales [56]. Hence, the results ${ }^{87} \mathrm{Sr} /{ }^{86} \mathrm{Sr}$ ratios for dolomite matrix (RD1, RD2 and RD3), and late-stage calcite cement (BKC) suggest for both seawater-dominated parental fluids.

\subsection{Constraints from Fluid Inclusions}

As shown in Figure 15 Silurian replacive dolomite (RD2) is characterized by slightly higher homogenization temperature $\left(89.1^{\circ} \mathrm{C}\right)$ compared to those hosted in Devonian RD2 $\left(83.2^{\circ} \mathrm{C}\right)$. These values are in both cases lower than $\mathrm{T}_{\mathrm{h}}$ values given by Barnes et al. [90] (Th: $155{ }^{\circ} \mathrm{C}$ ) for the central part of the Michigan Basin, but comparable $\mathrm{T}_{\mathrm{h}}$ values and salinity with those reported by Haeri-Ardakani et al. [5] ( $\mathrm{T}_{\mathrm{h}}: 104{ }^{\circ} \mathrm{C} ; 20.3 \mathrm{wt} . \% \mathrm{NaCl}$ eq.) for different areas of southwestern Ontario. Fluid inclusions hosted in saddle dolomite in Silurian formation also show slightly higher values of $\mathrm{T}_{h}$ and salinity ( $\mathrm{T}_{\mathrm{h}}: 124{ }^{\circ} \mathrm{C} ; 28.5 \mathrm{wt} . \% \mathrm{NaCl}$ eq.) compared to matrix dolomite and to saddle dolomite fluid inclusions analyzed in the study carried out by Haeri-Ardakani et al. [5] $\left(\mathrm{T}_{\mathrm{h}}: 108^{\circ} \mathrm{C} ; 25.5 \mathrm{wt} . \%\right.$ $\mathrm{NaCl}$ eq.).

Late calcite cement $(B K C)$ fluid inclusions results show significantly higher $T_{h}$ values but lower salinity for the Devonian samples compared to those hosted in the Silurian calcite. Fluid inclusions hosted in BKC of the Devonian formation show $T_{h}$ values significantly higher and lower salinity if compared with values obtained in the central part of the Michigan Basin by Luczaj et al. [13] $\left(\mathrm{T}_{\mathrm{h}}\right.$ : $140{ }^{\circ} \mathrm{C} ; 29.2 \mathrm{wt} . \% \mathrm{NaCl}$ eq.), whereas it shows similar salinity and higher $\mathrm{T}_{\mathrm{h}}$ if compared with the values proposed by Haeri-Ardakani et al. [5] ( $\mathrm{T}_{\mathrm{h}}: 126^{\circ} \mathrm{C} ; 19.7 \mathrm{wt} . \% \mathrm{NaCl}$ eq.).

These results coupled with the negative shift of $\delta^{18} \mathrm{O}$ values may suggest, in both age groups, the formation of RD2 was at relatively high temperatures from saline brines (e.g., [77]). Similar ranges of homogenization temperatures characterize blocky calcite cement and saddle dolomite, in the Silurian formations, and may represent evidence of similarity in terms of mineralizing fluid responsible for their formation. This assumption is also supported by evidence from REE analysis (discussed in the following section). The overall higher salinity (Figures 15B and 16B) which characterizes RD2 and BKC from Silurian formations compared to those of the same mineral phases from Devonian formations, suggests that the diagenetic fluids responsible for their formation were saline basinal brines resulted from the dissolution of evaporites hosted in Silurian formations (e.g., [5,77]). The high homogenization temperatures of late calcite cement and saddle dolomite and the relatively high $\mathrm{T}_{\mathrm{h}}$ of fluid inclusions hosted in replacive dolomite (Figures $14 \mathrm{~A}$ and $15 \mathrm{~A}$ ) are significantly higher than the maximum burial 
temperatures suggested for the study area (ca $60-90{ }^{\circ} \mathrm{C}$ [91]) for both age groups and hence, it may suggest the involvement of hydrothermal fluids $[5,13,90]$.

The distinct patterns of salinity and homogenization temperature (Figures 14-16) that characterize Devonian and Silurian dolomite may suggest that dolomitization/dolomite alteration and other related diagenetic processes are the result of two different diagenetic fluid systems: (1) a diagenetic fluid system that affected Silurian carbonates characterized by high temperatures and high salinity and (2) a diagenetic fluid system that affected Devonian carbonates characterized by slightly lower temperatures and salinity (e.g., [77]).

\subsection{Constraints from Geochemistry}

\subsubsection{Stoichiometry}

Most dolomite samples, with some exceptions for RD1, show Ca-rich, non-stoichiometric composition in both Silurian and Devonian formation. Several studies on dolomite $[50,68,79,92,93]$ suggested that the recrystallization of fine crystalline dolomite forms coarser, more stable and more stoichiometric dolomite. However, coarser pervasive dolomites are overall less stoichiometric than fine crystalline dolomite. A possible explanation for such a trend is that these results reflect the average composition of the cores and rims of the crystals. Separate measurements for cores and rims, which were not performed for these dolomites, may have shown very substantial stoichiometric differences. The model proposed by Sibley [92] suggests that progressive recrystallization of non-stoichiometric dolomite should result in an increasingly stoichiometric dolomite characterized by Ca-rich cores and stoichiometric rims. Even though, this phenomenon has been observed and documented in many studies (e.g., [72,94]), stoichiometry has not been achieved in the Silurian and Devonian formations investigated. An experimental study by Malone et al. [95], demonstrated that dolomite subjected to temperatures of $50{ }^{\circ} \mathrm{C}-200{ }^{\circ} \mathrm{C}$ lead to its recrystallization with a rapid increase of stoichiometry in the first part of the experiment, but with a slowing down as reactions progressed. Despite complete recrystallization at $200^{\circ} \mathrm{C}$, dolomite stoichiometry was not achieved.

The interpretation that better explains this trend is that earlier-formed dolomite has been recrystallized by later, Ca-rich, and warmer basinal fluids, under conditions that did not allow these dolomites to achieve stoichiometry (e.g., [69]).

\subsubsection{Trace Elements: Iron, Manganese and Strontium}

The distribution of iron and manganese in solution is strictly controlled by redox conditions (Eh) [96] as well as their concentrations in precursor limestone and precipitation rate [97]. In the condition of positive Eh (oxidizing conditions), $\mathrm{Fe}^{2+}$ and $\mathrm{Mn}^{2+}$ oxidize passing from a divalent to a trivalent state inhibiting their incorporation in carbonates crystal lattice [59].

RD1, RD2 and SD in Silurian formations and RD1, RD2 and RD3 in Devonian formations show a progressive increase in Fe and Mn concentration (Table 5). Previous studies on dolomite [65,98] suggested that the relative enrichment of Fe and $\mathrm{Mn}$ in later dolomites can be attributed to dolomite recrystallization. Higher content of Fe and $\mathrm{Mn}$ in coarser dolomites could be related to either formation under relatively more reducing conditions [99] or increasing Fe and Mn distribution coefficients resulting from higher temperatures or slower precipitation rate [100]. Despite this increase of Fe and $\mathrm{Mn}$ there is no evidence of a corresponding variation in terms of Sr concentration between RD1 and younger dolomite phases in both Silurian and Devonian formations. This evidence may suggest that the different phases of dolomite observed within both age groups are perhaps linked to their parental mineralizing fluids (in this case seawater-dominated fluids). The low Sr concentrations (mostly in the range between 50 and $100 \mathrm{ppm}$ for all dolomite samples in both age groups) are comparable to those of ancient dolomite precipitated from marine waters (e.g., 40-150 ppm [101]), but significantly lower than modern protodolomites (500-700 ppm) formed in evaporitic marine settings [79,102]. Decrease of Sr concentration with increasing crystal size is interpreted to be associated with dolomite recrystallization 
in presence of Sr-depleted meteoric waters (e.g., [50,79,98,103]. However, matrix dolomites from both age groups do not show evidence of a decrease of Sr concentrations with increasing crystal size.

Despite, the lack of evidence of co-variation of Sr with either Fe and Mn, their higher concentrations in coarser dolomite (RD2 and SD in Silurian samples and RD2 and RD3 in Devonian samples) compared to RD1, can be related to their formation from Fe- and Mn-enriched fluids under more reducing conditions [7].

\subsubsection{Rare Earth Elements (REE)}

Previous studies focused on REE compositions of carbonate rocks suggest controversial scenarios in terms of preservation [104,105] or modification [54], after diagenesis, of rare earth element patterns and concentrations compared with those of their precursor seawater. Concentrations of REE in ancient carbonate rocks can be useful tools to establish the nature of the mineralizing source [106-108]. Chaudhuri and Cullers [109], Webb et al. [104] and Allwood et al. [105] suggested that during the post-depositional processes such as diagenesis and metamorphism REEs patterns can remain essentially unaffected, considering that a large amount of diagenetic fluids is required to record substantial changes [106]. In other words, the REE concentrations in carbonate rocks are principally influenced by the depositional environment $[110,111]$. However, according to recent studies (e.g., [5,54]) diagenetic processes may sensibly alter REEs patterns and concentrations, making them an ideal tool for the understanding of REEs relocation in carbonate rocks.

The distinctive Post-Archean Australian Shales (PAAS) normalized seawater REE concentrations have patterns characterized by the following features: depletion of light REE, negative Ce anomaly and slight positive La and Gd anomalies [43,112-114].

Silurian

Average shale-normalized REE patterns of RD1 and RD2 show similar trends compared to those of Silurian brachiopods [54] but with significantly higher $\Sigma$ REE (Figure 17A). All dolomite and calcite samples are characterized by a slight enrichment of LREE over HREE and a more significant enrichment of MREE. The comparison between the trend of Silurian brachiopods [54] and those of RD1 and RD2 (Figure 17A), possibly suggests an initial common seawater-dominated source of diagenetic fluids partially masked afterward by a different evolution of the diagenetic fluids [5]. Differently from Devonian patterns, Silurian dolomite trends are, in fact, characterized by a minor negative La anomaly and both cases of positive and negative Ce anomalies (Figure 17A,B) possibly implying their formation from evolved seawater. Both types of dolomite RD1and RD2 exhibit higher average $\Sigma$ REE $(11.07 \pm 0.93 \mathrm{ppm}$, and $9.793 \pm 7.8 \mathrm{ppm}$, respectively) compared with the average of Silurian brachiopods (2.21 ppm) proposed by Azmy et al. [54].

Saddle dolomite (SD) and Blocky calcite cement (BKC) show similar REE shale-normalized trends (Figure 17A) with average $\Sigma$ REE ( $47.06 \pm 41.95 \mathrm{ppm}$ and $23.74 \pm 23.00 \mathrm{ppm}$, respectively) and both significantly differ from the Silurian Brachiopods REE patterns. SD and BKC both show major negative La and Ce (Figure 17B) anomalies as well as a slight negative Eu anomaly (Figure 17A). The differences between replacive dolomite matrix RD1 and RD2 compared with Saddle dolomite and blocky calcite cement include progressively higher $\Sigma$ REE and a more pronounced enrichment in LREE, and hence may suggest a different source of REEs (Figure 17).

\section{Devonian}

Average shale-normalized REE patterns and their comparison with those of modern warm water brachiopods [54] show that all dolomite types and late calcite cement sampled from Devonian formations have maintained the original seawater REE characteristics with a negative Ce anomaly (Figure 18A,B), and slightly positive La and Gd anomalies [43,112-114]. Proceeding from older (RD1) to younger (RD3) dolomite, shale-normalized REE show similar patterns coupled with a progressive enrichment in average $\Sigma$ REE (Figure 18). These characteristics may indicate a common 
seawater-dominated diagenetic fluid slightly modified during progressive deeper burial because of the increasing water/rock interaction [5].

\subsection{Evolution of Diagenetic Fluids}

The evolution of diagenetic fluids involved during dolomitization in the eastern side of the Michigan Basin can be deduced by integrating petrographic, isotopic and fluid inclusions data.

The relationships between the oxygen isotopic composition of the mineral phase, of the fluid $\left(\delta^{18} \mathrm{O}_{\text {fluid }}\right)$ and temperature of formation ( $\mathrm{T}_{\mathrm{h}}$ from fluid inclusions studies) are shown in Figure 21.

Figure 21A shows the relationship between the measured $\delta^{18} \mathrm{O}$ values of dolomite from Silurian and Devonian formations vs. temperature. It also shows the $\delta^{18} \mathrm{O}$ values of formation fluids as related to the dolomite-water oxygen fractionation equation [82]. Isotopic compositions of fluid involved in the formation of RD2 in Silurian and Devonian formations show an overlap but Devonian RD2 shows slightly more enriched $\delta^{18} \mathrm{O}_{\text {SMOW }}$ likely related to the presence of more evolved basinal fluids (e.g., [77]) and a narrow range of temperature compared to the Silurian RD2. On the other hand, Saddle dolomite shows more enriched $\delta^{18} \mathrm{O}_{\text {SMOW }}$ and higher temperatures than the RD2 matrix dolomite. Considering the most negative $\delta^{18} \mathrm{O}$ value from Silurian RD2 (-7.96\% VPDB) and assuming a Silurian seawater value of $-3.5 \%$ o SMOW [83], results in a precipitation temperature of $56^{\circ} \mathrm{C}$, which is significantly lower than the average temperature obtained from fluid inclusion microthermometry $\left(89^{\circ} \mathrm{C}\right)$. Considering the most negative $\delta^{18} \mathrm{O}$ value from Devonian RD2 $(-7.66 \%$ o VPDB) and assuming a Devonian seawater value of $-2 \%$ sMOW [51], results in a precipitation temperature of $33{ }^{\circ} \mathrm{C}$, which also results significantly lower than the average temperature obtained from fluid inclusion microthermometry $\left(83^{\circ} \mathrm{C}\right)$. Thermal history reconstructions of the Michigan Basin have been carried out by many authors using different methods $[4,6,7,13,91,115,116]$. Considering the burial curve reconstructed by Zheng [7] the maximum burial temperature expected for Silurian formations would be ca. $63{ }^{\circ} \mathrm{C}$, assuming the atmospheric temperature of $20^{\circ} \mathrm{C}$, a thickness of $1700 \mathrm{~m}$ for the overlaying sedimentary cover and a geothermal gradient of $25^{\circ} \mathrm{C} / \mathrm{km}$. Recrystallization with the involvement of hydrothermal fluids (e.g., [5]) can be assumed considering the significantly higher (SD: $125^{\circ} \mathrm{C}$; RD2: $89^{\circ} \mathrm{C}$ ) temperature obtained from fluid inclusions microthermometric analysis. Considering the burial reconstruction proposed by Legall et al. [91] for Devonian formation using conodont and acritarch alteration index, the maximum burial temperature is estimated to be $60^{\circ} \mathrm{C}$, and hence, considerably lower than the temperatures obtained from fluid inclusions microthermometry. It follows that in both age groups, higher values of homogenization temperatures compared to those expected for maximum burial cannot be justified by the burial dolomitization model only [77] but must involve the presence of hydrothermal fluids [5,56].

Figure 21B shows the relationship between the measured $\delta^{18} \mathrm{O}$ values of late calcite cement (BKC) from Silurian and Devonian formations vs. temperature. It also shows the $\delta^{18} \mathrm{O}$ values of formation fluids as related to the calcite-water oxygen fractionation equation [117]. Isotopic compositions of fluid involved in the formation of BKC in Silurian and Devonian formations show an overlap. Devonian $\mathrm{BKC}$, however, shows slightly more enriched $\delta^{18} \mathrm{O}_{\mathrm{SMOW}}$ values compared to the Silurian BKC. This trend reflects a slight change in fluid chemistry in the two age groups that can be attributed to more evolved basinal fluids (e.g., [77]). 


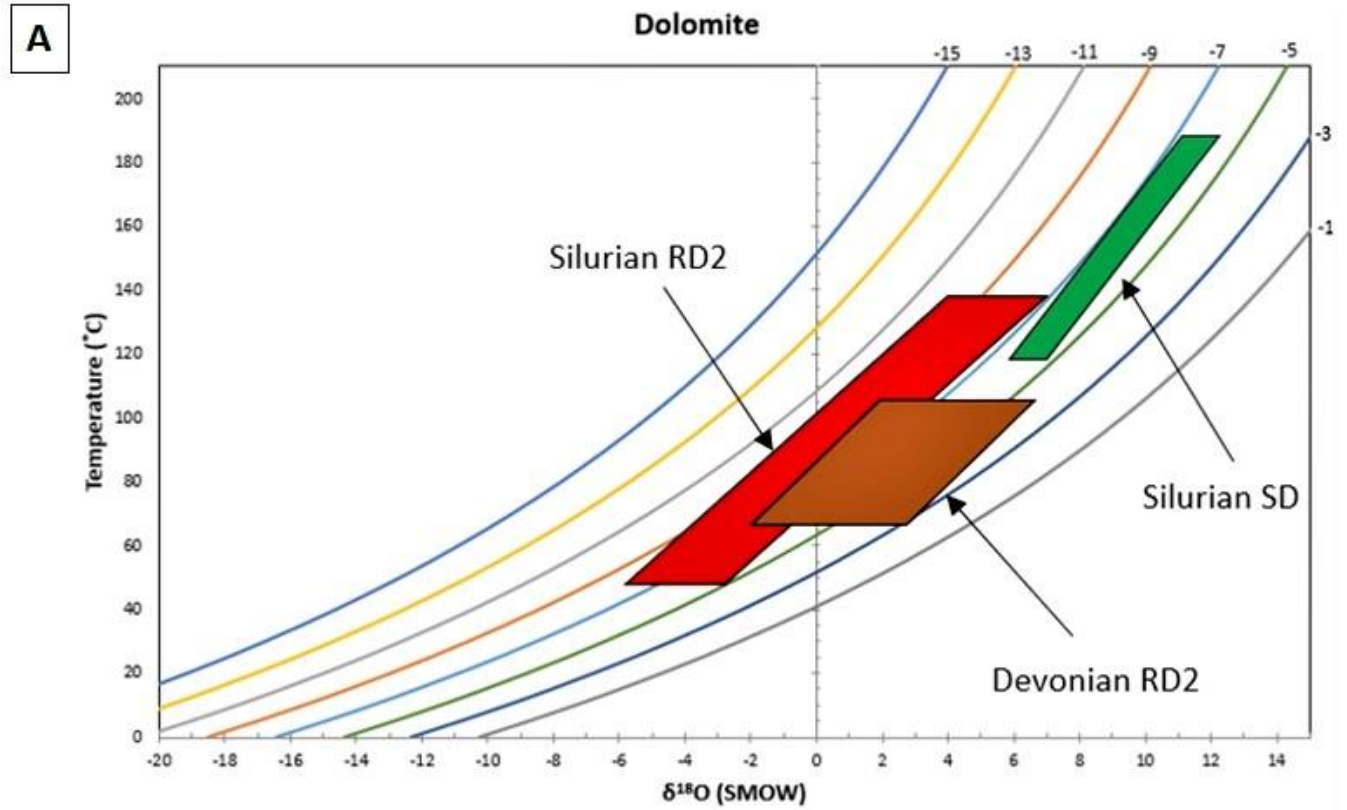

B

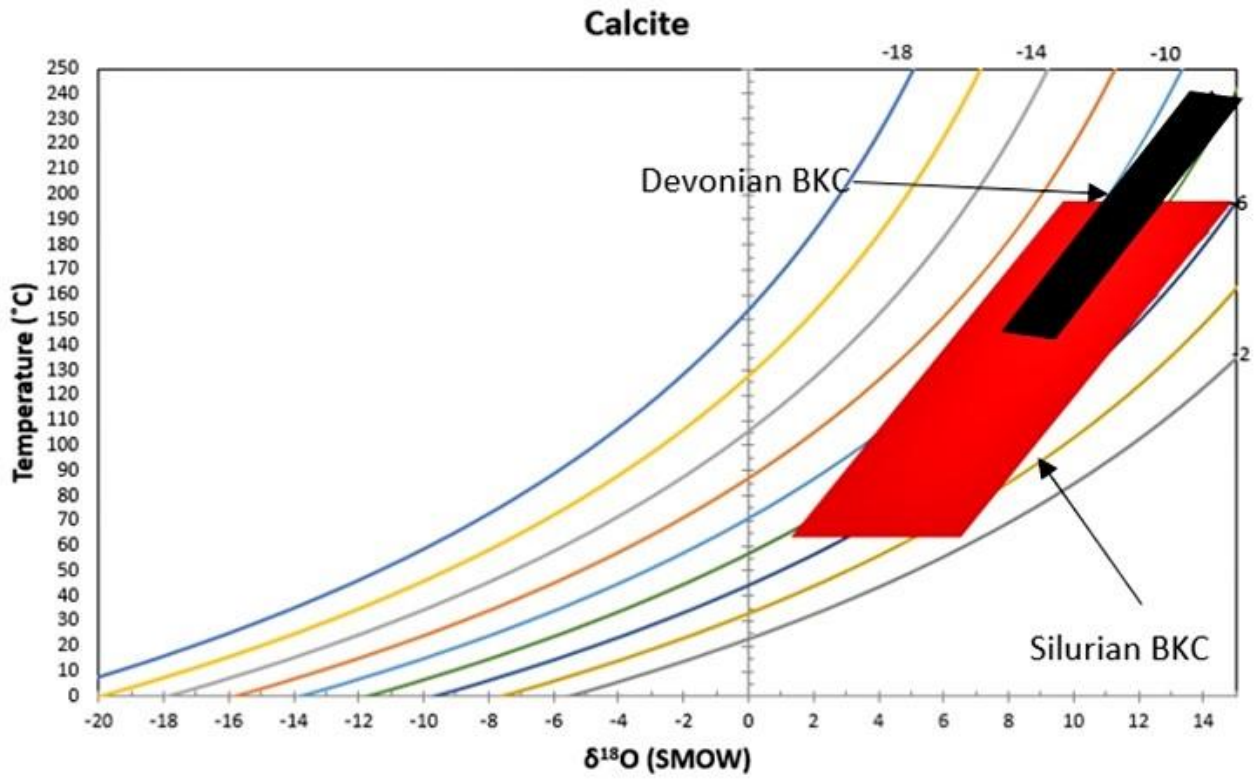

Figure 21. (A) Oxygen isotope values of dolomite from Silurian and Devonian formations plotted on the temperature-dependent, dolomite-water oxygen fractionation curve [82]. (B) Oxygen isotope values of calcite cement from Silurian and Devonian formations plotted on the temperature-dependent, calcite-water oxygen fractionation curve [117].

The fluid flow in intracratonic basins, such as the Michigan Basin, can be influenced by topography, compaction and convection related to density gradients (e.g., [118]).

The most likely fluid flow model, considering the low topographic relief and the carbonate rocks-dominated characteristic of the Michigan Basin, is the buoyancy-driven model related to temperature and density gradient [5]. Fractures and faults in sedimentary basins characterized by alternating carbonate rocks with variable permeability can promote the migration of cross-formational fluids [119]. In the Michigan Basin, faults and fracture systems in Paleozoic successions are controlled by the reactivation of basement structures and represent preferential pathways that promote fluid migration through low permeability sedimentary rocks such as shales and evaporites [5]. Homogenization temperatures of fluid inclusions hosted in dolomite samples from both Silurian and Devonian 
formations are significantly higher than temperatures estimated for maximum burial but lower than temperatures of fluid inclusions hosted in dolomites from previous studies carried out in the central part of the Michigan Basin (e.g., [13,91]). This evidence suggests that dolomite formation can be related to the presence of hydrothermal fluids that originated in the central part of the Michigan Basin migrated towards the margins [5]. The potential source of heat could be related to the reactivation of the buried mid-continental rift (MCR) during late Devonian to Mississippian time [120,121], while the preferential path for the migration of diagenetic fluids from the center of the Michigan Basin can be attributed to the Cambrian sandstones unconformably overlying the Precambrian basement [5,77]. Late calcite cement in sub-horizontal fractures near the base of the Silurian sequence dated in a recent study [120] show U-Pb ages of $318 \pm 10$ Ma determined by LA-ICP-MS and $313 \pm 1$ Ma by ID-TIMS. Hence, the authors suggest that the fluid flow of hydrothermal brines was influenced by the Alleghanian orogenies [120]. According to Sutcliff et al. [122] absolute dating of Cambrian and Silurian secondary minerals shows the same age and are contemporaneous with Alleghanian magmatism and uplift which caused the migration of hydrothermal fluids westwards from high-level Alleghanian plutons through the basal Cambrian.

\section{Conclusions}

Examination of cores, petrographic studies, microthermometric and geochemical analyses of Silurian and Devonian carbonates of the eastern side of the Michigan Basin (Huron Domain) led to the following conclusions regarding dolomitization and other related diagenetic processes observed in these successions:

- Silurian and Devonian formations are characterized by the presence of three types of replacive dolomite matrix RD1 (formed in shallow burial conditions), RD2 and RD3 (formed in intermediate burial conditions). In addition to these types, a coarse crystalline ferroan saddle dolomite cement (formed in intermediate burial conditions) filling fractures and vugs is observed only in the Silurian rocks. Early- and late-stage calcite cement have been distinguished in both groups of formations including isopachous, syntaxial overgrowth, dogtooth, drusy and blocky calcite.

- Isotopic data show an overlap between $\delta^{13} \mathrm{C}$ and $\delta^{18} \mathrm{O}$ values in Silurian and Devonian dolomites. In both Devonian and Silurian, many samples $\delta^{13} \mathrm{C}$ values fall in the range of values estimated for the marine dolomite of equivalent age. The negative shift in $\delta^{18} \mathrm{O}$ values, however, show evidence of dolomite recrystallization during burial and increasing temperature. Several other lines of evidence for recrystallization have been observed such as increasing crystal size, zonation, etched surfaces between cores and rims of crystals, and an increase in radiogenic strontium ratios.

- Silurian and Devonian Sr isotopic ratios show the seawater composition of their respective age as the primary source of diagenetic fluids with minor rock-water interactions. However, Silurian samples show a more radiogenic signature that documents more intense interactions of water with feldspar-bearing rocks

- REE shale-normalized patterns suggest that in both age groups the diagenetic fluids were originally of coeval seawater composition subsequently modified via water-rock interaction. The different evolution of the diagenetic fluids is more prominent in $\mathrm{REE}_{\mathrm{SN}}$ patterns from Silurian samples and it is possibly related to brines, which were modified by the dissolution of Silurian evaporites from the Salina series.

- Homogenization temperatures characterizing fluid inclusions hosted in RD2 from the Devonian samples, and RD2 and saddle dolomite in the Silurian successions exceed the temperature estimated for maximum burial. Hence, it may suggest the involvement of hydrothermal fluids during their formation.

- The potential source of heat could be related to the reactivation of the buried mid-continental rift (MCR), whereas the preferential path for the migration of diagenetic fluids from the central part of the Michigan Basin towards the margins via faults and fractures can be attributed to the Cambrian 
sandstones unconformably overlying the Precambrian basement that could have behaved as regional aquifers.

- Geochemical and fluid inclusion investigations denote two distinct fluid systems related to the diagenetic and tectonic history of Michigan Basin.

Author Contributions: Conceptualization, M.T.; writing—original draft preparation, M.T.; supervision, I.S.A.-A.; writing-review and editing, I.S.A-A.; review and editing, R.C. All authors have read and agreed to the published version of the manuscript.

Funding: Funding for this research was provided by NWMO to I.S.A.-A.

Acknowledgments: M.T. and I.S.A.-A. acknowledge the help from M. Price during isotope analysis. The critical review by $\mathrm{M}$. Hobbs is greatly appreciated. The anonymous reviewers are also acknowledged for their improvements to the paper.

Conflicts of Interest: The authors declare no conflict of interest.

\section{References}

1. Cercone, K.R.; Lohmann, K.C. Late burial diagenesis of Niagaran (Middle Silurian) pinnacle reefs in Michigan Basin. Am. Assoc. Geol. Bull. 1987, 71, 156-166.

2. Hamilton, G.D. Styles of reservoir development in middle Devonian carbonates of southwestern Ontario. In Diagenetic History of Ordovician and Devonian Oil and Gas Reservoirs in Southwestern Ontario; Open File Report 5822; Coniglio, M., Frape, S.K., Eds.; Ontario Geological Survey: Sudbury, ON, Canada, 1991.

3. Hamilton, D.G.; Coniglio, M. Reservoir development in the middle Devonian of southwestern Ontario. In Proceedings of the Ontario Petroleum Institute Thirty-First Annual Conference, Niagara Falls, ON, Canada, 28-30 October 1992; Technical Paper No. 9. Volume 32, p. 20.

4. Coniglio, M.; Sherlock, R.; Williams-Jones, A.E.; Middleton, K.; Frape, S.K. Burial and hydrothermal diagenesis of Ordovician carbonates from the Michigan Basin, Ontario, Canada. Int. Assoc. Sedimentol. 1994, $21,231-254$.

5. Haeri-Ardakani, O.; Al-Aasm, I.S.; Coniglio, M. Fracture mineralization and fluid flow evolution: An example from Ordovician-Devonian carbonates, southwestern Ontario, Canada. Geofluids 2013, 13, 1-20. [CrossRef]

6. Cercone, K.R. Evaporative sea-level drawdown in the Silurian Michigan Basin. Geology 1988, 16, $109-130$. [CrossRef]

7. Zheng, Q. Carbonate Diagenesis and Porosity Evolution in the Guelph Formation, Southwestern Ontario. Ph.D. Thesis, University of Waterloo, Waterloo, ON, Canada, 1999.

8. Coniglio, M.; Zheng, Q.; Carter, T.R. Dolomitization and recrystallization of middle Silurian reefs and platformal carbonates of the Guelph formation, Michigan basin, Southwestern Ontario. Bull. Can. Pet. Geol. 2003, 51, 177-199. [CrossRef]

9. Coniglio, M.; William-Jones, A.E. Diagenesis of Ordovician carbonates from the northeast Michigan Basin, Manitoulin island area, Ontario: Evidence from petrography, stable isotopes and fluid inclusions. Sedimentology 1992, 39, 813-836. [CrossRef]

10. Sanford, B.V.; Thompson, F.J.; McFall, G.H. Plate tectonics-A possible controlling mechanism in the development of hydrocarbon traps in southwestern Ontario. Bull. Can. Pet. Geol. 1985, 33, 52-71.

11. Carter, T.R.; Trevail, R.A.; Easton, R.M. Basement controls on some hydrocarbon traps in southern Ontario, Canada. In Basement and Basins of Eastern North America; Van der Pluijm, B.A., Catacosinos, P.A., Eds.; Geological Society of America: Boulder, CO, USA, 1996; Volume 308, pp. 95-107.

12. Boyce, J.J.; Morris, W.A. Basement-controlled faulting of Paleozoic strata in southern Ontario, Canada: New evidence from geophysical lineament mapping. Tectonophysics 2002, 353, 151-171. [CrossRef]

13. Luczaj, J.A. Evidence against the Dorag (mixing-zone) model for dolomitization along the Wisconsin arch-A case for hydrothermal diagenesis. Am. Assoc. Pet. Geol. Bull. 2006, 90, 1719-1738. [CrossRef]

14. Carter, T.R.; Easton, R.M. Extension of Grenville basement beneath southwestern Ontario: lithology and tectonic subdivisions. In Subsurface Geology of Southwestern Ontario: A Core Workshop; Ontario Petroleum Institute: London, ON, Canada, 1990.

15. Armstrong, D.K.; Carter, T.R. An updated guide to the subsurface Paleozoic stratigraphy of Southern Ontario. Ont. Geol. Surv. 2006, 6191, 214. 
16. Ontario Geological Survey. Bedrock geology of Ontario, southern sheet, Map 2544, scale 1:1 000 000; Ontario Geological Survey: Sudbury, ON, Canada, 1991.

17. Ontario Power Generation's (OPG). Deep Geologic Repository for Low and Intermediate Level Waste: Preliminary Safety Report; OPG: Thunder Bay, ON, Canada, 2011; Program Document n 00216-SR-01320-00001.

18. Johnson, M.D.; Armstrong, D.K.; Sanford, V.V.; Telford, P.G.; Rutka, M.A. Paleozoic and Mesozoic geology of Ontario, in geology of Ontario. Ont. Geol. Surv. 1992, 4, 907-1008.

19. De Klein, G.V.; Hsui, A.T. Origin of cratonic basins. Geology 1987, 15, 1094-1098. [CrossRef]

20. Sleep, N.H. Thermal effects of the formation of Atlantic continental margins by continental break up. Geophys. J. R. Astron. Soc. 1971, 24, 325-350. [CrossRef]

21. Sleep, N.H.; Snell, N.S. Thermal contraction and flexure of mid-continent and Atlantic marginal basins. Geophys. J. R. Astron. Soc. 1976, 45, 125-154. [CrossRef]

22. Nunn, J.A.; Sleep, N.H.; Moore, W.E. Thermal subsidence and generation of hydrocarbon in Michigan Basin. AAPG Bull. 1984, 68, 296-315.

23. Howell, P.D.; van der Pluijm, B.A. Early history of the Michigan basin: Subsidence and Appalachian tectonics. Geology 1990, 18, 1195-1198. [CrossRef]

24. Howell, P.D.; van der Pluijm, B.A. Structural sequences and styles of subsidence in the Michigan basin. Geol. Soc. Am. Bull. 1999, 111, 974-991. [CrossRef]

25. AECOM. Regional Geology—Southern Ontario; Report for the Nuclear Waste Management Organization NWMO DGR-TR-2011-15 R000; AECOM Canada Ltd.: Calgary, AB, Canada; Itasca Consulting Canada Inc.: Sudbury, ON, Canada, 2011.

26. Coakley, B.J.; Nadon, C.; Wang, H.F. Spatial variations in tectonic subsidence during Tippecanoe I in the Michigan Basin. Basin Res. 1994, 6, 131-140. [CrossRef]

27. Coakley, B.; Gurnis, M. Far-field tilting of Laurentia during the Ordovician and constraints on the evolution of a slab under an ancient continent. J. Geophys. Res. Solid Earth 1995, 100, 6313-6327. [CrossRef]

28. Beaumont, C.; Quinlan, G.; Hamilton, J. Orogeny and stratigraphy: Numerical models of the Paleozoic in the eastern interior of North America. Tectonics 1988, 7, 389-416. [CrossRef]

29. Bethke, C.M.; Marshak, S. Brine migrations across North America-The plate tectonics of groundwater. Annu. Rev. Earth Planet. Sci. 1990, 18, 287-315. [CrossRef]

30. Wang, H.F.; Crowley, K.D.; Nadon, G.C. Thermal history of the Michigan basin from apatite fission-track analysis and vitrinite reflectance. In Basin Compartments and Seals; Ortoleva, P.J., Ed.; AAPG Memoir 61; American Association of Petroleum Geologists: Tusla, OK, USA, 1994.

31. Van der Voo, R. Paleozoic paleogeography of North America, Gondwana, and intervening displaced terranes: Comparison of paleomagnetism with paleoclimatology and biogeographical patterns. Geol. Soc. Am. Bull. 1988, 100, 311-324. [CrossRef]

32. Sonnenfeld, P.; Al-Aasm, I.S. The Salina evaporites in the Michigan basin. In Early Sedimentary Evolution of the Michigan Basin; Catacosinos, P.A., Daniels, P.A., Jr., Eds.; Geological Society of America: Boulder, CO, USA, 1991; Volume 256, pp. 139-153.

33. Birchard, M.C.; Rutka, M.A.; Brunton, F.R. Lithofacies and geochemistry of the Lucas Formation in the subsurface of Southwestern Ontario: A high purity limestone and Potential high purity dolostone resource. Ont. Geol. Surv. 2004, 6137, 57.

34. Armstrong, D.K.; Goodman, W.R. Stratigraphy and Depositional Environments of Niagaran Carbonates, Bruce Peninsula, Ontario; Field Trip No. 4 Guidebook; American Association of Petroleum Geologists, Eastern Section Meeting; Ontario Petroleum Institute: London, ON, Canada, 1990.

35. Dickson, J.A. Carbonate identification and genesis as revealed by staining. J. Sediment. Res. 1966, 36, 491-505.

36. Evamy, B.D. The application of a chemical staining technique to a study of dolomitization. J. Int. Assoc. Sedimentol. 1963, 2, 164-170. [CrossRef]

37. Al-Aasm, I.S.; Taylor, B.E.; South, B. Stable isotope analysis of multiple carbonate samples using selective acid extraction. Chem. Geol. 1990, 80, 119-125. [CrossRef]

38. Hall, D.L.; Sterner, S.M.; Bodnar, R.J. Freezing point depression of $\mathrm{NaCl}-\mathrm{KCl}-\mathrm{H}_{2} \mathrm{O}$ solutions. Econ. Geol. 1988, 83, 197-202. [CrossRef]

39. Bodnar, R.J. Revised equation and table for freezing point depressions of $\mathrm{H}_{2} \mathrm{O}$-salt solutions. Econ. Geol. 1992, 83, 197-202.

40. Roedder, E. Fluid inclusions. Mineral. Soc. Am. Rev. Mineral. Sediment. Petrol. 1984, 57, 967-975. 
41. Lawler, J.P.; Crawford, M.L. Stretching of fluid inclusions resulting from a low temperature microthermometric technique. Econ. Geol. 1983, 78, 527-529. [CrossRef]

42. Pourmand, A.; Dauphas, N.; Ireland, T.J. A novel extraction chromatography and MC-ICP-MS technique for rapid analysis of REE, Sc and Y: Revising CI-chondrite and Post-Archean Australian Shale (PAAS) abundances. Chem. Geol. 2012, 291, 38-54. [CrossRef]

43. Bau, M.; Dulski, P. Distribution of yttrium and rare-earth elements in the Penge and Kuruman iron-formations, Transvaal Supergroup, South Africa. Precambr. Res. 1996, 79, 37-55. [CrossRef]

44. Kucera, J.; Cempirek, J.; Dolnicek, Z.; Muchez, P.; Prochaska, W. Rare earth elements and yttrium geochemistry of dolomite from post-Variscan vein-type mineralization of the Nizky Jesenik and Upper Silesian Basins, Czech Republic. J. Geochem. Explor. 2009, 103, 69-79. [CrossRef]

45. Felitsyn, S.; Morad, S. REE patterns in latest Neoproterozoic-early Cambrian phosphate concretions and associated organic matter. Geochem. Geol. 2002, 187, 257-265. [CrossRef]

46. Tortola, M. Petrographic and Geochemical Attributes of Silurian and Devonian Dolomitized Formations in the Huron Domain, Michigan Basin. Electronic Theses and Dissertation. 2019. Available online: https://scholar.uwindsor.ca/etd/7740 (accessed on 13 September 2019).

47. Sibley, D.F.; Gregg, J.M. Classification of dolomite rock textures. J. Sediment. Res. 1987, 57, 967-975.

48. Middleton, K.; Coniglio, M.; Sherlock, R.; Frape, S.K. Dolomitization of Middle Ordovician carbonate reservoirs, southwestern Ontario. Bull. Can. Pet. Geol. 1993, 41, 150-163.

49. Hurley, N.F.; Lohmann, K.C. Diagenesis of Devonian reefal carbonates in the Oscar Range, Canning Basin, Western Australia. J. Sediment. Res. 1989, 59, 127-146.

50. Land, L.S. The origin of massive dolomite. J. Geol. Educ. 1985, 33, 112-125. [CrossRef]

51. Veizer, J.; Ala, D.; Azmy, K.; Bruckschen, P.; Buhl, D.; Bruhn, F.; Carden, G.A.F.; Diener, A.; Ebneth, S.; Godderis, Y.; et al. 87Sr/86Sr and $813 \mathrm{C}$ and $\delta 18 \mathrm{O}$ evolution of Phanerozoic seawater. Chem. Geol. 1999, 161, 59-88. [CrossRef]

52. Qing, H.; Barnes, C.R.; Buhul, D.; Veizer, J. The strontium isotopic composition of Ordovician and Silurian brachiopods and conodont: Relationships to geological events and implications for coeval seawater. Geochim. Cosmochim. Acta 1998, 62, 1721-1733. [CrossRef]

53. Boggs, S. Petrology of Sedimentary Rocks; Macmillan Publishing Company: New York, NY, USA, $1992 ;$ p. 707.

54. Azmy, K.; Brand, U.; Sylvester, P.; Gleeson, S.A.; Logan, A.; Bitner, M.A. Biogenic and abiogenic low-Mg calcite (bLMC and aLMC): Evaluation of seawater-REE composition, water masses and carbonate diagenesis. Chem. Geol. 2011, 280, 180-190. [CrossRef]

55. Gao, G.; Land, L.S. Early ordovician cool creel dolomite, middle Arbuckle group, silick Hills, SW Oklahoma, USA: Origin and modification. J. Sediment. Res. 1991, 61, 161-173.

56. Haeri-Ardakani, O.; Al-Aasm, I.S.; Coniglio, M. Petrologic and geochemical attributes of fracture-related dolomitization in Ordovician carbonates and their spatial distribution in southwestern Ontario, Canada. Mar. Pet. Geol. 2013, 3, 409-422. [CrossRef]

57. Gregg, J.M.; Sibley, D.F. Epigenetic dolomitization and the origin of xenotopic dolomite texture. J. Sediment. Res. 1984, 54, 908-931.

58. Gregg, J.M.; Shelton, K.L. Dolomitization and dolomite Neomorphism in the back-reef facies of the Bonneterre and Davis formations (Cambrian), southwestern Missouri. J. Sediment. Res. 1990, 60, 549-562.

59. Hiatt, E.E.; Pufahl, P.K. Cathodoluminescence petrography of carbonate rocks: Application to understanding diagenesis, reservoir quality, and pore system evolution. In Cathodoluminescence and Its Application to Geoscience; Short Course Series; Coulson, I.M., Ed.; Mineralogical Association of Canada: Québec, QC, Canada, 2014; Volume 45, pp. 75-96.

60. Dawans, J.M.; Swart, P.K. Textural and geochemical alteration in the late Cenozoic Bahamian dolomites. Sedimentology 1988, 35, 385-403. [CrossRef]

61. Land, L.S. Dolomitization of the Hope Gate Formation (north Jamaica) by seawater: Reassessment of mixing-zone dolomite. In Stable Isotope Geochemistry: A Tribute to Samuel; Geochem. Society: San Antonio, TX, USA, 1991.

62. Kupecz, J.A.; Land, L.S. Progressive recrystallization and stabilization of early-stage dolomite: Lower Ordovician Ellenburger Group, west Texas. In Dolomites. A Volume in Honor of Dolomieu; Purser, B., Tucker, M., Zenger, D., Eds.; International Association of Sedimentologists: Gent, Belgium, 1994; Volume 21, pp. 155-166. 
63. Sibley, D.F.; Gregg, G.M.; Brown, R.G.; Laudon, P.R. Dolomite crystal size distribution. In Carbonate Microfabrics, Frontiers in Sedimentology; Rezak, R., Lavoie, D.L., Eds.; Springer: New York, NY, USA, 1993; pp. 195-204.

64. Machel, H.G. Concepts and models of dolomitization: A critical reappraisal. In The Geometry and Petrogenesis of Dolomite Hydrocarbon Reservoirs; Braithwaite, C.J.R., Rizzi, G., Drake, G., Eds.; Geological Society Special Publication: London, UK, 2004; Volume 245, pp. 7-63.

65. Montanez, I.P.; Read, J.F. Fluid-rock interaction history during stabilization of early dolomites, Upper Knox Group (Lower Ordovician), U.S. Appalachian. J. Sediment. Res. 1992, 62, 753-778.

66. Machel, H.G. Recrystallization versus neomorphism, and the concept of "significant recrystallization" in dolomite research. Sediment. Geol. 1997, 113, 161-168. [CrossRef]

67. American Geological Institute (AGI). Glossary of Geology; AGI: Alexandria, VA, USA, 1987; p. 788.

68. Mazzullo, S.J. Geochemical and neomorphic alteration of dolomite: A review. Carbonate Evaporites 1992, 7 , 21-37. [CrossRef]

69. Al-Aasm, I.S. Chemical and isotopic constraints for recrystallization of sedimentary dolomites from the Western Canada Sedimentary basin. Aquat. Geochem. 2000, 6, 229-250. [CrossRef]

70. Al-Aasm, I.S.; Packard, J.J. Stabilization of early-formed dolomite: A tale of divergence from two Mississippian dolomites. Sediment. Geol. 2000, 131, 97-108. [CrossRef]

71. Adam, J.; Al-Aasm, I.S. Petrologic and geochemical attributes of calcite cementation, dolomitization and dolomite recrystallization: An example from the Mississippian Pekisko Formation, west-central Alberta. Bull. Can. Pet. Geol. 2017, 65, 235-261. [CrossRef]

72. Al-Aasm, I.S.; Lu, F. Multistage dolomitization of the Mississippian turner valley formation, quirk Creek field, alberta: Chemical and petrologic evidence. Can. Soc. Pet. Geol. 1994, 17, 657-675.

73. Qing, H.; Mountjoy, E.W. Rare element geochemistry of dolomite in the Middle Devonian Presqu'ile barrier, Western Canada Sedimentary Basin: Implication fluid-rock ratios during dolomitization. Sedimentology 1994, 41,787-804. [CrossRef]

74. Walker, K.R.; Jernigan, D.G.; Weber, L.J. Petrographic criteria for the recognition of marine, syntaxial overgrowths, and their distribution in geologic time. Carbonates Evaporites 1990, 5, 141-161. [CrossRef]

75. Choquette, P.W.; James, N.P. Diagenesis in limestones. The deep burial environment. Geosci. Can. 1987, 14, 3-35.

76. Flügel, E. Microfacies of Carbonate Rocks, Analysis, Interpretation and Application; Springer: Berlin, Germany, 2010; p. 976.

77. Al-Aasm, I.S.; Crowe, R. Fluid compartmentalization and dolomitization in the Cambrian and Ordovician successions of the Huron Domain, Michigan Basin. Mar. Pet. Geol. 2018, 92, 160-178. [CrossRef]

78. Reinhold, C. Dog-tooth cements; indicators of different diagenetic environments. Zbl. Geol. Paläont. 1999, 10, 1221-1235.

79. Land, L.S. The isotopic and trace element geochemistry of dolomite: The state of the art. In Concepts and Models of Dolomitization; Zenger, D.H., Dunham, J.B., Ethington, R.L., Eds.; SEPM Special Publication: Broken Arrow, UK, USA, 1980; Volume 28, pp. 87-110.

80. Allan, J.R.; Wiggins, W.D. Dolomite Reservoirs: Geochemical Techniques for Evaluating Origin and Distribution; Continuing Education Course Note Series \#36; American Association of Petroleum Geologists: Tulsa, OK, USA, 1993.

81. Al-Aasm, I.S. Origin and characterization of hydrothermal dolomite in the Western Canada Sedimentary Basin: Jour. Geochem. Explor. 2003, 78-79, 9-15. [CrossRef]

82. Land, L.S. The application of stable isotopes to studies of the origin of dolomite and to problems of diagenesis of clastic sediments. In Stable Isotopes in Sedimentary Geology; Society of Economic Paleontologists and Mineralogists: New York, NY, USA, 1983; p. 129.

83. Azmy, K.; Veizer, J.; Bassett, M.G.; Copper, P. Oxygen and carbon isotopic composition of Silurian brachiopods: Implications for coeval seawater and glaciations. Geol. Soc. Am. Bull. 1998, 110, 1499-1512. [CrossRef]

84. Baldermann, A.; Deditius, A.P.; Dietzel, M.; Fichtner, V.; Fischer, C.; Hippler, D.A.; Leis, A.; Baldermann, C.; Mavromatis, V.; Stickler, C.P.; et al. The role of bacterial sulfate reduction during dolomite precipitation: Implications from Upper Jurassic platform carbonates. Chem. Geol. 2015, 412, 1-14. [CrossRef]

85. Warren, J. Dolomite: Occurrence, evolution and economically important associations. Earth Sci. Rev. 2000, 1-3, 1-81. [CrossRef] 
86. Dorobek, S.L.; Smith, T.M.; Whitsit, P.M. Microfabrics and geochemistry of meteorically altered dolomite in Devonian and Mississippian carbonates, Montana and Idaho. In Carbonate Microfabrics; Rezak, R., Lavoie, D.L., Eds.; Springer: Berlin, Germany, 1993; Volume 16, pp. 205-224.

87. Durocher, S.; Al-Aasm, I.S. Dolomitization and neomorphism of Mississippian (Visean) upper Debolt Formation, Blueberry Field, NE British Columbia, Canada: Geologic, petrologic and chemical evidence. Am. Assoc. Pet. Geol. Bull. 1997, 81, 954-977.

88. Geldern, R.A.; Joachimski, M.M.; Day, J.; Jansen, U.; Alvarez, F.; Yolkin, E.A.; Ma, X.P. Carbon, oxygen and strontium isotope records of Devonian brachiopod shell calcite. Palaeogeogr. Palaeoclimatol. Palaeoecol. 2006, 240, 47-67. [CrossRef]

89. Worthington, S.R.H. Karst Assessment; NWMO DGR-TR-2011-22; Canadian Nuclear Safety Commission: Toronto, ON, Canada, 2011.

90. Barnes, D.A.; Parris, T.M.; Grammer, G.M. Hydrothermal Dolomitization of Fluid Reservoirs in the Michigan Basin, USA; Search and Discovery Article \#50087; AAPG/Datapages, Inc.: San Antonio, TX, USA, 2008.

91. Legall, F.D.; Barnes, C.R.; Macqueen, R.W. Thermal maturation, burial history and hotspot development, Paleozoic strata of southern Ontario-Quebec, from conodont and acritach color alteration index. Bull. Can. Pet. Geol. 1981, 29, 492-539.

92. Sibley, D.F. Unstable to stable transformations during dolomitization. J. Geol. 1990, 98, 967-975. [CrossRef]

93. Gregg, J.M.; Howard, S.A.; Mazzullo, S.J. Early diagenetic recrystallization of Holocene (<3000 years old) peritidal dolomites, Ambergris Cay, Belize. Sedimentology 1992, 39, 143-160. [CrossRef]

94. White, T.; Al-Aasm, I.S. Hydrothermal dolomitization of the Mississippian Upper Debolt Formation, Sikanni gas field, northeastern British Columbia, Canada. Bull. Can. Pet. Geol. 1997, 45, 297-316.

95. Malone, M.J.; Baker, P.A.; Burns, S.J. Recrystallization of dolomite: An experimental study from 50-200 ${ }^{\circ} \mathrm{C}$. Geochim. Cosmochim. Acta 1996, 60, 2189-2207. [CrossRef]

96. Swart, P.K. The geochemistry of carbonate diagenesis: The past, present and future. Int. Assoc. Sedimentol. 2015, 62, 1233-1304. [CrossRef]

97. Veizer, J. Chemical diagenesis of carbonates: Theory and application of trace element technique. In Stable Isotopes in Sedimentary Petrology; Arthur, M.A., Anderson, T.F., Kaplan, I.R., Veizer, J., Land, L.S., Eds.; Society of Economic Paleontologists and Mineralogists: New York, NY, USA, 1983; Volume 10, pp. 3-100.

98. Gao, G. Geochemical and isotopic constraints on the diagenetic history of a massive, late Cambrian (Royer) dolomite, Lower Arbukle Group, Silick Hills, SW Oklahoma, USA. Geochim. Cosmochim. Acta 1990, 54, 1979-1989. [CrossRef]

99. Frank, J.R. Dolomitization in the Taum Sauk Limestone (Upper Cambrian), southeast Missouri. J. Sediment. Res. 1981, 51, 7-18.

100. Lorens, R.B.; Mn, S.C. Distribution coefficients in calcite as a function of calcite precipitation rate. Geochim. Cosmochim. Acta 1981, 45, 553-561. [CrossRef]

101. Machel, H.G.; Anderson, J.H. Pervasive subsurface dolomitization of the Nisku Formation in central Alberta. J. Sediment. Res. 1989, 59, 891-911.

102. Banner, J.L. Application of the trace element and isotope geochemistry of strontium to studies of carbonate diagenesis. Sedimentology 1995, 42, 805-824. [CrossRef]

103. Dunham, J.B.; Olson, E.R. Shallow subsurface dolomitizaion of subtidally deposited carbonate sediments in the Hanson Creek Formation (Ordovician-Silurian) of Central Nevada. In Concepts and Models of Dolomitization; Zenger, D.H., Dunham, J.B., Ethington, R.L., Eds.; Society of Economic Paleontologists and Mineralogists: New York, NY, USA, 1980; Volume 28, pp. 139-161.

104. Webb, G.E.; Nothdurft, L.D.; Kamber, B.S.; Kloprogge, J.T.; Zhao, J.X. Rare earth element geochemistry of scleractinian coral skeleton during meteoric diagenesis: A before and-after sequence through neomorphism of aragonite to calcite. Sedimentology 2009, 56, 1433-1463. [CrossRef]

105. Allwood, A.C.; Kamber, B.S.; Walter, M.R.; Burch, I.W.; Kanik, I. Trace elements record depositional history of an Early Archean stromatolitic carbonate platform. Chem. Geol. 2010, 270, 148-163. [CrossRef]

106. Banner, J.L.; Hanson, G.N.; Meyers, W.J. Rare earth element and Nd isotopic variations in regionally extensive dolomites from the Burlington-keokuk formation (Mississippian): Implications for REE mobility during carbonate diagenesis. J. Sediment. Res. 1988, 58, 415-432.

107. Frimmel, H.E. Trace element distribution in Neoproterozoic carbonates as palaeoenvironmental indicator. Chem. Geol. 2009, 258, 338-353. [CrossRef] 
108. Zhao, Y.; Zheng, Y.F.; Chen, F. Trace element and strontium isotope constraints on sedimentary environment of Ediacaran carbonates in southern Anhui, South China. Chem. Geol. 2009, 265, 345-362. [CrossRef]

109. Chaudhuri, S.; Clauer, N. (Eds.) Isotopic Signatures and Sedimentary Records; Lecture Notes in Earth Sciences; Springer: Berlin, Germany, 1992; Volume 43, pp. 497-529.

110. Murray, R.W.; Buchholtz ten Brink, M.R.; Gerlach, D.C.; Russ, P.G., III; Jones, D.L. Interoceanic variation in the rare earth, major, and trace element depositional chemistry of chert: Perspectives gained from the DSDP and ODP record. Geochim. Cosmochim. Acta 1992, 56, 1897-1913. [CrossRef]

111. Madhavaraju, J.; Ramasamy, S. Rare earth elements in limestones of Kallankurichchi formation of Ariyalur Group, Tiruchirapalli Cretaceous, Tamil Nadu. J. Geol. Soc. India 1999, 54, 291-301.

112. De Baar, H.J.W. On cerium anomalies in the Sargasso Sea. Geochim. Cosmochim. Acta 1991, 55, $2981-2983$. [CrossRef]

113. Nothdurft, L.D.; Webb, G.E.; Kamber, B.S. Rare earth element geochemistry of Late Devonian reefal carbonates, Canning Basin, Western Australia: Confirmation of a seawater REE proxy in ancient limestones. Geochim. Cosmochim. Acta 2004, 68, 263-283. [CrossRef]

114. Tostevin, R.; Shields, G.A.; Tarbuck, G.M.; He, T.; Clarkson, M.O.; Wood, R.A. Effective use of cerium anomalies as a redox proxy in carbonate-dominated marine settings. Chem. Geol. 2016, 438, 146-162. [CrossRef]

115. Vugrinovich, R. Shale compaction in the Michigan Basin: Estimates of former depth of burial and implications for paleogeothermal gradients. Bull. Can. Pet. Geol. 1988, 36, 1-8.

116. Cercone, K.R.; Pollack, H.N. Thermal maturity of the Michigan Basin. In Early Sedimentary Evolution of the Michigan Basin; Catacosinos, P., Daniels, P., Eds.; Geological Society of America: Boulder, CO, USA, 1991; Special Paper 256; pp. 1-11.

117. Friedman, I.; $\mathrm{O}^{\prime}$ Neil, J.R. Compilation of stable isotope fractionation factors of geochemical interest. In Data of Geochemistry, 6th ed.; Chapter, K.K., Ed.; U.S. Government Printing Office: Washington, DC, USA, 1977.

118. Graven, G. Continental-scale groundwater flow and geological processes. Annu. Rev. Earth Planet. Sci. 1995, 23, 89-118. [CrossRef]

119. Bjorlykke, K. Fluid-flow processes and diagenesis in sedimentary basins. In Geofluids: Origin, Migration and Evolution of Fluids in Sedimentary Basins; Parnell, J., Ed.; Geological Society: London, UK, 1994; Volume 87, pp. 127-140.

120. Girard, J.P.; Barnes, D.A. Illitization and paleothermal regimes in the middle Ordovician St. Peter sandstone, central Michigan Basin: K-Ar, oxygen isotope, and fluid inclusion data. Am. Assoc. Pet. Geol. Bull. 1995, 79, 49-69.

121. Ma, L.; Castro, M.C.; Hall, C.M. Atmospheric noble gas signatures in deep Michigan Basin brines as indicators of a past thermal event. Earth Planet. Sci. Lett. 2009, 277, 137-147. [CrossRef]

122. Sutcliffe, C.N.; Thibodeau, A.M.; Davis, D.W.; Al-Aasm, I.S.; Parmenter, A.; Zajacz, Z.; Jensen, M. Hydrochronology of a proposed deep geological repository for Low and Intermediate nuclear waste in southern Ontario from $\mathrm{U}-\mathrm{Pb}$ dating of secondary minerals: Response to Alleghanian events. Can. J. Earth Sci. 2019. [CrossRef]

(C) 2020 by the authors. Licensee MDPI, Basel, Switzerland. This article is an open access article distributed under the terms and conditions of the Creative Commons Attribution (CC BY) license (http://creativecommons.org/licenses/by/4.0/). 